Late Cenozoic Stratigraphic Units, Northeastern San Joaquin Valley, California

GE O LO GI CA L S UR V EX B UL LE TI N 1470 39092042132144

metadc958042 



\section{Late Cenozoic Stratigraphic Units, Northeastern San Joaquin Valley, California}

By DENIS E. MARCHAND and ALAN ALI.WARDT

GE OLOGICA L S UR VEY B ULLE TIN 1470

I'NITED STATES GOYERNMENT PRINIING OFFICE, WASHINGTON : 1981 


\section{UNITED STATES DEPARTMENT OF THE INTERIOR}

CECIL D. ANDRUS, Secretary

\section{GEOLOGICAL SURVEY}

H. William Menard, Director

Library of Congress Cataloging in Publication Data

Marchand, Denis E.

Late Cenozoic stratigraphic units, northeastern San Joaquin Valley, California

Geological Survey Bulletin 1470 Bibliography: p. 67-70.

Supt. of Docs. no.: I 19.3:1470

1. Geology, Stratigraphic--Cenozoic. 2. Geology-California--San Joaquin Valley. I. Allwardt, Alan joint author. II. Title. III. Series: United States. Geological Survey. Bulletin. 1470.

QE75.B9 no. 1470 (QE690) 557.3s (551.7'8) 80-60716

For sale by the Superintendent of Documents, U. S. Government Printing Office Washington, D. C. 20402 


\section{CONTENTS}

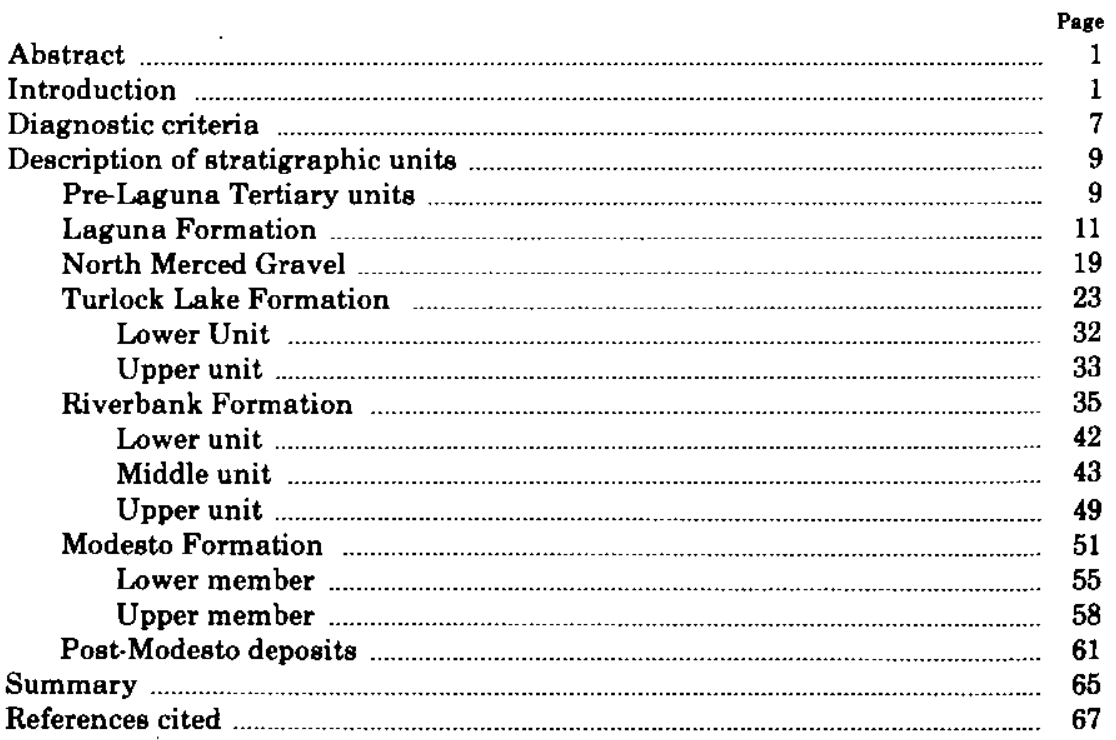

\section{ILLUSTRATIONS}

Plate 1. Generalized geologic map of the Merced-Madera area, northeastern San Joaquin Valley, California ........................ In pocket

2. Geologic map of the Snelling area and the area near the confluence of the Merced and San Joaquin Rivers, Merced County, California

In pocket

FIgURE 1. Map of northeastern San Joaquin Valley showing areas mapped in detail and locations of type and reference sections of late Cenozoic units

2. Correlation chart showing relation of proposed stratigraphic units to those previously used in the northeastern San Joaquin Valley

3. Schematic geologic section across the Merced River near Snelling, Merced County, showing relation of soils to stratigraphic units and geomorphic surfaces

4. Schematic geologic section across the Merced River west of Stevinson, Merced County, showing relation of soils to Modesto and post-Modesto deposits and geomorphic surfaces 


\section{TABLES}

TABLE 1. Regional strike, thickness, and gradient of reconstructed depositional surfaces for some Cenozoic units in the northeastern San Joaquin Valley

2. Comparison of some age-diagnostic soils, northeastern San Joaquin Valley

4

3. Comparison of some characteristics of three units in the Riverbank Formation 


\title{
LATE CENOZOIC STRATIGRAPHIC UNITS, NORTHEASTERN SAN JOAQUIN VALLEY, CALIFORNIA
}

\author{
By Denis E. MARCHAND and ALAN ALLWARDT
}

\begin{abstract}
Recent mapping of late Tertiary and Quaternary deposits in the northeastern San Joaquin Valley has shown the need for clarification, revision, and subdivision of some of the previously mapped stratigraphic units. We propose a uniform nomenclature for deposits younger than the Mehrten Formation in this region. The Laguna Formation (late Pliocene) is now recognized as far south as the Merced area, where it is overlain by the North Merced Gravel (Pliocene or Pleistocene). The China Hat pediment of Hudson (Geol. Soc. America Bull., 1960, v. 71, p. 1552) is interpreted as the uppermost gravel member of the Laguna Formation and is believed to represent an old fan deposit rather than a pediment. The Laguna, Turlock Lake, Riverbank, and Modesto Formations are lithologically similar but may be distinguished and subdivided on the basis of soil profile development, topographic position and expression, local lithologic differences, and unconformities associated with buried soils. The Laguna and Turlock Lake Formations are each subdivided into two informally named units (lower, upper), and the Riverbank Formation is subdivided into three units (lower, middle, upper), all separated by unconformities and welldeveloped buried soils. The Modesto Formation is subdivided into two informally designated members, separated by a minor unconformity and a weakly to moderately developed buried soil. The lower (older) member of the Modesto is in places associated with two geomorphic surfaces, and as many as four terraces showing slightly different soil development are associated with deposits of the upper (younger) member. Post-Modesto deposits are subdivided into four stratigraphic units, informally designated post-Modesto I, II, III, and IV. Most of the stratigraphic units discussed are believed to represent separate alluvial episodes, recorded by fill terraces opening westward onto alluvial fans. Substantial time intervals between periods of aggradation are represented by buried paleosols. Some of the properties of relict and buried paleosols are summarized, and their relations to the proposed stratigraphic units are described.
\end{abstract}

\section{INTRODUCTION}

The thick sequence of late Cenozoic surficial deposits that underlies the entire San Joaquin Valley of California has been studied in detail only in the northeastern San Joaquin Valley. The first important differentiation of late Cenozoic units in the northeastern part of the valley was by Gale, Piper, and Thomas (1939), who distinguished three major deposits in the Mokelumne area: the 
Laguna Formation, the Arroyo Seco Gravel, and the Victor Formation. Subsequently Arkley $(1954,1962 a)$ reported a sequence of major Pleistocene alluvial deposits in the vicinity of the Merced River. Being a soil scientist, he made no attempt to assign formational names to the deposits in the earlier report. Davis and Hall (1959), after consulting Arkley's work, designated three of these deposits the Turlock Lake, Riverbank, and Modesto Formations. More recently, late Cenozoic deposits have been studied in some detail along the upper San Joaquin River by Janda (1965, 1966), along the Chowchilla River by Helley (1967), and along the Mokelumne and American River drainages by Shlemon (1967a, 1967b, 1971, 1972). Detailed soil survey mapping has been completed over the entire area (Arkley, 1954, 1962b, 1964; Ulrich and Stromberg, 1962; Huntington, 1971). The high quality of soil survey mapping has permitted the differentiation and detailed mapping of many Quaternary units (Marchand, 1976a-f) that would otherwise have been lumped together with other units. The spatial distribution of and stratigraphic relations between these units have in turn allowed a more complete reconstruction of the Quaternary depositional, tectonic, and climatic history of central California (Marchand, 1976g, 1977).

Recent geologic mapping in the northeastern San Joaquin Valley has shown the need to clarify, revise, and subdivide some previously named stratigraphic units. This report proposes a uniform stratigraphic nomenclature for continental deposits younger than the Mehrten Formation in the northeastern San Joaquin Valley. Its emphasis is therefore on description rather than interpretation. This report is based on studies in eastern Stanislaus, Merced, and Madera Counties and in northern Fresno County (fig. 1), but reconnaissance investigations suggest that the proposed stratigraphic units apply, with some local modification, throughout most of the eastern San Joaquin Valley and southeastern Sacramento Valley. The Laguna Formation and the North Merced Gravel are described as they occur in the study area. Type

FIGURE 1.-Areas mapped in detail (dashed outlines) and locations of type and reference sections discussed in test (numbered localities). 1, reference section A, Laguna Formation and type section, North Merced Gravel; 2, reference section B, Laguna Formation; 3, Main Canal cut, China Hat Gravel Member of Laguna Formation; 4, type section, Turlock Lake Formation; 5, reference section A, Turlock Lake Formation; 6, reference section B, Turlock Lake Formation; 7, type section and reference section A, Riverbank Formation; 8, reference section B, Riverbank Formation; 9, reference section C, Riverbank Formation; 10, reference section D, Riverbank Formation; 11, type section, Modesto Formation. 
sections of the Turlock Lake, Riverbank, and Modesto Formations are redescribed, some additional reference sections are provided, and post-Modesto deposits are discussed. The relation of proposed

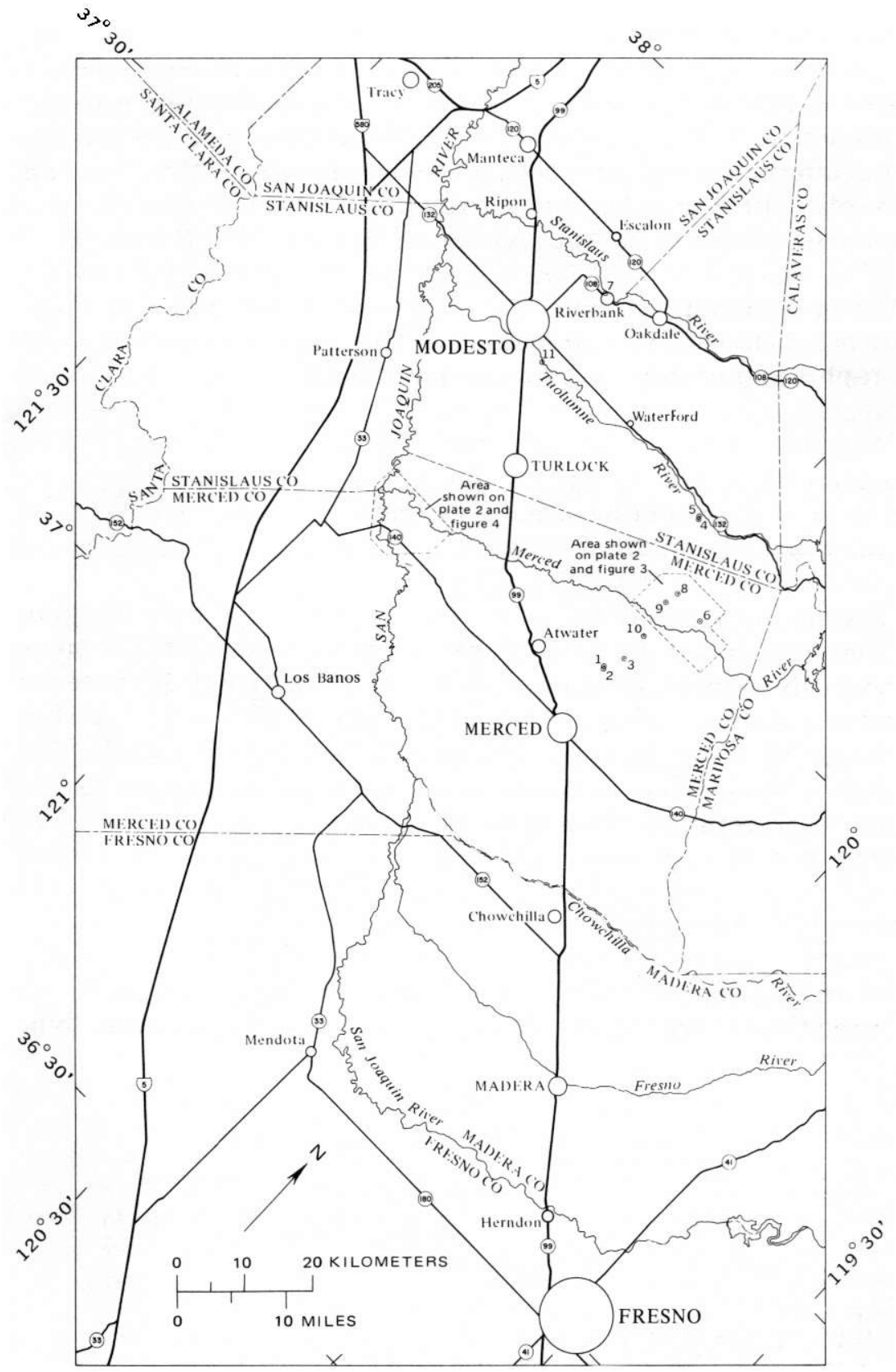


stratigraphic units to those previously used is shown in figure 2. Table 1 summarizes the regional strike, thickness, and depositional surface gradients of some Cenozoic units in the northeastern San Joaquin Valley; these data are discussed below and in the final section of this report.

A secondary objective is to indicate some of the characteristics of stratigraphically important soils in this region and their use in the development of a Quaternary chronology. More detailed soil data and interpretations have been presented elsewhere (Marchand and Harden, 1976; Harden and Marchand, 1977). Soil nomenclature follows the Seventh Approximation System (Soil Survey Staff, 1975) as used by Birkeland (1974, p.3-10), although Great Soil Group designations from the older system are given in parentheses. Some selected properties of age-diagnostic soils of stratigraphic importance are compared in table 2.

TABLE 1.-Comparison of approximate regional gradient, ${ }^{1}$ strike, ${ }^{\prime}$ and thickness of some Cenozoic units, northeastern San Joaquin Valley

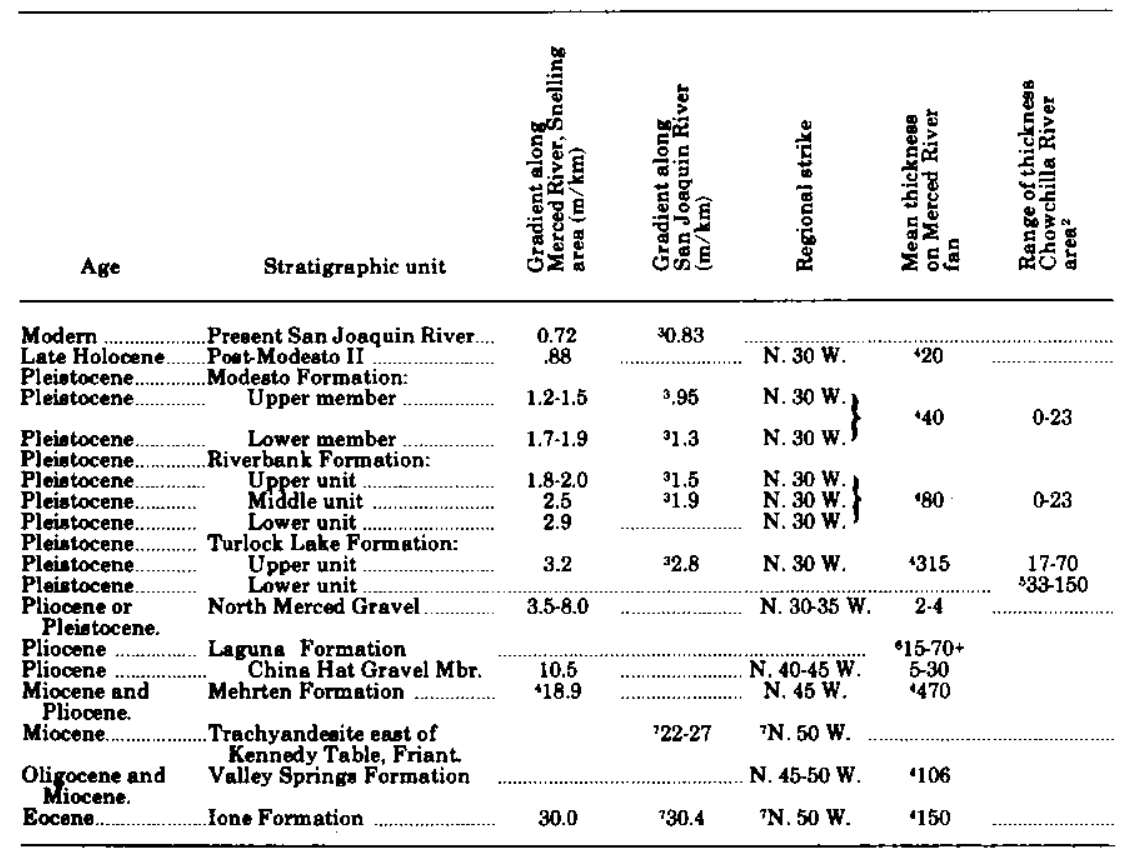

'Based on generalized contoura on reconstructed eurface of unit.

After Helley (1967, fig. 39).

After Janda (1965, pl. 5).

After Arkley (1962a).

- May aloo include Laquna Formation.

Includes Chine Hat Gravel Member.

iN. King Huber (written commun., 1977). 


\begin{tabular}{|c|c|c|c|c|c|c|c|c|c|c|}
\hline \multirow{2}{*}{\multicolumn{2}{|c|}{ Age }} & $\begin{array}{c}\text { Gale and others } \\
(1939)\end{array}$ & $\begin{array}{c}\text { Davis and Hall } \\
(1959)\end{array}$ & Arkley (1962a) & \multicolumn{3}{|c|}{ Janda (1965) } & \multicolumn{3}{|c|}{ This report } \\
\hline & & $\begin{array}{c}\text { Mokelumne } \\
\text { River } \\
\text { area }\end{array}$ & $\begin{array}{c}\text { Eastern } \\
\text { Stanislaus } \\
\text { and northern } \\
\text { Merced Counties }\end{array}$ & $\begin{array}{l}\text { Merced } \\
\text { River } \\
\text { area }\end{array}$ & \multicolumn{3}{|c|}{ San Joaquin River fan } & \multicolumn{3}{|c|}{ Northeastern San Joaquin Valley } \\
\hline \multirow{4}{*}{ 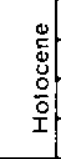 } & Modern & \multirow{4}{*}{$\begin{array}{l}\text { Recent } \\
\text { alluvium }\end{array}$} & \multirow{4}{*}{$\begin{array}{l}\text { Recent } \\
\text { alluvium, } \\
\text { sand dunes }\end{array}$} & \multirow{4}{*}{$\begin{array}{l}\text { Recent } \\
\text { alluvium, } \\
\text { sand dunes }\end{array}$} & \multirow{4}{*}{\multicolumn{3}{|c|}{ Recent alluvium }} & \multirow{4}{*}{$\begin{array}{l}\text { Post- } \\
\text { Modesto }\end{array}$} & & IV \\
\hline & Historic & & & & & & & & & III \\
\hline & Prenistoric & & & & & & & & & II \\
\hline & Early Holocene & & & & & & & & & I \\
\hline \multirow{8}{*}{\multicolumn{2}{|c|}{ Pleistocene }} & \multirow{8}{*}{$\begin{array}{l}\text { Victor } \\
\text { Formation }\end{array}$} & \multirow{2}{*}{$\begin{array}{l}\text { Modesto } \\
\text { Formation }\end{array}$} & \multirow{2}{*}{$\begin{array}{l}\text { Modesto } \\
\text { Formation }\end{array}$} & \multirow{2}{*}{$\begin{array}{c}\text { Modesto } \\
\text { For- } \\
\text { mation }\end{array}$} & \multirow{2}{*}{\multicolumn{2}{|c|}{$\begin{array}{c}\text { Younger portion } \\
\text { Older portion }\end{array}$}} & \multirow{2}{*}{$\begin{array}{l}\text { Modesto } \\
\text { Formation }\end{array}$} & \multicolumn{2}{|r|}{ Upper member } \\
\hline & & & & & & & & & \multicolumn{2}{|r|}{ Lower member } \\
\hline & & & \multirow{3}{*}{$\begin{array}{l}\text { Riverbank } \\
\text { Formation }\end{array}$} & \multirow{3}{*}{$\begin{array}{l}\text { Riverbank } \\
\text { Formation }\end{array}$} & \multirow{3}{*}{\multicolumn{3}{|c|}{ Riverbank Formation }} & \multirow{3}{*}{$\begin{array}{l}\text { Riverbank } \\
\text { Formation }\end{array}$} & \multicolumn{2}{|r|}{ Upper unit } \\
\hline & & & & & & & & & \multicolumn{2}{|r|}{ Middle unit } \\
\hline & & & & & & & & & \multicolumn{2}{|r|}{ Lower unit } \\
\hline & & & \multirow{3}{*}{$\begin{array}{l}\text { Turlock } \\
\text { Lake } \\
\text { Formation }\end{array}$} & \multirow{3}{*}{$\begin{array}{l}\text { Turlock } \\
\text { Lake } \\
\text { Formation }\end{array}$} & \multirow{3}{*}{$\begin{array}{c}\text { Turlock } \\
\text { Lake } \\
\text { For- } \\
\text { mation }\end{array}$} & \multirow{2}{*}{$\begin{array}{l}\text { Young- } \\
\text { er por- } \\
\text { tion }\end{array}$} & Pumice near Friant & \multirow{3}{*}{$\begin{array}{c}\text { Turfock } \\
\text { Lake } \\
\text { Formation }\end{array}$} & \multirow{2}{*}{$\begin{array}{c}\text { Upper } \\
\text { unit }\end{array}$} & Friant Pumice Member \\
\hline & & & & & & & Corcoran Clay Member & & & Corcoran Clay Member \\
\hline & & & & & & \multicolumn{2}{|r|}{ Older portion } & & & Lower unit \\
\hline & $\begin{array}{l}\text { eistocene } \\
\text { Pliocene }\end{array}$ & $\begin{array}{c}\text { Arroyo Seco } \\
\text { Gravel }\end{array}$ & & $\begin{array}{c}\text { North Merced } \\
\text { Gravel }\end{array}$ & & & & $\begin{array}{l}\text { North } \\
\text { Merced } \\
\text { Gravel }\end{array}$ & & \\
\hline & & & & China Hat & & & & & Uppers & China Hat Gravel Member \\
\hline Late & e Pliocene & Formation & & & & & & Laguina & & \\
\hline & & & & & & & & & & Lower unit \\
\hline
\end{tabular}

FiguRE 2.-Relation of proposed stratigraphic nomenclature to that previously used in northeastern San Joaquin Valley. 
TABLE 2-Comparison of some age-diagnostic relict soils

[Soils compared are formed on uneroded or very alightly eroded arlosic alluvial sand in the Merced River area. clay rich, and generally better developed. All data and statements in this table represent typical values or

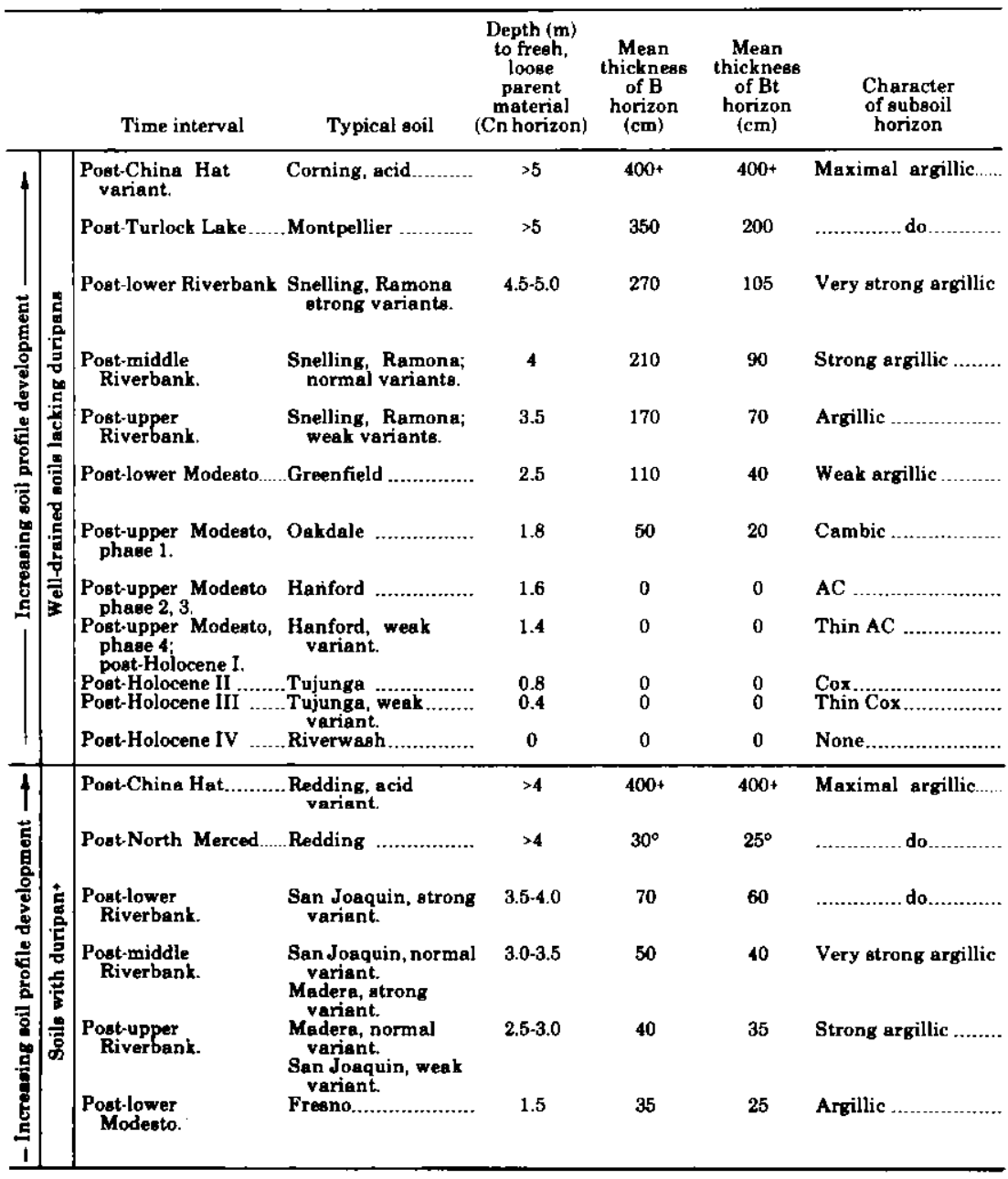

"Filme and coatinge on clagts and ped eurfaces may show redder hues and brighter chromas. + Soilu with duripans (cemented horizons) appear to have developed under impeded drainage during at least part of their history.

\section{ACKNOWLEDGMENTS}

We gratefully acknowledge the assistance of many geologists and soil scientists in providing valuable information and constructive criticism during the preparation of this report. In particular we appreciate the assistance of R. J. Arkley, J. A. Bartow, E. L. Begg, Jennifer Harden, E. J. Helley, N. K. Huber, G. L. Huntington, R. J. Janda, Ron Ollenberger, William Page, Steve Soenke, and Clyde Wahrhaftig. 
in the northeastern San Joaquin Valley

Soils formed on deposits in drainages having more metavolcanic or volcanic source areas tend to be redder, more approximate averages. Undergcoring indicates most typical value]

\begin{tabular}{|c|c|c|c|c|}
\hline $\begin{array}{l}\text { Most } \\
\text { representative } \\
\text { continuous } \\
\text { moist color } \\
\text { of subsoil } \\
\text { (Mungell)* }\end{array}$ & $\begin{array}{l}\text { Mean pH } \\
\text { of all } \\
\text { horizons }\end{array}$ & $\begin{array}{l}\text { Maximum } \\
\text { bulk density } \\
\text { of horizon } \\
\text { in } \mathrm{B} \text { position }\end{array}$ & $\begin{array}{l}\text { Clay and iron } \\
\text { oxides in } \\
\text { best developed } \\
\text { eubsoil horizon }\end{array}$ & $\begin{array}{l}\text { Character } \\
\text { and thickness } \\
\text { of duripan }\end{array}$ \\
\hline $10 \mathrm{R} 3 / 6 \cdot 8 \mathrm{~m}$ & $4.5 \pm 0.5$ & 2.1 & $\begin{array}{l}\text { Pores filled; thick, continuous coatings } \\
\text { on large clasts and over ped surfaces } \\
\text { to } 300 \mathrm{~cm} \text { or more. }\end{array}$ & None. \\
\hline $2.5 Y R \quad 4 / 6-8 m$ & $5.6 \pm 0.6$ & 2.1 & $\begin{array}{l}\text { Pores filled; thick, continuous, } \\
\text { costings on large clasts; moderately } \\
\text { thick, subcontinuous over ped faces. }\end{array}$ & None. \\
\hline $5 Y R-2.5 Y R 4 / 6 m$ & $5.9 \pm 0.6$ & 2.0 & $\begin{array}{l}\text { Pored filled; moderately thick coatings } \\
\text { on large clasts; thin to moderate, } \\
\text { discontinuous coatings over ped } \\
\text { faces. }\end{array}$ & None. \\
\hline $7.5-5 Y R 4 / 4.6 \mathrm{~m}$ & $6.0 \pm 0.6$ & 2.0 & $\begin{array}{l}\text { Pores filled, moder ate to thin and } \\
\text { discontinuous coatings on large clasta; } \\
\text { a few thin costings on major peds. }\end{array}$ & None. \\
\hline $7.5 \mathrm{YR} 4 / 4 \mathrm{~m}$ & $6.3 \pm 0.6$ & 2.0 & $\begin{array}{l}\text { Most pores filled; some thin, } \\
\text { discontinuous coatings on large } \\
\text { clasts. }\end{array}$ & None. \\
\hline $\begin{array}{l}\text { 10YR-7.5YR } \\
4 / 3-4 \mathrm{~m}\end{array}$ & $6.6 \pm 0.7$ & 1.9 & $\begin{array}{l}\text { Pores partially filled; oome very thin, } \\
\text { extremely discontinuous coatings on } \\
\text { large claate. }\end{array}$ & None. \\
\hline $\begin{array}{l}10 Y R-7.5 Y R \\
4 / 3-4 m\end{array}$ & $6.8 \pm 0.8$ & 1.8 & $\begin{array}{l}\text { Thin filme along root holes, some } \\
\text { partial filling of pores; usually } \\
\text { no coatings on large clasts. }\end{array}$ & None. \\
\hline $10 \mathrm{YR}_{4} / 3 \mathrm{~m}$ & $6.9+0.8$ & 1.7 & $\begin{array}{l}\text { Thin films along root holes and thin } \\
\text { coatings on grains; no pore fillinge. }\end{array}$ & None. \\
\hline $10 \mathrm{YR} 4 / 3 \mathrm{~m}$ & $7.0 \pm 0.8$ & 1.6 & $\begin{array}{l}\text { Some very thin, extremely } \\
\text { discontinuous coatings on grains } \\
\text { and along root holes. }\end{array}$ & None. \\
\hline $\begin{array}{l}10 \mathrm{YR} 4 / 3 \mathrm{~m} \\
10 \mathrm{YR} 4-5 / 3 \mathrm{~m}\end{array}$ & $\begin{array}{r}7.6+0.9 \\
7.8 \pm 1.0\end{array}$ & $\begin{array}{l}1.4 \\
1.3\end{array}$ & $\begin{array}{l}\text { None evident. } \\
\text { None evident. }\end{array}$ & $\begin{array}{l}\text { None. } \\
\text { None. }\end{array}$ \\
\hline $10 Y R 56 / 2 \mathrm{~m}$ & $7.9 \pm 1.0$ & 1.3 & None evident. & None. \\
\hline $10 \mathrm{R} 3 / 6-8 \mathrm{~m}$ & $4.5 \pm 0.5$ & 2.1 & $\begin{array}{l}\text { Pores filled; thick, continuous coatings } \\
\text { on large clasta and over ped surfaces } \\
\text { to } 300 \mathrm{~cm} \text { or more. }\end{array}$ & $\begin{array}{l}\text { Silica-iron } \\
\text { marimal;up } \\
\text { to } 100 \mathrm{~cm} .\end{array}$ \\
\hline $\begin{array}{l}2.5 Y R \cdot 10 R \\
4 / 6-8 \mathrm{~m}\end{array}$ & $5.0 \pm 0.5$ & 2.1 & $\begin{array}{l}\text { Pores filjed; thick, continuous contings } \\
\text { on large clasts and over ped surfaces } \\
\text { to } 300 \mathrm{~cm} \text { or more. }\end{array}$ & $\begin{array}{l}\text { Silica-iron } \\
\text { maximal;up } \\
\text { to } 100 \mathrm{~cm} .\end{array}$ \\
\hline $2.5 Y R 4 / 6 \mathrm{~m}$ & $5.9 \pm 0.6$ & 2.0 & $\begin{array}{l}\text { Pores filled; thick, continuous coatings } \\
\text { on large clasts and over ped surfaces } \\
\text { to } 300 \mathrm{~cm} \text { or more. }\end{array}$ & $\begin{array}{l}\text { Silica-iron } \\
\text { maximal;up } \\
\text { to } 100 \mathrm{~cm} .\end{array}$ \\
\hline $\begin{array}{l}5 Y R-2.5 Y R \\
4 / 4-6 m\end{array}$ & $6.0 \pm 0.6$ & 2.0 & $\begin{array}{l}\text { Pores filled; moderately thick coatings } \\
\text { on large clasts and over ped faces. }\end{array}$ & $\begin{array}{l}\text { Silicairon, } \\
\text { maximal;up } \\
\text { to } 50 \mathrm{~cm} .\end{array}$ \\
\hline $\begin{array}{l}7.5 Y R-5 Y R \\
4 / 4 \mathrm{~m}\end{array}$ & $6.2 \pm 0.6$ & 2.0 & $\begin{array}{l}\text { Pores mastly filled; thin, discontin- } \\
\text { uous films on large clasts. }\end{array}$ & $\begin{array}{l}\text { Silica-iron, with } \\
\mathrm{CaCO}_{3} \text { eeams; } \\
\text { atrong; up to } \\
40 \mathrm{~cm} \text {. }\end{array}$ \\
\hline $10 \mathrm{YR} 4 / 4 \mathrm{~m}$ & $8.5 \pm 0.7$ & 1.9 & $\begin{array}{l}\text { Pores partially filled; thin coatings on } \\
\text { grains. }\end{array}$ & $\begin{array}{l}\mathrm{CaCO}_{3} \text {-gilica; } \\
\text { moderate; up } \\
\text { to } 35 \mathrm{~cm} \text {. }\end{array}$ \\
\hline
\end{tabular}

\$Parent material containg locally derived detritus, in part from andeatic aource.

Affected by proximity of underlying unit, which controle poeition of hardpan.

\section{DIAGNOSTIC CRITERIA}

The Post Laguna stratigraphic units discussed in this report differ from conventional units in several respects. They are mappable lithostratigraphic units with clearly defined tops and bottoms but are defined only to a limited degree by lithology and superposition. Type sections are useful to some extent, but lateral and vertical lithologic variations within a single unit are frequently more pronounced than differences between units. The principal 
characteristics that serve to differentiate Quaternary deposits in the northeastern San Joaquin Valley are (1) truncation or incision of one alluvial fill by another, (2) relative elevation in a sequence of geomorphic surfaces, (3) degree of erosional dissection or preservation of depositional surfaces, (4) superposition and presence of buried soils, and (5) contrasting soil development on uneroded and lithologically comparable parent material under similar conditions of drainage and climate. Weathering and topographic features therefore become major distinguishing properties and are discussed below in some detail for each of the proposed stratigraphic units.

The post-Mehrten alluvial deposits (excluding the North Merced Gravel) are similar in that they are predominantly arkosic, ${ }^{1}$ except where derived from local drainages that head in metamorphic or Tertiary volcanic and sedimentary rocks of the foothills. In interfluve areas relatively high on the major alluvial fans, almost all units, including those of the Laguna Formation, display an upward, frequently abrupt coarsening from well-stratified fine sand, silt, or clay near the base to coarse pebbly sand or gravel near the top. Finer grained, better stratified deposits are more common in fan interfluves and toward the west, on the alluvial fan toes. Local lacustrine deposits were laid down where rapid mainstream aggradation blocked preexisting tributary drainages. Eolian sand deposits occur where sandy alluvium of terraces or fans was reworked into low dunes.

Deposits younger than the Turlock Lake Formation occur as a series of nested terraces incised in older deposits near the Sierra Nevada foothills and opening westward onto alluvial fans. Each alluvial fan commonly spills out west of and over the next oldest fan, such that the youngest fans are found close to the lower San Joaquin River, ${ }^{2}$ whereas the oldest fans head near the foothills to the east (pl. 1). Geomorphic evidence of relative age is thus most useful near the mountains, where cut-and-fill relations are often seen, but westward toward the basin the depositional surfaces converge (compare gradients in table 1) so that soils and superposition of deposits separated by buried soils become the primary distinguishing criteria. These buried soils, where they occur within soil auger depth (about $1.7 \mathrm{~m}$ ), are often recognized as separate soil

\footnotetext{
'The term arkosic, as used in this report, refers specifically to a mineralogy dominated by quartz, sodium and potassium feldspar, and biotite with subordinate amounts of hornblende, magnetite, and other mañc or opaque minerals. This mineralogy contrasts with that of sediment derived from the andesitic Mehrten Formation along the foothills, whichs lacks biotite and contains much more calcic plagioclase, amphibole, and pyroxene and less sodium and potassium feldapar and quartz.
}

\footnotetext{
2The term "lower San Joaquin River" refers to the part north of Mendota that flows north toward the Sacramento-San Joaquin Delta. Similarly, the term "upper San Joaquin River" refers to the weat-flowing part east of Mendota between Freano and Madera.
} 
map units-for example, Foster over Temple soils, Grangeville over alkali hardpan, Grangeville over Traver soils, and Ramona, hard substratum phase (Ulrich and Stromberg, 1962; Huntington, 1971). Unconformities and buried soils have not been traced in the subsurface across the axis of the San Joaquin Valley (Janda and Croft, 1967; Croft, 1972), so basin deposition may well have been nearly continuous, although fluctuating in rate, throughout late Cenozoic time.

Most of the post-Mehrten units, subunits, and members recognized in this report represent separate alluvial fills as opposed to strath surfaces cut in preexisting alluvium. Criteria for recognition of fills include: (1) more than $2 \mathrm{~m}$ of nongravelly sediment superposed over older units, (2) local lithologic contrasts, either in grain size or provenance, between deposits, (3) opening of terraces westward onto alluvial fans, (4) closed depressions at the mouths of sidestream gullies along the back edges of terraces or the margins of alluvial fans, caused by blockage of tributaries by rapid mainstream aggradation. Using these criteria, the following units clearly represent separate alluvial fills: both units of the Laguna, both units of the Turlock Lake, all three units of the Riverbank, the lower member and phases 1 and 2 of the upper member of the Modesto, and at least in some areas, all post-Modesto deposits. The North Merced Gravel is a pediment veneer over an erosional surface; no evidence to date demonstrates local alluvial filling. Present evidence is insufficient to determine whether the two phases of the lower member and the last two phases of the upper member of the Modesto represent separate alluvial fills.

\section{DESCRIPTION OF STRATIGRAPHIC UNITS}

\section{PRE-LAGUNA TERTIARY UNITS}

A series of predominantly nonmarine Tertiary clastic deposits rest on granitic and metamorphic basement along the northeastern margin of the San Joaquin Valley (pl. 1) and on Cretaceous sedimentary rocks beneath the valley floor. They dip gently southwestward (table 1) beneath the Quaternary alluvial deposits which cover most of the valley bottom. These Tertiary formations are not of primary concern to this paper and will therefore be described only cursorily except for the Laguna Formation. More detailed accounts may be found in Allen (1929), Gale, Piper, and Thomas (1939), and Gillam (1974).

The oldest of these, the Ione Formation (Eocene), consists primarily of light-brown, tan, and gray to pinkish or yellowish quartz sandstone with interbedded kaolinitic clay, usually near the base. The sandstone becomes conglomeratic and very strongly 
cemented near the top, where it locally contains marine fossils. In many places these cemented beds form resistant westward-sloping (table 1) cuestas over basement outcrops along the east margin of the San Joaquin Valley and in the westernmost foothills of the Sierra Nevada. The Ione appears to have been deposited in a fluctuating swamp and deltaic environment close to the marine shoreline (Gilliam, 1974). Lateritic soils containing crystalline iron oxides and abundant kaolinite (oxisols in the 7 th approximation classification) formed on, beneath, and perhaps within the Ione, together with plant macrofossils, indicate a tropical or subtropical climate before, during, and after Ione deposition. Ely, Grant, and McCleary (1977) have discussed some aspects of lateritic crust remnants on the buried and exhumed Ione surface in eastern Stanislaus and Merced Counties.

The Valley Springs Formation (Oligocene and Miocene), a sequence of rhyolitic sandstone, siltstone, claystone, and conglomerate that appears to have been deposited by streams flowing in post-Ione valleys having $30 \mathrm{~m}$ or more of local relief, overlies the Ione from Merced County northward. The Valley Springs Formation crops out at slightly lower elevations than the Ione, either in valleys between exposures of the Ione or to the west of them where the Ione dips valleyward beneath the surface. The Valley Springs also contains thick ledge-forming altered zones that are kaolinitic and often pisolitic and that may represent diagenetically altered paleosols formed under climatic conditions much wetter and perhaps warmer than present.

Overlying the Valley Springs and cropping out in the band west of it is the Mehrten Formation of Miocene to late Pliocene age (Dalrymple, 1963, 1964), consisting in this area of conglomerate, sandstone, siltstone, and claystone derived from andesitic source material. A general decrease in mean grain size within the Mehrten can be seen southward from the Stanislaus to the Fresno River, where Mehrten exposures cease. The Mehrten in the northeastern San Joaquin Valley was apparently laid down by southwesttrending streams carrying andesitic debris from the central and northern Sierra Nevada. Like the Ione and Valley Springs, the Mehrten also dips southwestward but at a somewhat gentler gradient than the Valley Springs. Arkley (1962a) gives an approximate slope of $18.9 \mathrm{~m} / \mathrm{km}$ for the reconstructed Mehrten depositional surface near Merced (table 1). In this area the Mehrten is much thicker than the older Tertiary units, and consequently it crops out much more extensively. The Mehrten was deposited over an extended period of time, perhaps as much as $10 / \mathrm{m}$.y. (J.A. Bartow, oral commun., 1979), and contains numerous weak to moderately 
developed paleosols in its upper part. The uppermost Mehrten also includes light-colored or reddish gravel and sand beds easily confused with those of the Laguna.

Near Friant, in Madera and Fresno Counties, Janda (1966) has recognized a sequence of tuffaceous silt, sand, and gravel deposits younger than the Ione Formation and older than the Turlock Lake Formation. These deposits, described by Janda (1966) and earlier mapped by MacDonald (1941), lie beneath the trachyandesite of Kennedy Table just east of Friant. Dalrymple $(1963,1964)$ dated as a basalt in the Jose Basin about $16 \mathrm{~km}$ east of Friant at $9.5 \pm 0.3 \mathrm{~m} . \mathrm{y}$. and correlated it with the trachandesite of Kennedy Table. K-Ar dates of approximately $10 \mathrm{~m} . \mathrm{y}$. on the basalt and of about $11 \mathrm{~m} . \mathrm{y}$. on tuff pebbles interbedded with fluvial sediment beneath the basalt indicate that the Kennedy Table deposits are older than the basalt of Jose Basin (Huber, 1980) and correlative with the older part of the Mehrten.

\section{LAGUNA FORMATION}

The Laguna Formation was named by Gale, Piper, and Thomas (1939) for arkosic alluvial deposits in the vicinity of Laguna Creek, San Joaquin County, overlying the Mehrten Formation and truncated by the Arroyo Seco Gravel, which was thought by those authors to be a pediment veneer. Although the Laguna is not continuously exposed south of the Mokelumne River, in Merced County it occupies a similar stratigraphic position above the Mehrten, is truncated by the North Merced Gravel (Arkley, 1962a), and consists of granitic alluvium ranging from gravel to fine silt. Consequently, the formation name is here geographically extended to include similar deposits in Merced and Stanislaus Counties. Thick deposits of this approximate age also occur near the mouth of the Kings River (Huber, 1977, p. 31-32). The Mehrten-Laguna contact in the Mokelumne River area has been described as transitional (Gale and others, 1939), but mapping in Merced, Stanislaus, and San Joaquin Counties indicates a regional angular unconformity between the Laguna and Mehrten (table 1). Along the north side of the Stanislaus River, Laguna successively overlies basement, Ione, Valley Springs, and Mehrten, from east to west. The presence of andesitic detritus reworked from the Mehrten in the base of the Laguna in many places and of arkosic or biotitebearing-deposits in the upper Mehrten may have led to the erroneous impression of a transitional or conformable MehrtenLaguna contact.

In the region south of its type section, the Laguna is best exposed south of the Merced River. This outcrop area extends nearly to the 
Chowchilla River as a series of isolated outcrops, in most places within or slightly west of the belt of Mehrten exposures (pl.1). The Laguna may stand either as a topographic high, where the gravelly facies in its upper part are exposed, or in sideslopes and valley bottoms, where erosion has exposed the finer grained part of the formation.

In the vicinity of the type section and in Stanislaus and Merced Counties the Laguna is characterized by beds of alluvial gravel, sand, and silt. Pebbles and cobbles of quartz and metamorphic fragments dominate the gravelly units, but the matrix of the gravel and the Laguna's finer grained sediments are invariably arkosic, in contrast to the andesitic deposits of the underlying Mehrten and the darker colored, locally derived matrix within the overlying North Merced Gravel. Biotite content of the Laguna varies geographically, depending on the source area. The Laguna normally shows a moderate to strong degree of compaction, slightly greater than the Turlock lake Formation, but sand bodies at depth are in places as fresh and unconsolidated as modern channel deposits (see reference section below, unit 1 of landfill exposure). Cementation is not common below the duripan ${ }^{3}$ of the surface soil. As Gale, Piper, and Thomas (1939) have pointed out, it is often impossible to distinguish the Laguna Formation from younger granitic alluvium by lithology. Such a distinction can in many places be made only through stratigraphic relations to the pediment gravels, weathering and soil development (see table 2), or topographic setting.

The Laguna Formation consists of at least two upwardcoarsening units, separated by a well-developed buried soil and here designated the lower and upper units (fig. 2). In both units coarse gravel beds are underlain by sand, which overlies stratified silt and fine sand beds at the base.

The Laguna is well exposed at the new Merced County landfill site, about $11 \mathrm{~km}$ north of Merced and just east of Oakdale Road. The lower and upper units appear to be lithologically similar in this area. Two exposures are described below as a composite reference section for the lower unit of the Laguna Formation in this area.

\section{Reference section A, lower unit of Laguna Formation}

Location: series of roadcuts along access road into Merced County landfill site, about $11 \mathrm{~km}$ north of Merced, just eant of Oakdale Road, NW1/NW1/4 sec. 25, T.6 S., R. 13 E., Winton and Yosemite Lake $71 /$-minute quadrangles, Merced County

Unit

Thickness

Top of roadcut, crest of hill.

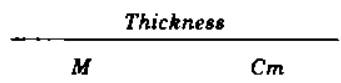

\footnotetext{
'The term "duripan" in this report refers to a pedogenic horizon formed through cementation of parent materialo by iron oxides, eilica, or calcium carbonate.
} 
Reference section A, lower unit of Laguna Formation-Continued

Unit

North Merced Gravel:

9. Gravel; weathered dark red to dark reddish brown; abundant pebbles and cobbles up to $13-15 \mathrm{~cm}$ maximum diameter in sandy matrix, extensively but not thoroughly weathered; pebbles predominantly metamorphic with some quartz; rests on Laguna Formation with pronounced erosional unconformity, seedescription under section "North Merced Gravel"

Unconformity.

Lower unit of Laguna Formation:

8. Coarse granitic sand with infrequent scattered pebble and cobble lenses; weathered reddish brown to yellowish brown; relatively massive, but original stratification extensively modified by pedogenesis; strongly cemented with iron and silica (duripan of Redding soil)

7. Coarse gravel with minor interstratified sand; weathered reddish brown to yellowish brown; pebbles up to $10 \mathrm{~cm}$ similar to those of North Merced Gravel, but matrix is arkosic; not well imbricated or stratified; strongly cemented by iron and silica in upper part becoming less cemented at depth

6. Sand with cobbly beds and lenses; weathered reddish brown to yellowish brown; moderately well indurated but not cemented

5. Coarse gravel similar to unit 3; weathered reddish brown in upper part tending toward buff or gray at depth or where soil profile has been eroded; includes prominent sandy beds; moderately well indurated

4. Coarse sand with scattered pebbles; weathered reddish brown to pale reddish brown and buff; moderately well indurated

3. Coarse sand with more pebbles than 6 above; weathered reddish brown to buff; moderately well indurated

2. Sand; weathered pale reddish brown; uniform and massive; moderately indurated

1. Sand, buff; massive irregular zone containing some pebbly lenses; moderately indurated but some zones show little evidence of weathering; base not exposed

Total thickness
90

98

90-120

90-120

2.4-3.1

Note: probable fault contact on west side, bringing uppermost Laguna (unit 8?) up against unit 1 on the east. Fault appears to offset Redding soil formed on North 
Reference section A, lower unit of Laguna Formation-Continued

Merced Gravel. The gravel beds tend to be lenticular, so thickness of units 5-9 are approximate.

No pronounced unconformities other than channels were found within reference section A of the Laguna. The coarse sand and gravel of units 2-5 above may correspond to the coarse upper material of unit 6 in the landfill exposure described below. Units 5 through 8 of the roadcut exposures apparently represent deposits removed by erosion at the location of the landfill exposure.

Reference section B, lower unit of Laguna Formation

Location: exposures in Merced County landfill site NE1/4NW1/4 sec. 25, T. 6 S., 13 E., Yosemite Lake 71/2-minute quadrangle, Merced County

Unit

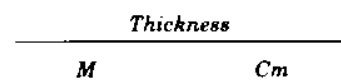

Upper surface bulldozed, original pediment veneer removed by excavation.

Lower unit of Laguna Formation:

6. Pebbly coarse sand; weathered reddish brown and reddish yellow; some less weathered lenses are grayish brown to olive brown; moderately well indurated but not cemented; largest observed pebble $6.8 \mathrm{~cm}$ diameter; prominent fluvial crossbedding and channels; minor(?) unconformity locally present at base of unit; clasts strongly weathered

5. Silty sand, predominantly light-gray to lightbuff and mottled yellow-orange to yellowbrown; fine grained; contains very few pebbles; moderately well indurated; upper $6-8 \mathrm{~cm}$ shows fairly strong platy structure, and upper $5 \mathrm{~cm}$ are more oxidized (probably pedogenic and related to the unconformity above); as a whole, the unit is not well stratified and tends to be relatively massive

4. Silt and very fine sand, light-gray; well indurated; massive

3. Very fine sand, buff to light-gray and mottled orangish; massive; well indurated; lenticular, cannot be traced laterally; typical of thin zones within the two overlying units

2. Fine sand and very fine sand, light-gray with minor yellowish-brown oxidation along thin laminae; generally massive with some fine laminae and cross-laminae; well indurated, be coming less indurated toward base.

1. Sand, light-gray and unweathered with a few yellowish-brown and reddish-brown spots along laminae, especially near upper boundary; medium grained becoming finer upward; 
Reference section B, lower unit of Laguna Formation - Continued

Unit

generally massive with internal laminae and cross-laminae; very weakly indurated to loose, somewhat more indurated near top; fresh grains of feldspar and biotite common; upper boundary is gradational and varies in level across the landfill cut (county workers report this sand at several locations in landfill subsurface boreholes

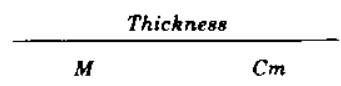

$90-120$

The Laguna includes at least one major hiatus, as shown by a buried soil in exposures along the east and north sides of the landfill site. This soil has a reddish-brown, clay-rich Bt horizon similar to that of the strongly developed Corning series, normally formed on the North Merced Gravel or the China Hat Gravel Member of the Laguna Formation; it lacks an iron-silica duripan. We have informally designated that part of the Laguna below the buried soil as the lower unit and that above it as the upper (fig. 2). Exposures of the upper unit in the landfill are too sparse to warrant a detailed description, but the deposit appears to be arkosic, fine-to coarse-grained sand and pebble gravel similar to that of the lower unit. Laguna deposits about $0.8 \mathrm{~km}$ northeast of Knights Ferry on the north side of the Stanislaus River also display a well developed red soil. R. J. Janda (oral commun., 1976) and Marchand have noted strongly developed soils in deposits akin to the Laguna south of Fresno. Ira Klein (written commun., 1975) has recognized three paleosolic zones in the eastern San Joaquin Valley subsurface beneath the Corcoran Clay Member of the Turlock Lake Formation. The oldest (lowest) of these soils may correspond to the buried soil in the Laguna Formation. Marchand has also found three very well developed buried soils beneath the Corcoran Clay Member of the Tulare Formation in U.S. Bureau of Reclamation cores from the 18-Mile Pumping Plant on the west side of the San Joaquin Valley.

The term "China Hat pediment" was applied by Hudson (1960) to remnants of an old geomorphic surface associated with gravel deposits south of the Merced River. The type section is China Hat, a conical hill in sec. 32, T.5S., R.15E., Haystack Mountain 71/2-minute quadrangle, Merced County. A thicker and better exposed section is well displayed in the Main Canal cut about $13 \mathrm{~km}$ north of Merced and $1.6 \mathrm{~km}$ east of Oakdale Road where the canal cuts through the most prominent ridge of the China Hat (pls. 1 and 2). About $18.2 \mathrm{~m}$ of 
interstratified arkosic silt, sand, and gravel is exposed in the canal cut. A number of erosional surfaces and oxidized zones can be found within this section, but these do not necessarily represent significant hiatuses. The China Hat Gravel is the stratigraphically highest unit present in this exposure and is the thickest of several gravel units in this section (elsewhere the China Hat reaches apparent thicknesses of $15 \mathrm{~m}$ or more, but here the upper gravel is only a few meters thick.) The China Hat in the canal cut rests conformably on arkosic sediment within the Laguna Formation, which is much finer grained at the contact than the overlying gravel but which itself contains the gravel units noted above. There seems to be little lithologic difference between gravel of the China Hat and the gravel beds lower in the canal section except that the China Hat is the youngest and thickest gravel. In the west side of this canal cut we found no firm evidence of a well-developed buried soil, which might indicate a major time hiatus, at the base of the China Hat Gravel. The matrix of the China Hat is arkosic, a characteristic that distinguishes the Laguna Formation from the locally derived North Merced Gravel. The North Merced Gravel and the iron-silica-cemented duripan of an eroded Redding soil, where the veneer of North Merced Gravel has been stripped, truncate the Laguna and its China Hat Gravel Member along the north and south sides of the canal cut.

We conclude from the evidence presented above that the China Hat Gravel Member is not a pediment, but rather a remnant of a late Laguna gravelly fan deposit near its apex, now prominently exposed through topographic inversion. Consequently, we here designate the China Hat as a local, uppermost member of the upper unit of the Laguna Formation rather than as a separate formation. We retain the term "China Hat," even though the deposit is not laterally continuous from one drainage to the next, because it has such topographic prominence and can be readily mapped.

The thickness of the Laguna Formation in Stanislaus and Merced Counties is uncertain because its basal contact with the Mehrten is exposed in few places and subsurface records have not been studied. The Laguna is much thinner here than in the Mokelumne River area, where Gale, Piper, and Thomas (1939) estimated up to $122 \mathrm{~m}$ of section. A probable thickness of about $15-70 \mathrm{~m}$ is reasonable for northeastern Merced County. The formation thins rapidly toward the south and does not crop out between the Chowchilla River and the San Joaquin River.

Deposits that may be in part correlative with the Laguna Formation crop out along the margins of the Sacramento and San Joaquin Valleys. Unnamed sandy arkosic deposits similar to the 
Laguna occur near the mouths of the Kings and Kaweah Rivers and of Poso Creek. Some coarse Laguna-like gravel and sand deposits occur in the upper part of the Kern River Formation of Anderson (1911) east and north of Bakersfield (Bartow and Doukas, 1976). The older silty varicolored deposits of the lower part of the Kern River Formation, however, were deposited by meandering streams, in contrast with the overloaded, braided fluvial environment suggested by much of the Laguna. The lower Kern River interfingers westward with the marine Etchegoin and San Joaquin Formations (Foss, 1972; Dibblee, 1973) of early and late Pliocene age. The Laguna is probably correlative with gravelly deposits south of Oroville, and with the older part of the Tulare Formation along the west side of the San Joaquin Valley.

Several soils have formed on the Laguna during and since its deposition. Erosion has in many places stripped away parts of the post-Laguna soils, and hence they are often not entirely agediagnostic. Acid variants of the Redding (iron-silica duripan) and Corning (no duripan) soils (table 2) have formed on the China Hat Gravel Member. A Corning soil, acid variant, formed at a relatively uneroded site on the China Hat, exposed in a 4-m soil pit excavated by Woodward Clyde Consultants and made available to us by William Page, is described below as a representative post-China Hat soil (slightly eroded).

Corning Soil series, acid variant, formed on China Hat Gravel Member

[Soil description by Jennifer W. Harden, 12/1/76 in backhoe pit in NE $1 / 4 W^{1 / 4}$ sec. 2 T. 6 S., R. 14 E., Yosemite Lake 71/2-minute quadrangle, Merced County]

0-12 cm A1 Gravelly silt loam, reddish-yellow (7.5YR 6/6d) and yellowish-brown $(10 Y R 5 / 4 \mathrm{~m})$ to dark-brown $(7.5 Y R$ $4 / 4 \mathrm{~m}$ ); weak, fine angular to subangular blocky structure, slightly hard (dry), slightly sticky, slightly plastic (wet); common medium and coarse pores; plentiful fine and medium roots; gravels are siliceous; medium acid (6.0); boundary is gradual and wavy.

$12.53 \mathrm{~cm} \quad$ A+B Gravelly silty clay loam, reddish-yellow (7.5YR $6 / 6 \mathrm{~d}$ and dark-brown $(7.5 Y R 4 / 4 \mathrm{~m})$; structure and consistence and reaction as above in $\mathrm{Al}$; common medium and coarse pores; plentiful fine and medium roots; common, thin pore fillings; clay films are common, thin bridging grains; gravels are siliceous; medium acid (6.0); boundary is abrupt and wavy.

$53-140 \mathrm{~cm} \quad$ IIB21t(b?)

Extremely cobbly clay loam, yellowish-red (5YR 5/6 d) and dark-red $(2.5 Y R \quad 3 / 6 \mathrm{~m})$; structure appears moderately strong, medium subangular blocky (cobbles interfere); extremely hard (dry), very sticky, very plastic (wet); common, medium pores; few, medium roots to $88 \mathrm{~cm}$; cobbles are more cohesive at top of horizon; cobble and gravel size clasts; 
Corning Soil series, acid variant, formed on China Hat Gravel Member-Continued

$53-140 \mathrm{~cm} \quad$ IIB21t(b) Extremely cobbly clay loam-Continued

manganese oxide coatings very common on clasts from $53-88 \mathrm{~cm}$; strongly acid (5.5); boundary gradual, wavy.

140-234 cm IIB22t(b?) Very cobbly clay, red $(2.5 Y R 4 / 8 \mathrm{~d})$ and $\operatorname{red}(10 R 4 / 7 \mathrm{~m})$; structure similar to IIB31t(b?); extremely hard (dry), very sticky, very plastic (wet); common medium pores; clay films are continuous, extremely thick everywhere, with colors of $10 R 3 / 6 \mathrm{~m}, 2.5 Y R 4 / 8 \mathrm{~m}$; all nonsiliceous cobbles fall apart ("ghost"); no manganese oxides; extremely acid (4.0-4.5); boundary is gradual and irregular.

234-310 cm IIB31t(b?) Very cobbly, coarse sandy clay loam, red $(2.5 Y R 4 / 8 \mathrm{~d})$ and dark-red (10R 4/8 m); weak, medium subangular blocky structure; very sticky, very plastic (wet); few, medium pores; common, moderately thick clay films bridging grains, lining pores, and coating clasts; cobbles are disintegrated; extremely acid (4.0); boundary is gradual and irregular.

$310+\mathrm{cm} \quad$ IIB32t(b?) Very cobbly, coarse sandy clay loam, dark-red (2.5YR $3 / 6 \mathrm{~d})$ and dark-red $(10 \mathrm{R} 3 / 6 \mathrm{~m})$; same as above but clay skins are few, moderately thick over grains and cobbles; gravel- and cobble-size clasts.

A discontinuous duripan (Bsim horizon) occurs about $1 \mathrm{~m}$ below the surface and is up to $0.7 \mathrm{~m}$ thick. Continuous red (10R $4 / 6-8 \mathrm{~m})$ clay films extend to $4 \mathrm{~m}$ depth, far below the duripan, indicating that the pan on the China Hat Gravel Member is a younger pedogenic feature superimposed on a very old soil. The presence of a thick maximal argillic horizon in the Laguna Formation beneath the North Merced Gravel and associated Redding duripan indicates that much of the weathering that produced the soils on the Laguna Formation and China Hat Gravel Member occurred before North Merced time. The depth of translocated clay coatings in the postChina Hat soil suggests deeper penetration of water than could occur under present climatic conditions. The Hopeton and less frequently the Montpellier soil is mapped in sandy or silty Laguna on sideslopes where the overlying China Hat Gravel Member has been removed. Some of these soil profiles, although eroded, have strong red argillic $B$ horizons extending more than $180 \mathrm{~cm}$ beneath the present land surface; oxidation may extend to more than $4.5 \mathrm{~m}$. In a few localities, the Hopeton soils have been removed by 
erosions, and soil series typical of the Turlock Lake Formation (Whitney, Rocklin) have been mapped on the finer grained and stratigraphically lower parts of the Laguna Formation. The buried soil exposed at one location within the Merced County landfill (p. 15) represents at least one long time interval of weathering and landscape stability during deposition of the Laguna.

The China Hat surface is characterized by very pronounced hogwallow or mima mound microrelief (up to $2 \mathrm{~m}$ or more of relief), which in many areas extends down dissected slopes as steep as 10 percent. Evidence of substantial burrowing and rodent disturbance in soil pits in the China Hat Gravel member (see soil description, p. 17 , upper $53 \mathrm{~cm}$ ) supports the rodent burrow origin of the mounds as originally suggested by Arkley and Brown (1954).

The age of the Laguna Formation is Pliocene, probably between 3 and $4 \mathrm{~m}$.y. We draw this conclusion from the following considerations: (1) The Laguna unconformably overlies the Mehrten Formation, whose upper part is younger than the 8.8-9.0 m.y. Tuolumne Table Mountain Latite of Dalrymple (1963) and which at Turlock Lake State Park contains a vertebrate fauna of latest Hemphillian age, possibly transitional into Blancan (Hugh Wagner, 1976, and oral commun., 1980), (2) the Laguna is truncated by the North Merced pediment, believed to be latest Pliocene or early Pleistocene in age (see below), (3) gravel deposits north of the Kings River, that we correlate with the Laguna contain clasts of basalt which give a K-Ar age of $3.76 \pm 0.08$ m.y. (N. K. Huber, 1980 , oral commun.), (4) an unnamed tuff mapped south of Oroville in the Sacramento Valley (Creely, 1965) lies within gravel deposits we tentatively correlate with the Laguna and is correlative on the basis of glass chemistry (A. M. Sarna-Wojcicki, 1980, oral commun.) with the Bear Creek Falls tuff (Nomlaki Tuff) dated at $3.3 \pm 0.4$ m.y. (Evernden and others, 1964; Sarna-Wojcicki, Bowman, and Russell, 1979), and (5) preliminary paleomagnetic studies by K. L. Verosub (oral commun., 1980) indicate that the lower unit of the Laguna in the Merced County landfill is magnetically reversed whereas the overlying upper unit in the landfill and in nearby exposures is normally magnetized (we tentatively correlate this boundary with the GilbertGauss reversal, presently placed at about 3.4 m.y. (Mankinen and Dalrymple, 1979).

\section{NORTH MERCED GRAVEL}

The North Merced Gravel, named by Arkley (1962a, p. 29) 
represents a thin veneer of gravel over an erosional surface of regional extent in the northeastern San Joaquin Valley. The geomorphic surface called the North Merced pediment by Arkley meets criteria for a pediment in that (1) it is an erosional surface of low relief cut across a variety of rock types and having regional extent, (2) it is covered by a thin deposit of coarse locally derived gravel, and (3) it appears to have developed in a semiarid climate similar to that of the present. ${ }^{4}$

Remnants of the North Merced pediment are best preserved in the Snelling, Merced Falls, Yosemite Lake, and Haystack Mountain 71/2-minute quadrangles of northeastern Merced County (plates 1 and 2; Marchand, 1976a, sheets 6 and 7) but may be traced at least as far south as the San Joaquin River. The gravel veneer is correlative with part of the Arroyo Seco Gravel of Gale, Piper, and Thomas (1939) to the north (Arkley, 1962a), but the Arroyo Seco as mapped by Gale, Piper, and Thomas includes substantial areas of Laguna. We do not use the term Arroyo Seco here and suggest that it be abandoned.

The North Merced Gravel truncates, in general westward progression, Mesozoic granitic and metamorphic rocks, and the Ione, Valley Springs, Mehrten, and Laguna Formations. The lower unit of the Turlock Lake Formation and younger Quaternary deposits were laid down on topography deeply incised into the North Merced surface.

The pediment is associated with a discontinuous, gently sloping topographic surface between the Sierra Nevada foothills and the Quaternary alluvial fans. A reconstructed topographic surface on the highest smooth pediment remnants slopes steeply in places, especially near bedrock outcrops, but does not appear to have been significantly tilted to the west as the depositional surfaces of the China Hat, Laguna, and older stratigraphic units have been. Instead, the North Merced pediment tends to conform to local topography and often displays local slopes in many directions, although the mean gradient in the Snelling-Merced area is about 6 $\mathrm{m} / \mathrm{km}$ toward the west-southwest (table 1). A mima mound topography less pronounced than that associated with the China Hat Gravel Member (Nikiforoff, 1941; Arkley and Brown, 1954) has developed almost everywhere on the pediment surface. The duripan of the Redding soil creates a perched water table, and the undrained depressions frequently hold water during the winter rainy season.

\footnotetext{
-The Redding and Corning soils characteristically formed on the North Merced Gravel are xeralfs (Noncalcic Brown Soile) similar to those presently forming on Quaternary deposits of the region.
} 
Detailed mapping in the Merced area has shown that what has been called the North Merced pediment is actually two or more erosional surfaces of significantly different ages. The fully developed Redding soil, with a $2.5 Y R-10 R$ 4/6-8m Bt horizon containing 50-60 percent clay above a maximally developed silicairon cemented hardpan (table 2 ) is found only on topographic flats or benches. Soils on gravel-veneered sideslopes having gradients of 5-10 percent do not have the intense development of the Redding and are more akin to the weak or normal variant of the San Joaquin or Yokohl series (table 2), although they may be mapped as Redding, Corning, Rockling, or Keyes. In many areas, especially along Hornitos and Snelling Roads in the Yosemite Lake $71 / 2$ minute quadrangle northeast of merced, these younger slopes merge into smooth surfaces lying significantly below the level of the North Merced benches (Marchand, 1976a, sheet 6). These lower surfaces in turn merge with surfaces underlain by the upper unit of the Riverbank Formation - for example, northwest of Fahrens Creek, Yosemite Lake quadrangle. The North Merced pediment therefore appears to have undergone at least one period of extensive dissection, colluviation, and regarding during late Riverbank time (see also Harden and Marchand, 1980). Slopes bearing weakly developed soils such as cobbly variants of the Pentz and Peters series, formed in part on colluvium or lag gravel overlying nongravelly Tertiary or older rocks, may represent erosional surfaces developed during Modesto time.

The North Merced Gravel is usually less than $2 \mathrm{~m}$ thick, although in a few places it reaches $4 \mathrm{~m}$. Pebbles and cobles may be $15 \mathrm{~cm}$ or more in maximum diameter and are predominantly of quartz-vein or mixed metamorphic source. Granitic pebbles and cobbles are conspicuously absent. The gravel matrix is locally derived, but intense weathering has converted most of the weatherable grains to pedogenic clay.

The most characteristic soil developed on the North Merced Gravel is the Redding series (Abruptic Durixeralf), an acid (pH $5.1 \pm 0.6$ ), red (hues $2.5 Y R$ to $10 R$, chromas 6 to 8 ), montmorillonitic soil with a maximal argillic $B$ horizon and well-developed ironsilica duripan more than $0.5 \mathrm{~m}$ thick (table 2). The hardpan has in most places formed along the unconformity underlying the pediment gravels and its vertical position within the soil profile commonly appears to be controlled by the change in parent material or the presence of a buried argillic horizon. The Corning soil series is locally mapped where the duripan is absent.

The North Merced Gravel and the Redding soil that has formed on it are difficult to describe separately because the post-pediment 
soil is strongly developed and extends through the gravel into the underlying material. The Redding soil series and its parent material are described below as exposed above the Laguna Formation along the Merced County landfill access road. Arkley (1962a) did not designate a type section, but this exposure serves that purpose.

\section{Type section, North Merced Gravel}

Location: access road to Merced County landfill site, NE $1 / 4$ NW1/4 sec. 25, T. 6 S., R. 13 E., Yosemite Lake $71 / 2$ minute quadrangle, Merced County

Redding soil series, formed on North Merced Gravel (description by Jennifer W. Harden in backhoe pit just north of road on low ridge crest):

0-5 cm Ap Gravelly loam, dark-brown (7.5YR 4/4d) and strong brown $(7.5 Y R 3 / 4 \mathrm{~m})$; friable (moist), slightly sticky, slightly plastic (wet); roots common, fine; slightly acid (6.5); boundary clear and smooth.

$5.19 \mathrm{~cm} \quad$ B11 Gravelly heavy loam, dark-brown $(7.5 Y R 4 / 4 \mathrm{~d})$ and dark-reddish-brown $(5 Y R 3 / 4 \mathrm{~m})$; firm (moist), sticky, plastic (wet); roots common, fine; thin clay films on gravels; medium acid (6.0); boundary clear and wavy.

19-36 cm G12 Gravelly heavy loam, yellowish-red (5YR $5 / 6 \mathrm{~d})$ and dark-red (2.5YR $3 / 6 \mathrm{~m})$; medium subangular blocky structure; hard (dry), sticky, plastic (wet); few, fine roots; common, fine pores; few thin clay films bridging grains and coating gravels; medium acid (6.0); boundary is clear.

$36-47 \mathrm{~cm} \quad$ B21t Cobbly clay loam, yellowish-red (5YR 5/6d) and darkred $(2.5 Y R 3 / 6 \mathrm{~m})$; medium subangular blocky structure, very hard (dry), very sticky, very plastic (wet); few, fine pores; pore fillings are common, moderately thick; moderately thick clay films are bridging grains and coating cobbles; contains cobble and gravel-size clasts; strongly acid (5.5); boundary is gradual.

$47-71 \mathrm{~cm} \quad$ B22t Cobbly heavy clay loam, dark.red $(2.5 Y R 3 / 6 \mathrm{~d})$ with $5 Y R$ 4/6 d skins, same colors moist; medium subangular blocky structure, very hard (dry), very sticky, very plastic (wet); pores are common fine to medium; many thick pore fillings; clay films are common to many, coating ped faces and cobbles; contains cobble and gravel-size clasts; medium acid (6.0) boundary is abrupt and irregular.

$71+\mathrm{cm}$ IIBsimb Cobbly sandy matrix, yellowish-red $(5 Y R 6 / 6 \mathrm{~d})$ and yellowish-red (5YR 5/8 m); extremely hard (dry); cementation is strong to indurated but is quite variable horizontally and in thickness; thick clay coating is common just on top of pan and on embedded cobbles; strongly acid (5.5).

Unweathered North Merced parent material is not present, but the original deposit was probably coarse gravel containing pebbles and cobbles up to $15 \mathrm{~cm}$ in maximum diameter in a matrix of coarse 
sand, primarily derived from andesitic and metamorphic rocks of the foothills. Large metamorphic clasts that are not quartzose display thin to moderate weathering rinds but are internally fresh and coherent. Clasts are more weathered and decomposed within the $\mathrm{B}$ horizon of the Redding soil but nowhere as much as nonquartzose clasts in the China Hat Gravel Member. Smectite contents of up to 50 percent of the less-than- $2 \mu \mathrm{m}$ fraction in the post-North Merced soil are indicative of locally derived andesitic sediment from the Mehrten Formation in the North Merced parent material. The silica-iron duripan of the Redding soil has formed here on Laguna parent material underlying the North Merced Gravel. Red clay films evident in the outcrop and oriented clay visible in thin sections well below the zone of cementation indicate that the Redding duripan formed on a pre-North Merced argillic B horizon in the Laguna Formation (intra-Laguna soil, exposed in nearby landfill cuts).

The North Merced Gravel is also well exposed in cuts along Snelling Road in the SW1/4 sec. 9, T. 6 S., R. 14 E., Yosemite Lake 71/2-minute quadrangle, Merced County, and in a streambank cut just west of Snelling Road in the extreme south-central part of sec. 4 of the same township and quadrangle. Here the coarse locally derived gravel of the North Merced, bearing the fully developed Redding soil, contrasts sharply with the fine-grained sediment of the underlying Laguna Formation (lower part of upper unit).

The age of the North Merced Gravel is somewhat uncertain but is suggested by indirect evidence. The gravel is separated from the underlying Laguna Formation by a very strongly developed soil indicative of a long time hiatus. It is older than the paleomagnetically reversed lower unit of the Turlock Lake Formation and younger than the Laguna Formation. A pediment in the eastern Sacramento Valley, which we believe to be correlative with the North Merced, overlies the 1.1-m.y.-old Deer Creek Basalt and underlies the 0.45 m.y. Maidu Ash (E. J. Helley, D. S. Harwood, Charles Meyer, Marta Woodward, A. M. Sarna-Wojcicki, oral commun., 1980). The age of the North Merced pediment, using a 1.8-m.y. age for the Tertiary-Quaternary boundary (Bandy and Wilcoxon, 1970; Berggren, 1972), is either latest Pliocene or early Pleistocene. We suggest a tentative age of about $1 \mathrm{~m} . \mathrm{y}$., which would be consistent with the antiquity implied by the very strongly developed post-pediment soil.

\section{TURLOCK LAKE FORMATION}

The Turlock Lake Formation includes arkosic alluvium and related deposits in the stratigraphic interval between the North Merced Gravel and the Riverbank Formation. Both its lower and 
upper contacts are unconformable along the eastern edge of the San Joaquin Valley, showing erosional relief of up to $30 \mathrm{~m}$ or more. The formation was first recognized by Arkley (1954) and named by Davis and Hall (1959) for arkosic silt, sand, and gravel overlying the Mehrten Formation and underlying the Riverbank Formation in eastern Stanislaus and northern Merced Counties. Although the sediments of the Turlock Lake are commonly indistinguishable from those of the older Laguna Formation or of the younger Riverbank and Modesto Formations, they bear a suite of distinctive, strongly developed haploxeralfs (Noncalcic Brown soils) and underlie a topography much more dissected than that associated with younger deposits. The formation is widely recognizable and mappable throughout the northeastern San Joaquin Valley (for example, Janda, 1965, 1966; Helley, 1967; Janda and Croft, 1967; Marchand, 1976a-f).

A buried soil as well or better developed then the relict soil formed on the upper unit of the Riverbank (see p. 40,42-43) separates the Turlock Lake Formation into two units in the northeastern San Joaquin Valley. This soil is recognizable in both surface exposures and subsurface records. We believe most of the Fair Oaks Formation of Shlemon (1967a, b), exposed along the north bluff of the American River east of Sacramento, to be correlative with the Turlock Lake Formation. At the Sunrise Boulevard Bridge the Fair Oaks contains at least three units separated by strong buried soils comparable to Ramona soils formed on the upper or middle units of the Riverbank Formation. If the thick upper and lower units of the Fair Oaks at the Sunset Boulevard Bridge section correlate with the thick upper and lower units of the Turlock Lake Formation to the south, the middle unit of the Fair Oaks appears to lack a southern counterpart, owing either to erosion or nondeposition (but also see p. 26). Such correlations, however, are extremely tenuous and await results from paleomagnetic or other dating and correlation techniques.

The term "Fair Oaks" was useful when the correlation with the Turlock Lake was uncertain. The entire area between the type Turlock Lake and the American River area has now been mapped and the Turlock Lake has been traced northward to the American River. We therefore suggest abandonment of the Fair Oaks as a stratigraphic term, expecially since the Fair Oaks as mapped by Shlemon (1967a) includes substantial areas of Laguna (Bartow and Helley, 1979).

The Turlock Lake Formation consists primarily of arkosic alluvium, mostly fine sand, silt, and in places clay at the base grading upward into coarse sand and occasional coarse pebbly 
sand or gravel. The pebbles are of granitic as well as metamorphic, volcanic, and quartz-vein rocks and are in most places not as large nor as abundant as those in the China Hat Member and North Merced Gravel. The gravel and sand beds are typically massive, lenticular, crossbedded, and difficult to trace laterally. The beds of finer grained sediment are commonly well sorted, well stratified, and internally laminated and in many places contain virtually unweathered grains of micas, feldspars, and mafic minerals. Some of these beds are of local lacustrine origin and contain plant impressions.

The Turlock Lake commonly stands topographically above the younger fans and terraces throughout the northeastern San Joaquin Valley in a broad band between the Mehrten, Laguna, and pediment outcrops to the east and the younger Riverbank and Modesto alluvial fans to the west (pl. 2). It slopes westward beneath these younger alluvial deposits at a very gentle gradient, generally about $3 \mathrm{~m} / \mathrm{km}$ (table 1). Outcrops of the Turlock Lake are widespread but discontinuous, especially near the mouths of major river canyons where incision and dissection have removed much of the older sediments. Erosion has modified the upper surface of the Turlock Lake so that little if any of the original depositional surface remains, and fan forms are not clearly evident from topography or present outcrop pattern. The closest approximation to an original fan surface in the areas mapped to date is probably those parts of the extensive outcrop areas between the Merced and Tuolumne Rivers south of Turlock Lake State Park, especially those areas where the Montpellier soil series has been mapped. The original fan apexes were probably in or close to the foothills, but their position can be only approximately determined. Present topographic relief is up to $30 \mathrm{~m}$ or more. Mima mound microrelief characterizes those areas where the Rocklin duripan soils have formed, often in association with Riverbank erosional surfaces beveled across Turlock Lake deposits.

The thickness of the Turlock Lake is variable and appears to increase toward the valley. Davis and Hall gave an estimate of 90-260 m for eastern Stanislaus County. Arkley (1962a) estimated about $315 \mathrm{~m}$ for northern Merced County, and Helley (1967, fig. 39) showed a range of about $17-70 \mathrm{~m}$ for the upper and 33-150 $\mathrm{m}$ for the lower unit ${ }^{5}$ in the Chowchilla area (table 1).

The type section of the Turlock Lake Formation is exposed in

sThe $33.150 \mathrm{~m}$ estimate represents the total thickness of arkosic sediment below the buried paleosol believed to be the intra-Turlock Lake soil and above the Mehrten Formation. The thickness may therefore include the Laguna Formation as well as the lower unit of the Turlock Lake. 
roadcuts along hillsides within Turlock Lake State Park between the lake and the Tuolumne River. Several new roadcut exposures in the surrounding area show the type section to include at least two units separated by an unconformity and well-developed buried soil, locally exhumed by post-Turlock Lake erosion. This finding is consistent with the observations of Arkley (1962a), Janda (1966), Janda and Croft (1967), and Helley (1967), who noted the presence of a major buried soil within the Turlock Lake Formation at widespread localities. Because the unconformity and buried soil were not mentioned in the original description, because new exposures in the type area now exist, and because we did not find a stratigraphic sequence which corresponded in all respects to that previously described, the type section is redescribed below. Units 4 and 5 below may be part of the lower unit but lie topographically above the projected position of the buried soil in adjacent roadcuts. They could represent a thin middle unit (see p. 24) whose soil has been removed by erosion.

Type section, Turlock Lake Formation

Location: Series of rosdcuts along Lake Road in E1/2SW1/4 gec. 31, T. 3 S., R. 13 E., proceeding eastward down the hill southwest of park headquarters. Turlock Lake State Park, Cooperstown $7 \frac{1}{2}$-minute quadrangle, Stanisiaus County (fig. 1)

Unit

Thickness

$M$ $\mathrm{Cm}$

Top of hill; topographic surface with up to $30 \mathrm{~m}$ of local relief.

Turlock Lake Formation:

Upper unit ${ }^{6}$

10. Sand; weathered brown to light brown; very poorly exposed at crest of hill

9. Silt; not well exposed; probably similar to unit 8 below

8. Silt, light-gray to white; mottled reddish yellow to brown in sandy zones and along laminae; contains interstratified very fine sand crenulated bedding with amplitude of $2-5 \mathrm{~cm}$; probably lacustrine

7. Fine sand, light.gray to light.brown abundantly mottled reddish yellow; contains scattered small pebbles up to 1.5 cm maximum diameter; poorly sorted; relatively massive with some general indication of thick bedding; upper part grades laterally in to overlying silt toward west

\footnotetext{
"Preliminary paleomagnetic studies by Kenneth L. Verosub (oral commun., 1980) of fine-grained beds within this unit indicate normal polarity throughout the exposures.
} 
Type section, Turlock Lake Formation-Continued

Unit

6. Sand, light-brown to brown; medium to coarse grained, pebbly; very friable; little weathered

Total exposed thickness of upper unit Erosional unconformity with up to $4 \mathrm{~m}$ of local relief.

Lower unit or middle unit:

5. Sand, light-brown; mottled reddish yellow; medium to fine grained; massive with faint horizontal stratification; scattered small pebbles; appears to lens out toward east and is covered by upper unit silt to west; these beds appear west of 4 and directly underlie the unconformity at that position; they appear to stratigraphically overlie 3, but exposures between the two outcrops are poor

4. Poorly exposed zone of contact between upper and lower units; medium sand with scattered cobbles, weathered reddish yellow to reddish brown; presumably part of lower unit

Lower unit:

3. Gravel; strongly weathered reddish brown to red; red clay coatings around frag. ments; contains coarse interstitial sand and interstratified sand beds; gravel contains up to 50 percent of clasts as large as $10 \mathrm{~cm}$ in maximum diameter; buried soil Bt horizon passes down through this unit into unit 2 without break; thick bedding, somewhat obscured by soil development; not well exposed; soil extends westward beneath overlying unit, but is much less well developed as a buried soil than as an exhumed soil.

2. Coarse sand with prominent gravel; weathered to uniform reddish brown to red; many decomposed pebbles but some fresh finegrained metamorphic pebbles; massive; about 25 percent gravel with clasts up to $10 \mathrm{~cm}$ in diameter (mode about $2.5 \mathrm{~cm}$ ); poorly exposed; contains frag. ments of underlying units; subcontinuous pedogenic clay films around clasts indi. cate very deep translocation of clay; soil peds are strong, coarse subangular blocky in upper part of unit becoming weaker

\begin{tabular}{ccc}
\multicolumn{2}{c}{ Thickness } & \\
\hline \multicolumn{1}{c}{$M$} & $C m$ \\
& & \\
1.4 & & \\
\hline
\end{tabular}

$9.8-10.2 \mathrm{~m}$

4.0 minimum

(base not exposed) 
Type section, Turlock Lake Formation - Continued

Unit

with depth and eventually disappearing; this stratigraphic unit appears to fall within the stripped B2t and upper C horizon of the buried post-lower unit, preupper unit soil

1. Silt and clay, gray; purplish near base; interstatified with fine sand; well stratified; relatively unweathered; not well exposed; color is inherited from underlying Mehrten Formation. Contact with Mehrten is not well exposed

Total exposed thickness of lower unit

Total exposed thickness of Turlock Lake Formation

Unconformity. Formaty.

Mehrten Formation: andeaitic sandstone and siltstone; base not exposed.

Bottom of hill (east aide).

A relatively new roadcut just west of the campground access road junction provides a much better exposure of the lower unit in the type area. This section is described below.

\section{Reference section A, Turlock Lake Formation}

Location: roadcut in NE $14 \mathrm{SW} 1 / 4$ sec. $31, \mathrm{~T}$. 3 S., R. 13 E. along new highway just west of junction with campground access road, Turlock Lake State Park, Coopergtown 71/2-minute quadrangle, Stanislaus County (fig. 1)

Unit

Flat area at top of roadcut.

Turlock Lake Formation:

Lower unit: ${ }^{7}$

7. Gravel; very strongly weathered to red and reddish brown (mapped as Corning soil series); contains interstitial coarse sand, not well exposed, especially at top; overlain unconformably by basal silt of upper member at top of hill (see type section)

6. Coarse to medium sand; weathered reddish brown; fairly massive but bedding is affected by soil formation; contains a few scattered pebbles; B horizon of exhumed buried soil extends down about 2.1-2.4 m within unit, Clox horizon to about $3.4 \mathrm{~m}$

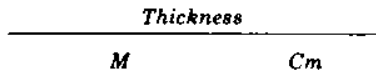

2.4 minimum 
Reference section A, Turlock Lake Formation-Continued

Unit

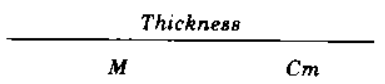

5. Medium-grained sand, yellowish-brown to light-brown; mottled strong brown along bedding planes; contains a few thin pebble lenses and beds, all pebbles small; fairly massive but some laminae are evident; well consolidated but not appreciably weathered

4. Medium sand, light-brown; finer near base; fairly massive but shows some poorly defined beds $25-30 \mathrm{~cm}$ thick

3. Silt and silty clay, gray to light-gray; very well stratified and internally laminated; very well sorted; contains some interstratified fine sand beds; internal parallel laminae especially well developed near base, in beds $3-5 \mathrm{~cm}$ thick; moderately well consolidated; probably lacustrine

2. Transition zone: silt and clay, somewhat purplish; very well stratified; generally similar to 5 above except for color.

Total thickness of lower unit Unconformity.

Mehrten Formation:

1. Andesitic sandstone with some pebbles and cobbles and well-developed large-scale crossbedding

Base of roadcut.

5.2

$\approx 19 \mathrm{~m}$

The second roadcut west of this location reveals very strongly weathered gravel with a large proportion of decomposed cobbles and pebbles at an elevation below the basal silt and clay of the lower unit. These gravel beds are overlain by a channel fill of Turlock Lake gravel. The older gravel may be part of the Laguna or it might represent a still older alluvial phase of the Turlock Lake Formation. We presently prefer the Laguna interpretation because of the extensive weathering of feldspars and pebbles. As noted above, Ira Klein (written commun., 1975) has recognized three strongly developed paleosols above the marine Tertiary and beneath the Corcoran Clay Member of the Turlock Lake. These paleosols found in U.S. Bureau of Reclamation cores from northeast of Madera to a point about $16 \mathrm{~km}$ southwest of Madera, indicated at least three periods of prolonged or intense weathering before upper Turlock Lake time.

Sandstone and claystone of the Mehrten Formation crop out down the steep bluff to the campground beneath the described 
exposure. To the east, down the access road to the campground, arkosic sediment which may be part of either the Laguna or Turlock Lake overlies the Mehrten at a much lower elevation than the Mehrten-Turlock Lake contact at the roadcut, indicating that the unconformity at the top of the Mehrten has a minimum relief of $10 \mathrm{~m}$ at this location.

The Turlock Lake Formation in its type area, Turlock Lake and vicinity, includes both the lower and upper units of the formation and provides a reasonably good representation of typical lithologic units. Neither the type section nor the reference section, however, clearly exposes the contact between the two members; therefore, an additional reference section is included below to supplement the type section.

\section{Reference section B, Turlock Lake Formation}

Location: series of roadcuts leading up Negro Hill, SW $1 / 4 \mathrm{NW}^{1 / 4} \mathrm{sec} .4, T$. 5 S., R. 14 E., about $0.8 \mathrm{~km}$ north of Snelling, Snelling 7/2-minute quadrangle, Merced County (fig. 1; pl. 2)

Unit

Summit of hill south of the road; dissected topography with up to $20 \mathrm{~m}$ of local relief.

Turlock Lake Formation:

Upper unit:

4. Not exposed; mapped as Montpellier soil series; presumably coarse sand similar to units 5 and 6 of reference section $A$, judging from nearby roadcuts at the same elevation

3. Silt and sand grading upward into medium and coarse sand; light gray becoming buff to pale red brown upward

Total thickness of upper unit

Erosional unconformity with several meters of local relief.

Lower unit:

2. Coarse silt and very fine sand; weathered red brown to buff; massive; contains scattered pebbles up to $2.5 \mathrm{~cm}$ maximum diameter; silt grades upward into very fine sand; iron-silica duripan (Rocklin soil series) developed in this material is a stripped Bsim horizon of a buried paleosol formed on the lower unit before deposition of upper member; this soil extends into the underlying gravel and forms a prominent topographic bench about halfway up the hillslopes in this area, marking the contact between the two units (pl. 2)
Thickness

$C m$
11.6

$15.8 \mathrm{~m}$ 
Reference section B, Turlock Lake Formation-Continued

Unit

$\frac{\text { Thickness }}{\mathrm{Cm}}$

1. Gravel; weathered buff to light reddish brown; fragments up to $30 \mathrm{~cm}$ in diameter; mean diameter 2.5-4 cm; contains interstitial sand; well indurated; base not exposed.

Bottom of hill.

Total exposed thickness of lower unit

Total exposed thickness of Turlock Lake

Formation

$8.8 \mathrm{~m}$

$24.6 \mathrm{~m}$

The contact between the upper and lower units of the Turlock Lake Formation is also well exposed in Southern Pacific railroad cuts about 150-300 m north of the Stanislaus River just north of Oakdale (Oakdale 71/2-minute quadrangle). The buried soil between the two units here resembles the Snelling or Ramona weak or normal variants formed on the upper and middle Riverbank.

Sediment coarsens upward in both units of the Turlock Lake. The lower unit in reference section A clearly shows this pattern. The coarse upper part of the upper unit has been stripped by erosion at the type area but occurs on hilltops immediately to the west. The coarse-over-fine stratigraphic sequence is seen in alluvium derived from all major glaciated river basins draining to the northeastern San Joaquin Valley (Janda, 1966; Janda and Croft, 1967; Arkley, 1962a). Parts of the sequence may be seen at many locations. Some of the best exposures are along Turlock and Oakdale Roads in sections 22, 23, 26, 27, and 35, T. 5 S., R. 2 E., Cressey and Winton $71 / 2$-minute quadrangles, Merced County. Thick well-bedded fine sand, silt, and clay along the base of the bluffs of Dry Creek progressively pass into sand and coarse pebbly sand at higher elevations to the west along both of these roads. Coarse uppermost alluvium is well exposed in roadcuts just east of the Hall Road-East Avenue intersection, secs. 14 and 23, T. 5 S., R. 11 E., Cressey $7 \frac{1}{2}$-minute quadrangle, Merced County. Where the well-developed Montpellier soil (Typic Haploxeralf) formed on the coarser material appears to have been only slightly eroded. Soil survey map units in much of eastern Stanislaus, Merced, Madera, and Fresno Counties serve to distinguish the uppermost coarse alluvium in both units (Montpellier or Cometa (Typic Palexeralf) soil series; occasionally Rocklin) from underlying fine sand and silt (Whitney, Rocklin, Trigo,) (pl. 2; fig. 2).

The Turlock Lake Formation is not easily distinguished from the underlying Laguna Formation, especially where the intervening 
North Merced Gravel is absent or where its relation to the deposit in question is not clear. Our experience indicates that the following criteria are useful means of differentiating the two formations, although such differentiation is not everywhere possible:

(1) Gravel beds in the upper parts of both units of the Laguna Formation tend to be thicker, coarser, and less sandy than comparable beds in both units of the Turlock Lake Formation. Only close to the foothills does the Turlock Lake become cobbly.

(2) Clasts of nonquartzose rock in the China Hat and Laguna tend to show thick weathering rinds and are often partially to thoroughly decomposed so that they can be cut through with a knife. Clasts in the Turlock Lake are normally fresher, except within the A and B horizons of the soil zone.

(3) Feldspar in the Laguna tends to be white and chalky, and biotite tends to be altered or bleached. In contrast, feldspar and biotite in the Turlock Lake Formation beneath the B horizon are frequently fresh or nearly so.

(4) The clayey, silty or fine sand beds of the Laguna tend to be slightly more compact and better consolidated than similar beds in the Turlock Lake. Laguna silt and clay beds also contain significant amounts of montmorillonitic and mixed 14A-10A clays, whereas Turlock Lake silt and clay beds are dominated by illite or kaolin group minerals.

(5) The $\mathrm{pH}$ of relict soils formed on the Laguna and China Hat is very low, usually 4.5 or less; $\mathrm{pH}$ in Turlock Lake soils goes down to about 5.2 but not below (table 2)

(6) Laguna soils, where not severely eroded, have hues of $10 R$; most Turlock Lake soils have 2.5YR hues, or, where eroded, $5 Y R$ hues.

(7) Very thick clay coatings around gravel clasts and over ped surfaces extend down more than $4 \mathrm{~m}$ in the China Hat soils but are thinner and rarely extend to more than $2 \mathrm{~m}$ depth in fully developed Turlock Lake soils.

The weathering and soil criteria must be used with particular caution, since weathering varies with depth, and virtually all postTurlock Lake and post-Laguna soils are eroded, in places deeply.

\section{LOWER UNIT}

The lower unit of the Turlock Lake Formation appears to be everywhere overlain by the upper unit. Consequently it crops out only in very small areas near major river valleys such as those of the Stanislaus, Tuolumne, Merced, and San Joaquin Rivers where erosion has removed the upper unit. The resistant nature of the buried soil, commonly stripped to an iron-silica duripan or an 
argillic B horizon, has locally allowed partial exhumation of the lower unit. We have found that the lower unit can be identified and separately mapped where well exposed. It has been recognized over broad areas in U.S. Bureau of Reclamation cores and drillers' logs (Arkley, 1962a; Janda, 1965; Helley, 1967) and may represent more than one period of aggradation (see p. 24).

The lower unit includes a sequence of gravel and coarse sand that overlies finer sand, silt, and clay of possible lacustrine origin. The clay, silt, and fine sand are well sorted nd occur in the thin welldefined horizontally laminated beds near the base of the unit. The Montpellier and Rocklin soil series have been mapped on the exhumed surface of the lower unit. The Whitney soil (Mollic Haploxeralf) is also mapped on the lower unit, especially on sideslopes where erosion has exposed the finer sediment underlying the gravel and sand near the top of the lower unit. In a few places where gravel occurs within the lower unit, usually near the top, the Corning soil series has been mapped-for example, at the type area of the Turlock Lake Formation.

The age of the lower unit must substantially exceed 600,000 years, judging from the strong development of the buried intraTurlock Lake soil (see p. 28). The fine grained deposits in reference section $A$ are paleomagnetically reversed and may include a normal interval, according to Packer and others (1977).Deposits that appear to be correlative with the lower Turlock Lake beneath the E-clay of Croft (1972) in the Wasco area core holes show reversed magnetic polarity (Davis and others, 1977). These authors also found an ash bed in the basal E-clay deposits of these cores just above the Matuyama-Brunhes reversal. They correlate this ash with the Bishop tuff, K-Ar dated at about 730,000 years (Dalrymple and others, 1965-age corrected for new I.U.G.S. decay constants). We conclude that the lower Turlock Lake predates the MatuyamaBrunhes magnetic reversal and probably predates the Bishop tuff and is therefore older than about 730,000 years. The lower unit postdates the North Merced Gravel, believed to be about 1 m.y. old (see p. 19).

\section{[UPPER I]NIT}

The upper unit of the Turlock Lake Formation underlies a rolling topography having $30 \mathrm{~m}$ or more of local relief. It caps the lower unit and older deposits along the base of the foothills, where it stands above the highest exposures of the Riverbank Formation.

The upper unit records a single major episode of alluviation. In the Merced River area it appears to include only sand and silt, except in terraces and fan remnants very close to the foothills. Gravel beds, however, occur in the upper unit in the San Joaquin, 
Fresno, Tuolumne, and Stanislaus River fans. Like the lower unit, the upper unit contains well stratified internally laminated silt and fine sand that may be lacustrine in origin. These deposits make up the middle and basal parts of the section, a relatively large proportion of the upper unit. They are probably correlative, at least in a general sense, with the Corcoran Clay Member of the Turlock Lake and Tulare Formations, a prominent aquiclude in the subsurface of the San Joaquin Valley (Frink and Kues, 1954; Janda and Croft, 1967; Croft, 1972).

The age of the upper unit appears to be about 600,000 years. This estimate is based on its normal magnetic polarity, vertebrate fauna, uranium-trend ages, and on stratigraphic relations with a $\mathrm{K}$-Ar dated pumice on and beneath the upper San Joaquin River fan (Janda, 1965, 1966; Janda and Croft, 1967). The Friant Pumice Member occurs within and near the base of the upper unit of the Turlock Lake Formation in that area and has been dated by potassium-argon at $615,000 \pm 31,000$ years old. ${ }^{8}$ In the subsurface the Friant Pumice Member is believed to rest conformably on the Corcoran Clay Member of the Tulare Formation (Janda and Croft, 1967), making the Corcoran a member of the Turlock Lake Formation in the eastern San Joaquin Valley (fig. 2) as well as a member of the Tulare Formation on the west side of the San Joaquin Valley. The strong degree of post-Turlock Lake soil development is consistent with the radiometric age of the Friant Pumice Member. Uranium-trend dating of two Montpelier soils (slightly eroded) formed on the upper unit have yielded ages of $560,000 \pm 80,000$ and $540,000 \pm 50,000$ years B.P. (J. N. Rosholt, written commun., 1980). Vertebrate fossils indicating an Irvingtonian age have been recovered from several localities within the upper unit (Janda, 1965, 1966).

Where the upper unit surface is relatively uneroded and not buried by younger deposits, the Montpellier soil series (table 2) has developed on sandy alluvium at the top of the upper unit of the Turlock Lake Formation. This soil has the following general characteristics:

Montpellier Soil Series (generalized description):

(1) An A horizon $20-50 \mathrm{~cm}$ thick; strong brown (7.5YR to $5 Y R)$ hues, moist chromas 3 to $4, \mathrm{pH} 5.7 \pm 0.5$

(2) A massive, compact B horizon 1-3 m thick; red brown to red,

\footnotetext{
"Ages on sanidine corrected for the new decay constant are $612,000 \pm 31,000(62 \mathrm{SJ}-1)$ and $618,000 \pm 31,000$ (66A()69) for two separate collections (G. B. Dalrymple, oral commun., 1980). Original dates and information are given by Janda $(1965,1966)$. Considerable uncertainty exists as to whether the Friant Pumice Member is correlative with the Reda Meadow tuffa of the upper San Joaquin drainage and with the Bishop tuff (Sarna. Wojcicki, and others, 1980).
} 
hues usually $2.5 Y R$, moist chromas 6 to $8 ; \mathrm{pH}$ similar to $\mathrm{A}$ horizon or slightly higher; strong coarse subangular blocky peds tending toward prismatic; moderately thick continuous clay films on ped faces, around clasts, and filling pore spaces, becoming thinner and less continuous with depth

(3) Somewhat consolidated sand at 2.4-3.0 m with some clay formed in place, but otherwise not strongly weathered; oxidized parent material to depths of $5 \mathrm{~m}$ or more.

These traits persist to a considerable extent even in locations where the Turlock Lake soil has been covered by early Riverbank (lower unit) alluvium. The degree of post-Turlock Lake, pre-Riverbank erosional dissection also indicates a substantial time interval between the youngest Turlock Lake and oldest Riverbank alluvial episodes. If the climate during this interval was not significantly different than that during post-Riverbank time, this period appears to have been as long as or longer than post-Riverbank time.

\section{RIVERBANK FORMATION}

Deposits now known as the Riverbank Formation were first recognized in the Merced River area by Arkley (1954) and later named in eastern Stanislaus and northern Merced Counties by Davis and Hall (1959). The term has subsequently been extended to deposits on the upper San Joaquin River fan (Janda, 1965, 1966; Janda and Croft, 1967, Huntington, 1971), the Chowchilla River fan (Helley, 1967), and in the Mokelumne and American River drainages (Shlemon, 1967a, 1967b, 1971, 1972). We have subdivided the Riverbank Formation into three informally designated units (table 3) on the basis of superposition, paleosols (table 2) and buried soils, and on geomorphic evidence (fig. 3; pl. 2). G. L. Huntington (oral commun., 1976) recognized three Riverbank units in the Fresno area, and Marchand recognizes three Riverbank units in the eastern Sacramento Valley. All these units appear to coarsen upward, like those of the Turlock Lake Formation.

The Riverbank Formation consists primarily of arkosic sediment derived mainly from the interior of the Sierra Nevada, underlying at least three sets of terraces and coalescing alluvial fans along most of the eastern San Joaquin Valley (pl. 1). The formation is also used here to include locally derived sediment from small drainage basins along the foothills. The Riverbank terraces and fans truncate or are cut into Turlock Lake alluvium or fill post-Turlock Lake gullies and ravines, and in turn they are cut and filled near the foothills by terraces of the lower member of the Modesto Formation. They slope gently to the west (table 1) beneath inter- 
distributary and fan deposits of early Modesto (lower member) age. The Riverbank as exposed in the northeastern San Joaquin Valley is primarily sand containing some scattered pebbles, gravel lenses, and some interbedded fine sand and silt. Some of the finer grained deposits are well stratified and may have been deposited in local ponds. Well-sorted sandy deposits bearing Snelling and Ramona soils may be eolian in some places. In surface exposures, however, lacustrine and eolian deposits are relatively minor. Finer-grained alluvium is not as extensively exposed as in the Turlock Lake and Modesto Formations.

The type section is located on the south bluff of the Stanislaus River in the town of Riverbank. Our stratigraphic notes at this section (where it was described) correspond fairly closely to the

TABLE 3.-Comparison of some characteristics of three units in the Riverbank Formation

\begin{tabular}{|c|c|c|c|}
\hline Unit & Lower & Middle & Upper \\
\hline Relative age ................. & Oldest & Intermediate & Youngeet. \\
\hline Areal diatribution ......... & $\begin{array}{l}\text { A few scattered rem- } \\
\text { nants on San Joaquin, } \\
\text { Merced, Tuolumne, } \\
\text { and Stanislaus Rivers. }\end{array}$ & $\begin{array}{l}\text { Widely distributed fans } \\
\text { associated with all } \\
\text { major rivers and } \\
\text { gome smaller rivers } \\
\text { (Fresno, Chowchilla). }\end{array}$ & $\begin{array}{l}\text { Confined to modern } \\
\text { drainageways, in- } \\
\text { cluding small } \\
\text { streams heading in } \\
\text { the foothills; } \\
\text { restricted occurrence on } \\
\text { major rivers, probably } \\
\text { owing to Modesto channel } \\
\text { erosion or buried. }\end{array}$ \\
\hline $\begin{array}{l}\text { Preservation of } \\
\text { depositional surface } \\
\text { (estimated). }\end{array}$ & 15 percent or lesa & $30-60$ percent & 75.95 percent \\
\hline $\begin{array}{l}\text { Local relief of } \\
\text { preaent surface. }\end{array}$ & $5-8 \mathrm{~m}$ & $2-5 \mathrm{~m}$ & $0-2 \mathrm{~m}$ \\
\hline $\begin{array}{l}\text { Fan apex position } \\
\text { of unit relative } \\
\text { to overall } \\
\text { alluvial fan. }\end{array}$ & $\begin{array}{l}\text { Indeterminate, but } \\
\text { close to fan head. }\end{array}$ & $\begin{array}{l}\text { Usually less than } 2-3 \\
\mathrm{~km} \text { from fan head. }\end{array}$ & $\begin{array}{l}\text { Usually } 10-20 \mathrm{~km} \text { from } \\
\text { fan head. }\end{array}$ \\
\hline $\begin{array}{l}\text { Characteristic } \\
\text { 'soils: } \\
\text { Arkosic, sandy } \\
\text { parent material; } \\
\text { no duripan. }\end{array}$ & $\begin{array}{l}\text { Snelling, Ramona, } \\
\text { strong variant. }\end{array}$ & $\begin{array}{l}\text { Snelling, Ramona, } \\
\text { normal variant. }\end{array}$ & $\begin{array}{l}\text { Snelling, Ramona, weak } \\
\text { variant. }\end{array}$ \\
\hline $\begin{array}{l}\text { Arkosic, sandy } \\
\text { parent material; } \\
\text { duripan. }\end{array}$ & $\begin{array}{l}\text { San Joaquin, strong } \\
\text { variant. }\end{array}$ & $\begin{array}{l}\text { San Joaquin, norma] } \\
\text { variant. } \\
\text { Madera, strong variant. }\end{array}$ & $\begin{array}{l}\text { San Joaquin, weak } \\
\text { variant. } \\
\text { Madera, normal variant. }\end{array}$ \\
\hline $\begin{array}{l}\text { Nonarkosic, sandy } \\
\text { parent material; } \\
\text { no duripan. }\end{array}$ & Not recognized.............. & 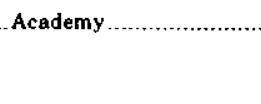 & $\begin{array}{l}\text { Not recognized; } \\
\text { Snelling, Ramona } \\
\text { mapped in areas of } \\
\text { mixed source area. }\end{array}$ \\
\hline $\begin{array}{l}\text { Nonarkosic, sandy } \\
\text { parent material; } \\
\text { duripan. }\end{array}$ & Not recognized ............... & $\begin{array}{l}\text { Yokohl, atrong } \\
\text { variant. }\end{array}$ & $\begin{array}{l}\text { Yokoh], normal } \\
\text { variant. }\end{array}$ \\
\hline
\end{tabular}




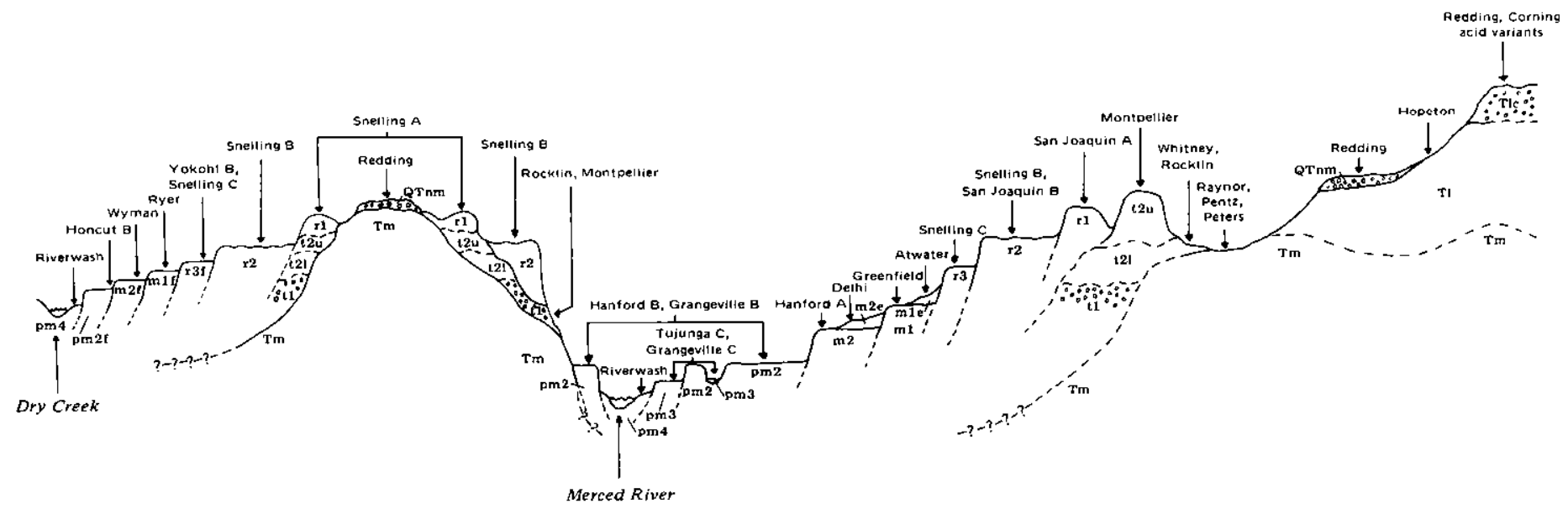

FIGURE 3.-Schematic geologic section across the Merced River near Snelling, Merced County, showing relation of soils to stratigraphic units and geomorphic surfaces. 
description of Davis and Hall (1959, p. 16-17), but the type section is redescribed below because the upper 4.3-4.9 $\mathrm{m}$ is the Modesto rather than the Riverbank Formation (see also Janda, 1966, p. 247-248), and because the Riverbank consists of two alluvial bodies separated by a conspicuous buried soil in a fresher bluff exposure just east of the type section.

\section{Type section, Riverbank Formation}

Location: exposures in south bluff of Stanislaus River in NW1/4NE $1 / 4$ sec. $26, T$. 2 S., R. 9 E., just north of intersection of Jackson and Topeka Street in Riverbank, Riverbank $7 \frac{1}{2}$-minute quadrangle, Stanislaus County (fig. 1)

$$
\text { Unit }
$$

Thickness

$\mathrm{M} \quad \mathrm{Cm}$

Top of bluff, about $10 \mathrm{~m}$ above river level; subdued dunal topography.

Modesto Formation:

Upper(?) member:

4. Disturbed material; probably sandy alluvium and eolian sand (Delhi soil series is correctly mapped elsewhere in the vicinity on upper member dune sand); lower contact not well exposed

Unconformity(?).

Lower(?) member:

3. Sand, medium to fine-grained; buff; massive; well sorted; becomes coarser tow ard base; may be either eolian or fluvial

2. Silt, light.gray; coarser lenses weathered yellowish brown; variable in thickness; well stratified, showing prominent crossstratification and internal cross-lamination; includes three or more distinct sandy and pebbly lenses as much as $10 \mathrm{~cm}$ thick, the lowest of which is predominantly gravel (2.5 $\mathrm{cm}$ maximum diameter); eastward along outcrops silty beds up to $76 \mathrm{~cm}$ thick crop out beneath the lowest gravel lens; overlies clearly visible unconformity

Unconformity.

Riverbank Formation:

Upper unit:

1. Pebbly sand, equivalent to unit 3 of Davis and Hall (1959), underlain by deposits as described by these authors except that their unit 8 (silt or clay) is locally much thicker than $30 \mathrm{~cm}(1 \mathrm{ft})$

A buried soil with incipient duripan (similar to the Madera, normal variant, but with a structural and textural $B$ horizon more like the Snelling, weak variant), developed on the Riverbank sediments, is briefly described below: 
B2b Weak argillic horizon; no evidence of translocated clay; some weak cementation by silica, iron, and calcium carbonate in lower part; surface has been eroded.

$30-46 \mathrm{~cm}$

$\mathrm{BCb}$

Transition zone showing less aggregation.

$46-114 \mathrm{~cm}$

$\mathrm{Cloxb}$

Orangish-brown zone of oxidation.

114-about $190 \mathrm{~cm}$

$\mathrm{C} 20 \times \mathrm{b}$

Yellowish-brown zone of oxidation, less well aggregated; base not clearly exposed.

over $190 \mathrm{~cm}$

Cnb

Fresh, unweathered, loose sand and silt.

An excellent exposure just east of the type section, located directly beneath a convalescent home on the bluff, shows that the Riverbank consists of at least two units and reveals a clear unconformity between the Riverbank and overlying early Modesto deposits. This section, described briefly below, also demonstrates a definite upward coarsening within the upper unit of the Riverbank and the presence of relatively coarse material at the top of the middle or lower Riverbank unit. The assignment of the lower $7.6 \mathrm{~m}$ of this section to the middle or lower unit is based on the characteristics of the buried Snelling (normal or strong variant) ${ }^{9}$ soil (table 2). This soil is much shallower (thinner Bt, B3, Cox) than any post-Turlock Lake soil seen in this region, even where the Turlock Lake has been buried by the middle unit of the Riverbank Formation, a common occurrence throughout the northeastern San Joaquin Valley, especially in eastern Madera County.

\section{Reference section A, Riverbank Formation}

Location: about $30 \mathrm{~m}$ to the east of the type section

Unit

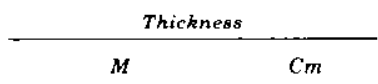

Top of bluff.

Modesto Formation:

Upper member, phase 1 (bearing Hanford soil, strong variant):

6. Fine to medium sand with scattered pebbles and occasional cobbles; upper part is disturbed in many places; weathered pale brown; relatively massive; pinches out to east under convalescent home

Unconformity.

Lower member (bearing Dinuba soil, eroded):

5. Coarse pebbly sand in channel bottom grading rapidly upward into fairly well

\footnotetext{
${ }^{9}$ The soil variants used here are our informal categories for aoil taxadjuncts that may be taxonomically outside the defined range of properties for a given soil series. They represent differences in soil profile development that are recognizable in the field and have been verified by laboratory data (Marchand and Harden, 1976; Harden and Marchand, 1977).
} 
Reference section A, Riverbank Formation-Continued

Unit

\begin{tabular}{ll}
\multicolumn{3}{c}{ Thickness } \\
\hline$M$ & $\mathrm{Cm}$
\end{tabular}

stratified very fine sand and silt; gray to pale-gray-brown becoming browner upward. Soil on silty beds, buried to west by unit 6 , is analogous to a Dinuba soil with recognizable $\mathrm{Bt}$ horizon

Total thickness of Modesto Formation

Unconformity.

Riverbank Formation:

Upper unit (bears Madera soil, eroded; to the east this unit is truncated by early Modesto channel deposit):

4. Coarse pebbly sand; weather strong brown to light reddish brown, light brown near base; in thick (up to $1 \mathrm{~m}$ ), massive beds with thin interstratified beds of silt and fine to medium sand; pebbles up to $3 \mathrm{~cm}$ maximum diameter

3. Very fine sand and sandy silt, grayish brown to gray ; fairly well stratified in beds $2-6 \mathrm{~cm}$ thick, beds coarser toward the top; transitional into overlying unit; red zone at base may reflect ground-water alteration of A horizon belonging to underlying buried soil or could be an eroded remnant of the middle unit

up to 2.5

Unconformity.

Middle or lower unit (bears Snelling, normal to strong variant soil, eroded):

2. Medium to coarse sand; weathered redbrown at top, gray to buff near base of exposure; contains a few scattered pebbles up to $2 \mathrm{~cm}$ diameter; strongly developed buried soil on this material appears to be Sneiling, normal to strong variant; B2t horizon is $\mathrm{red}(2.5 \mathrm{YR} 4 / 4 \mathrm{~m}), 12-20 \mathrm{~cm}$ thick, and shows thick continuous clay films on ped surfaces; this horizon coincides with a silty bed, so color and clay content may reflect the more weatherable finer-grained parent material. B3 horizon gives way at about $1-1.5 \mathrm{~m}$ to oxidized $\mathrm{C}$ horizon, which in turn is underlain by nearly fresh, very slightly consolidated sand. Relatively unweathered silt lying stratigraphically beneath the sand was exposed in 1977 orchard excavations near 
Reference section A, Riverbank Formation-Continued

Unit

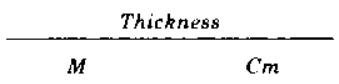

the bluff edge. To the east this unit is

truncated by the upper unit channel

1. Covered interval 3.9

Base of bluff; terrace underlain by post-Modesto II deposits

Total thickness of Riverbank Formation

up to 12.6

The Riverbank Formation comprises at least three distinct and mappable alluvial units in Stanislaus, Merced, Madera, and Fresno Counties (table 3). The type section and reference section A, as indicated above, provide good exposures of the uppermost unit and the upper part of the middle or lower unit. The Riverbank Formation at its type section, however, is truncated by the Modesto Formation, so the characteristic Riverbank topography and soils are not present. Supplementary reference sections are described below.

The age of the Riverbank Formation appears to range from about 130,000 to 450,000 years, judging from several lines of evidence. This time span would be consistent with the degree of pre-, intra-, and post-Riverbank erosional dissection and soil development and would allow for deposition of the three units as distinct alluvial episodes, separated by two substantial periods of weathering and erosion. From development of buried soils formed on the upper unit of the Riverbank below lower Modesto deposits, the Riverbank appears to predate (last interglaciation) marine isotope stage 5 . Strongly developed buried soils formed on the upper unit of the Turlock Lake Formation beneath oldest (lower unit) Riverbank deposits indicate that the Riverbank is much younger than 600,000 years. Hansen and Begg (1970) have reported open-system uraniumseries ages averaging $103,000 \pm 6,000$ on bone material from the middle unit of the Riverbank at the Teichert gravel pits east of Sacramento. These dates appear too young to us; bone has often proved a difficult medium for uranium-series methods (B. Szabo, 1976 , oral commun.). The bone dates, however, probably provide a useful minimum age for the Riverbank. The Rancholabrean vertebrate fauna associated with the Riverbank (Janda, 1965, 1966) indicates an Illinoian or Wisconsinan age.

New information provides somewhat better age control for the Riverbank Formation. Riverbank, Modesto, and Turlock Lake 
deposits associated with glaciated drainage basins such as the San Joaquin, Merced, Tuolumne, and Stanislaus are believed to represent glacial outwash from the Sierra Nevada (Arkley, 1954, 1962a; Janda, 1965, 1966; Janda and Croft, 1967; Marchand, 1977). Marchand (1977, p. 50) has therefore tentatively correlated the three Riverbank units with cold-water marine isotope stages 6 $(127,000-190,000), 8(247,000-276,000)$, and $10(336,000-356,000)$ and (or) $12(425,000-457,000)$ (Hays and others, 1976). Recently completed uranium-trend dating (Rosholt, 1978 and written commun., 1980) of soil samples from the Snelling area along the Merced River has yielded tentative ages of $140,000 \pm 45,000$ and $150,000 \pm 20,000$ B.P. for the upper unit of the Riverbank and $260,000 \pm 45,000$ B.P. for the middle unit. These ages are in good agreement with the geologic evidence summarized above. We emphasize, however, that uraniumtrend dating is at present a new and relatively untested technique.

Like the Turlock Lake Formation, the Riverbank shows a variable thickness that tends to increase toward the major river channels and basinward. Davis and Hall (1959) indicated an approximate thickness of 45-60 m in northern Merced and eastern Stanislaus Counties. Arkley (1962a) suggested a thickness of about $80 \mathrm{~m}$ along the Merced River, and Helley (1967, fig. 39) showed about $20 \mathrm{~m}$ along the Chowchilla River (table 1).

I. OWER I'NII

The lower unit of the Riverbank Formation is the least extensive of the three units in its present outcrops (table 3), although its original extent could have been as great as either of the later Riverbank fans. The lower unit is here defined to encompass all deposits older than the middle unit of the Riverbank and younger than the Turlock Lake Formation; it may include deposits from more than one aggradational cycle. It is now preserved only in a few locations on the Mokelumne, Cosumnes, Calaveras, Stanislaus, Tuolumne, Merced, and San Joaquin Rivers (pl. 1). One of the largest remnants lies immediately north of the Merced River in the Snelling and Turlock Lake 71/2-minute quadrangles, Merced County (pl. 2; fig 3). Most of the original alluvial surface here has been removed, but remnants can be seen standing $5-10 \mathrm{~m}$ above the middle Riverbank alluvial surface at an elevation of about $95 \mathrm{~m}$ $(290 \mathrm{ft})$ where the westward trend of remnants crosses Cox Ferry Road (N1/2 secs. 11 and 12, T. 5 S., R., 13 E., Turlock Lake and Snelling $7 \frac{1}{2}$ quadrangles).

The soil developed on these remnants is mapped as the Snelling series but is much more strongly developed than the typical Snelling (normal variant) formed on the middle Riverbank 
alluvium nearby. The relict soil on the lower unit, here termed the Snelling, strong variant, displays a thick reddish-brown $(2.5 Y R$ $4 / 4 \mathrm{~m}$ ) Bt horizon with distinct and semicontinuous clay films over ped surfaces (table 2). The strong variant of the Snelling could also be considered a weak variant of the Montpellier soil series. Similarly, the strong variant of the Ramona soil, a relict soil on the lower unit of the Riverbank on both sides of the San Joaquin River near Friant (pl. 1; Marchand, 1976g, sheet 7) could be considered a weak variant of the Cometa soil.

Soils formed on the lower unit differ from soils formed on the Turlock Lake Formation primarily in the thickness of the Bt, B3, and Cox horizons and depth to fresh, loose parent material (table 2). Lower Riverbank gravelly alluvium containing some locally derived detritus and bearing a Snelling, strong variant, soil overlies a buried Rocklin soil developed on somewhat finer grained arkosic upper Turlock Lake alluvium in a roadcut several kilometers to the west ( $\mathrm{SE}^{1 / 4} \mathrm{NE}^{1 / 4}$ sec. 28, T. 5 S., R. 12 E., Cressey $71 / 2$-minute quadrangle). Northeast of Cressey and south of the Merced River (W1/2SW1/4 sec. 9, T. 6 S., R. 21 E.), a buried strongly developed soil (San Joaquin, strong variant) (table 2), stripped to the duripan, occurs in river bluff exposures in arkosic alluvium about $1 \mathrm{~m}$ below a normal variant San Joaquin soil (stripped duripan and underlying Cox horizon) formed on the middle unit. Another surface occurrence of the lower unit is along Buhach Road between secs. 17 and 18, T. 6 S., R. 13 E., Winton $71 / 2$-minute quadrangle, where the lower unit of the Riverbank again overlies eroded Turlock Lake deposits.

An isolated lower unit remnant also occurs east of Oakdale on the south side of the Stanislaus River in secs. 7 and 8, T. 2 S., R. 11 E. Here it stands as an island surrounded by Modesto channel deposits, about $10 \mathrm{~m}$ higher than the middle unit terrace, which forms a low bluff south of Oakdale. Other examples include the western part of sec. 26 , T. 11 S., R. 30 E., Lanes Bridge 71/2-minute quadrangle, Madera County, where an early Riverbank surface bearing San Joaquin and Ramona soils stands 5-10 $\mathrm{m}$ above the well-exposed middle unit alluvial surface just north of the San Joaquin River (Marchand, $1976 \mathrm{~g}$, sheet 6). The scattered occurrence of the lower unit suggests that it was not as extensive as the Turlock Lake Formation or that it was deposited as a very thin unit and was subsequently eroded over large areas.

\section{MIDDI.E I'NII'}

The middle unit of the Riverbank Formation is associated with a broad alluvial surface, commonly consisting of thin $(1.4 \mathrm{~m})$ but 
westward-thickening sandy alluvium over eroded Turlock Lake Formation. It represents a single aggradational unit. The alluvial surface, unlike that of the lower unit, is extensively preserved and is associated with the Chowchilla and Fresno River basins as well as the major rivers draining the glaciated interior of the Sierra Nevada (table 3). On the fan surfaces near the foothills, the middle unit surface stands 5-10 m below remnants of the early Riverbank surface and about 5-15 $\mathrm{m}$ above the inset terraces of late Riverbank age (pl. 2; fig. 3).

The deposits of the middle unit and their characteristic Snelling (Typic Haploxeralf) (normal variant) and San Joaquin (Abruptic Durixeralf) (normal variant) soils (table 2) are described in the supplementary reference section below.

\section{Reference section B, Riverbank Formation}

Location: Exposures along both sides of Cox Ferry Rosd on N1/4 of line between secs. 1 and 2, T. 5 S., R. 13 E., about $0.4 \mathrm{~km}$ south of Keyes Road and about $5.5 \mathrm{~km}$ west of Snelling. Turlock Lake $71 / 2$ minute quandrangle, Merced County (fig. $1 ;$ pl. 2).

$$
\text { Unit }
$$

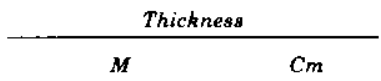

Top of roadcut; slightly dissected topography about 30

m above Merced River level.

Riverbank Formation:

Middle unit:

2. Coarse sand; weathered tan to buff; contains scattered subangular to subrounded pebbles up to $4 \mathrm{~mm}$ maximum diameter; moderately compact becoming less so toward base.

Unconformity with 1-2 m of relief; buried silica-iron duripan underlain by somewhat loose, relatively unweathered arkosic sand.

Lower unit:

1. Medium to coarse sand; weathered pale red brown to pale orange brown in upper part becoming mottled buff and gray toward base; similar to upper member at this location but contains no pebbles; lower 1-1.2 $\mathrm{m}$ are only slightly consolidated; massive with slight suggestion of coarse primary stratification; most of the observed vertical variation is pedogenic. Base not exposed

Base of roadcut.

Total thickness of exposed Riverbank Formation

$6.0 \mathrm{~m}$

The exposed section of the middle unit described above is thin and contains only sand but is one of the few places where the unit may be seen superposed over the lower unit (see p. 43) for another location). 


\section{Reference section $C$, middle unit of Riverbank Formation}

Location: north bluff of the Merced River in second gully west of Cox Ferry Road (below Silicon Valley Road) aec. 11, T. 5 S., R. 13 E., Turlock Lake 7t/2-quadrangle, Merced County (fig. 1; pl. 2)

$$
\text { Unit }
$$

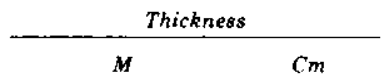

Top of bluff; smooth, relatively undissected surface about $8-9 \mathrm{~m}$ below remnants of upper unit to the north and about $20 \mathrm{~m}$ above river level.

Riverbank Formation:

Middle unit:

4. Coarse sand; weathered buff to light brown; uniform and massive; contains a few scattered pebbles and granules; any original stratification destroyed by pedogenesis

3. Coarse sand; weathered light brown to pale reddish brown; similar to unit 4 above but contains isolated pebbles and layers of cobbles up to $10 \mathrm{~cm}$ in maximum diameter; grades laterally into material like unit 1 ; crude horizontal stratification is apparent at a distance

2. Coarse sand; laminae oxidized in upper part but otherwise only slightly weathered; well stratified with fairly abundant pebbles; exidation becomes less prominent toward base; moderately indurated at top becoming very slightly indurated at base

1. Coarse sand; virtually unweathered but some cross-laminae marked by minor oxidation; unconsolidated; shows well developed festoon cross-stratification and internal cross-lamination; many pebbly lenses containing fragments up to $8 \mathrm{~cm}$ in diameter more common tow ard base; base not exposed

Bottom of bluff, top of post-Modesto II terrace.

Total thickness of exposed Riverbank Formation

The Snelling soil, normal variant, developed on the reference section sediments, is described below.

\section{Soil description, Snelling series, normal variant}

[0-386 cm described by Jennifer W. Harden in backhoe pit close to edge of bluff; soil below $386 \mathrm{~cm}$ described by Denis Marchand in natural bluff exposure]

Sandy loam, pale-brown (10YR 6/3d) and dark-brown (10YR $3 / 3 \mathrm{~m})$; moderate coarse subangular blocky structure; slightly hard (dry), nonsticky, nonplastic; 
Soil description, Snelling series, normal variant-Continued

$46-70 \mathrm{~cm}$

B1

$70-140 \mathrm{~cm}$

B21t

$140-210 \mathrm{~cm}$

B22t

$210 \cdot 386 \mathrm{~cm}$

B3t

$386-457 \mathrm{~cm} \quad \mathrm{Clox}$

$457+\mathrm{cm}$

roots are few medium; pores are abundant medium and common coarse; medium acid (6.0); boundary is clear and smooth.

Heavy sandy loam, light-yellowish-brown (10YR 6/4d) and dark-brown $(7.5 Y R 4 / 4 \mathrm{~m})$; moderate to strong. coarse to very coarse prismatic structure; very hard, slightly sticky, slightly plastic; roots are very few; pores are common to abundant medium and few coarse; clay films are common, thin bridging grains; medium acid (6.0); boundary is clear and wavy.

Light sandy clay loam, reddish-yellow (7.5YR 6/6 d) and strong-brown $(7.5 Y R 4 / 6 \mathrm{~m})$ with reddish-brown (5YR $4 / 4 \mathrm{~m}$ ) clay films; strong very coarse subangular blocky to prismatic structure; very hard (dry), slightly sticky, slightly plastic (wet); pores are few coarse and abundant medium; clay films are many, moderately thick, bridging the grains; mildly alkaline (7.5); boundary is gradual and irregular.

Sandy clay loam, reddish-yellow $(7.5 Y R$ 6/6d) and strong-brown ( $7.5 Y R 4 / 6 \mathrm{~m}$ ) with reddish-brown (5YR $4 / 4 \mathrm{~m}$ ) clay films; prismatic structure breaking to strong, very coarse subangular blocky; extremely hard (dry), sticky and plastic (wet); pores are abundant medium and few coarse; many moderately thick and few extremely thick pore fillings; clay films occur as many moderately thick grain bridges, and as common, moderately thick coats on ped faces; moderately alkaline (8.0); boundary is gradual to diffuse and irregular.

Sandy loam, brownish-yellow (10YR 6/6d) and darkbrown (7.5YR $4 / 4 \mathrm{~m}$ ); strong, very coarse subangular blocky structure, extremely hard (dry), slightly sticky Loamy sand, dark-yellowish-brown to yellowish brown (107YR 4/4m); massive to single grain; layers are platy when dry; non-sticky and nonplastic when wet; lower boundary gradational.

Sand with minor pebble lenses; unweathered; grayish brown to brown (10YR $5 / 2$ to $5 / 3 \mathrm{~m})$; single grain; nonsticky and nonplastic when wet.

\section{Reference section D, middle unit of Riverbank Formation}

Location: old railroad grade cuts in NE1/4NW1/4 sec. 36, T. 5 S., R. 13 E., just east of Highway 59 about $0.1 \mathrm{~km}$ south of Youd Road interection and about $0.8 \mathrm{~km}$ south of the Merced River, Yosemite Lake 71/2-minute quadrangle, Merced County, (fig. 1).

Top of cut; slightly irregular fan surface about $25.30 \mathrm{~m}$ above Merced River. 
Reference section D, middle unit of Riverbank Formation-Continued

Unit

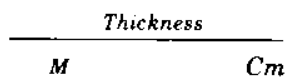

Riverbank Formation:

Middle unit:

1. Sand; weathered buff to pale reddish brown; massive; medium to coarse grained; very uniform; occasional scattered small pebbles; any primary stratification destroyed by soil development; base not exposed

Soil description: Snelling, normal variant

$0-38 \mathrm{~cm}$

$38 \cdot 51 \mathrm{~cm}$

$51-99 \mathrm{~cm}$

99-183 cm

B22t

$183.216 \mathrm{~cm}$

B23

$216-250+\mathrm{cm}$

$\operatorname{Cox}(?)$

Sandy loam, dark-brown (10YR $3 / 3 \mathrm{~m})$; medium to fine subangular blocky clods, moderately strong; very slightly to slightly sticky and nonplastic to very slightly plastic when wet; distinct lower boundary.

B1 Heavy sandy loam, dark-brown (7.5YR 4/4m); medium subangular blocky, moderately strong peds (stronger than Ap clods); slightly sticky and very slightly plastic when wet; distinct lower boundary.

B21t Sandy clay loam, dark-brown (7.5YR 4/4m); medium to coarse angular blocky, strong peds; sticky and slightly plastic when wet; gradational lower boundary.

Sandy clay loam, strong-brown $(7.5 Y R 5 / 6 \mathrm{~m})$ to yellowish-red ( $5 Y R 4 / 6 \mathrm{~m}$ ); moderately strong, coarse angular blocky, weak when wet; some clay coatings on peds but not continuous or abundant; most of clay appears to have formed in place; gradational lower boundary.

Sandy clay loam, dark-yellowish-brown (10YR 4/4m); coarse angular blocky tending toward weak prismatic peds, decreasing in strength downward; sticky and slightly plastic when wet; gradational lower boundary not well exposed.

Base of cut.

Slightly weathered sand, somewhat consolidated, not well exposed.

\section{Base of cut.}

The San Joaquin normal variant and Madera (Typic Durustalf) strong variant soils (table 2) occur where silica-iron duripan have developed on the middle unit, perhaps owing to impeded internal or external drainage during at least part of the soil development period. A typical San Joaquin normal variant profile, developed on uniform fine- to medium-grained sandy alluvium just north of the above reference section, is described below. 
Soil description, San Joaquin, normal variant ${ }^{\prime \prime}$

(same locality, a few meters to the north)

$0-20 \mathrm{~cm}$

$20-30 \mathrm{~cm}$

$30-56 \mathrm{~cm}$

B1

$56-86 \mathrm{~cm}$

B21t

$86-198 \mathrm{~cm}$

B22t

$198-218 \mathrm{~cm} \quad$ Bsim

218-254 cm C1ox

$254-315+\mathrm{cm}$

A1p

A3 toamdary

Sandy loam dark-yellowish-brown (10YR 4/4m); medium to fine subangular blocky peds, moderately strong; slightly sticky to sticky and slightly plastic to plastic when wet; gradational lower boundary

Heavy sandy loam, dark-yellowish-brown (10YR 4/4 m); medium to fine subangular blocky peds, moderately strong; slightly sticky to sticky and slightly plastic to plastic when wet; distinct lower boundary, becoming gradational in places

Sandy clay loam, light-yellowish-brown $(10 Y R 6 / 4 \mathrm{~m})$; medium to coarse subangular blocky peds, very strong; some thin pore fillings and clay films; sticky and slightly plastic to plastic when wet (more plastic than B1); distinct lower boundary

Sandy clay loam, brown $(7.5 Y R 5 / 4 \mathrm{~m})$; coarse columnar breaking to coarse to medium subangular blocky peds, very strong; abundant continuous clay films and coatings; somewhat friable when moist but generally firm, sticky, and slightly plastic to plastic when wet; abrupt lower boundary

Sandy clay loam, yellowish-red $(5 Y R 5 / 6 \mathrm{~m})$; silica-iron cemented duripan, cementation very strong; ten. dency toward platy structure at top of pan; clear lower boundary

Sandy clay loam, yellowish-red (5YR $5 / 6 \mathrm{~m})$; weakly cemented tending toward coarse subangular blocky structure downward

Sandy loam, yellowish-brown $(10 Y R 5 / 4 \mathrm{~m})$; medium to coarse subangular blocky peds, moderately strong; slightly firm when moist; very sticky and nonplastic when wet

Base of cut; fresh parent material not exposed

The duripan formed on middle-unit surfaces (San Joaquin, normal variant; Madera, strong variant) are thicker and more strongly cemented throughout compared with those of the variant formed on the upper unit. The middle-unit pan soils show redder, more clay-rich B2t horizons above the pan than the post-upper unit pan soils (table 2). Completely fresh parent material generally occurs within $3 \mathrm{~m}$ of the surface (table 2 ).

\footnotetext{
"This soil is considered a variant of the $S$ an Joaquin soil series because the upper $50 \mathrm{~cm}$ of the argillic horizon is texturally coarser than the defined limits of the soil series (G. L. Huntington, oral commun., 1976).
} 
Soils other than those discussed above also occur on the middle unit of the Riverbank Formation. In many areas on the middle unit, clay from the argillic horizons of Riverbank soils has accumulated over the duripan in local depressions. The Alamo soil series (Typic duraquoll; Humic Gley soil) is mapped in these locations and frequently displays narrow and sinuous patterns. Sidestream alluvial fans and terraces graded to the upper surface of the Riverbank's middle unit on the Merced, Tuolumne, Stanislaus, and other major rivers flowing from the Sierra Nevada normally bear Academy, Yokohl (strong variant) Porterville, or Seville series (table 2). These soils formed on locally derived alluvium from andesitic and metavolcanic source areas. The Yokohl (strong variant) soil has a strongly developed red argillic horizon underlain by a thick well-cemented silica-iron duripan. The Porterville and Seville are vertisols (montmorillonitic self-churning soils showing little or no profile development) and are therefore not age-diagnostic. Their high clay content, close association with the Yokohl series, and occurrence on surfaces graded to mainstream middle unit terraces and alluvial fans, however, indicate their soil stratigraphic and time equivalence with the Yokohl-San JoaquinMadera-Snelling-Ramona soil association on the middle unit.

\section{UPPER IINIT}

The upper unit of the Riverbank Formation represents a single aggradational unit. It underlies smooth, nearly undissected terrace and alluvial fan surfaces (table 3 ) which are relatively low and confined to modern drainageways, including those of minor streams such as Dry Creek (Merced County), Bear Creek, Dutchman Creek, Deadman Creek, and Berenda Creek (pls.1 and 2; fig. 3). In the east these terraces stand slightly above early Modesto terrace surfaces, but to the west they are topped by Modesto fan deposits. In like manner they are inset $5-30 \mathrm{~m}$ into older Riverbank or Turlock Lake deposits on the upper fans but open westward and spill out over the middle Riverbank and early Riverbank fans. In many interfluve areas the contact between middle and upper unit fan remnants is marked by a decrease in slope (table 1) and degree of dissection and a change from San Joaquin to Madera or Exeter soils.

The upper unit is separated from the middle unit by a moderately developed buried soil. Like the two older units it appears to consist of an upward coarsening sequence of alluvial silt and sand, with thin pebbly or cobbly lenses near the top of the sequence. At one location in Madera County ( $\mathrm{SE}^{1 / 4} \mathrm{SE}^{1 / 4} \mathrm{sec}$. 35, T. 9 S., R $17 \mathrm{E}$., Kismet $7 \frac{1}{2}$-minute quadrangle) in roadcuts along Avenue 24 just 
west of the Road 26 intersection, the upper unit unconformably overlies the middle unit, on which a San Joaquin normal variant soil developed before burial (only the duripan and underlying Cox horizons are now preserved). The middle unit in these exposures in turn overlies the Turlock Lake, on which an eroded Cometa soil is preserved through burial. The upper unit of the Riverbank at this location underlies a smooth terrace surface higher than the early Modesto terrace at this location and slightly inset into the middle unit and the underlying Turlock Lake Formation. The upper unit, bearing a Madera soil, also overlies the middle unit, bearing a buried duripan soil, along the south bluff of the San Joaquin River about $1 \mathrm{~km}$ west of California High way $99\left(\mathrm{NE}^{1 / 4} \mathrm{NE}^{1 / 4} \mathrm{sec} .6, \mathrm{~T} .13\right.$ S., R. 19 E.; Herndon 71/2-minute quadrangle).

The characteristic Ramona ${ }^{11}$ (weak variant) soil (table 2) is formed on the upper unit at the location noted above. It has a significantly thinner and less well deveoped Bt horizon than the normal variant Ramona or Snelling formed on the middle unit. The color of the B horizon is about the same, but the Bt peds are weaker; colloidal clay is restricted to pores and thin, discontinuous skins around fragments. These weak Ramona and Snelling soils are distinguishable from the Greenfield soil formed on the lower member of the Modesto by color, horizon thickness, and other properties as summarized in table 2. Where duripan soils have developed on the upper unit (Madera, normal variant; San Joaquin, weak variant; Exeter), the Bt horizon above the duripan is thin and and contains much less pedogenic clay than the San Joaquin, normal variant, soils on the middle unit (table 2 ). The duripan itself is usually moderately cemented through only $20 \mathrm{~cm}$ or less, very weakly cemented in the $25 \mathrm{~cm}$ or so beneath the stronger pan, and then the profile passes rapidly into oxidized but otherwise unweathered parent material. Calcium carbonate seams are frequently observed within the duripan along joint surfaces. In general all upper unit soils tend to be more nearly neutral than their slightly acid counterparts formed on the middle unit.

The area immediately north of the Merced River in the southeastern part of the Turlock Lake $7 \frac{1}{1} 2$-minute quadrangle and the southwestern part of the adjacent Snelling 71/2-minute quadrangle, northeastern Merced County (pl. 2; fig. 3), is suggested as a reference area for the Riverbank Formation. All three Riverbank geomorphic surfaces are well displayed in proximity here, and the lower and middle units are exposed in several roadcuts, in superposition at one location (see above).

\footnotetext{
"The Ramona soil series (Typic Haploxeralf in Madera and Fresno Counties is a somewhat redder and browner, more alkaline counterpart of the Snelling series in Stanislaus and Merced Counties.
} 
The Modesto Formation is composed of mainstream arkosic sediments and associated deposits of local derivation laid down during the last major series of aggradational events in the eastern San Joaquin Valley. Gravel, sand, and silt were deposited as a series of coalescing alluvial fans extending continuously from the Kern River drainage on the south to the Sacramento River tributaries in the north. They occur in a wide band immediately east of the San Joaquin Valley axis and to the west of the Riverbank and older fan remnants (pl. 1). Most of the prime agricultural land and many of the major cities of the eastern San Joaquin Valley are located in young alluvial soils associated with the undissected Modesto terrace and fan surfaces. Modesto deposits overlie late Riverbank alluvium and older units as well and are locally incised or covered along modern channels by post-Modesto deposits.

Davis and Hall (1959) first used the term Modesto Formation for young fluvial deposits in eastern Stanislaus andnorthern Merced Counties, earlier recognized by Arkley (1954) on the basis of soils and landforms. The formation name has since been widely applied to deposits throughout the eastern San Joaquin Valley (Arkley, 1962a; Janda, 1965, 1966; Janda and Croft, 1967; Helley, 1967; Huntington, 1971; Shlemon, 1967a, 1967b, 1971, 1972). The term Victor Formation (fig. 2) was used by Gale, Piper, and Thomas (1939) for deposits in the Mokelumne River area that have since been differentiated into the Turlock Lake, Riverbank, and Modesto Formations. Because the Victor Formation was never clearly defined and includes deposits of significantly different age, we do not employ the name and suggest abandonment of the term.

The material of the Modesto Formation are virtually identical to those of the Laguna, Turlock Lake, and Riverbank Formations, but their association with low terraces and young fans and their moderate to slight degree of erosional modification and soil profile development clearly differentiate them from older alluvium. Modesto deposits are significantly more deeply oxidized and weathered than Holocene deposits, except for upper Modesto eolian sand, which generally displays a very weak $\mathrm{A} / \mathrm{Cox} / \mathrm{Cn}$ soil profile. A Wisconsinan age for the Modesto is indicated by (1) the youthful topography, geomorphic position, and soils, (2) the fact that the Modesto postdates the upper unit of the Riverbank Formation and is separated from it by a major period of weathering that was probably interglacial in magnitude, (3) radiocarbon dating of subsurface deposits correlated with the Modesto Formation (Janda and Croft, 1967; Croft, 1972), indicating an age greater than 9,000 years B.P. and (4) radiocarbon dates of about 14,000 and 42,000 B.P. 
on wood in the upper and lower members, respectively.

Davis and Hall (1959) gave a total thickness of $15-30 \mathrm{~m}$ for the Modesto Formation in eastern Stanislaus County. Arkley (1962a) suggested a thickness of about $40 \mathrm{~m}$ along the Merced River, and Helley (1967, fig. 39) showed about $20 \mathrm{~m}$ on the Chowchilla River fan. These figures are consistent with presently available data, but the section thickens toward each river channel, toward the San Joaquin Valley axis, and toward the south. Much evidence indicates that thickness varies considerably, especially of the upper member, and that local facies changes within the formation make specific stratigraphic descriptions almost meaningless. For example, the Modesto's type section resembles many exposures of the Modesto toward the basin but differs greatly from exposures near the foothills, where the Modesto commonly is composed entirely of sand and gravel. Near the city of Merced, the Modesto consists primarily of andesitic detritus, whereas along the major westwarddraining rivers, it is predominantly arkosic. Numerous channels within Modesto and older alluvium (Shlemon, 1971) create rapid lateral changes in texture that can often be traced only by means of subsurface information. Similar facies changes occur in the older Laguna, Turlock Lake, and Riverbank Formations but are less evident owing to lack of preservation.

We recognize two informally named members of the Modesto Formation on the basis of topographic expression and position and soil development. In places, these two members can be divided into two or more subunits on the basis of similar evidence (fig. 4; pl. 2). In some areas, these subunits are associated with mappable geomorphic surfaces (alluvial fans or terraces).

The type section of the Modesto Formation apparently includes both its lower and upper members. This section is redescribed below because much of the material originally identified as Modesto is actually Riverbank alluvium exposed beneath an eroded buried soil at about 4.9-5.2 m depth.

\section{Type section, Modesto Formation}

\footnotetext{
Location: series of cuts exposed in private road in NW1/SW/4 sec. 1, T. 4 S., R. 9 E., down south bluff of Tuolumne River, just east of Mitchell Road Bridge (note slightly different location from that of Davis and Hall, 1959, p. 20, which is west of the bridge and presently overgrown by brush) Ceres $71 / 2$-minute quadrangle, Stanislaus County (fig. 1)
}

Top of bluff; smooth surface of late Modesto alluvial fan about $17 \mathrm{~m}$ above river level; surface appears to be disturbed in most places. 


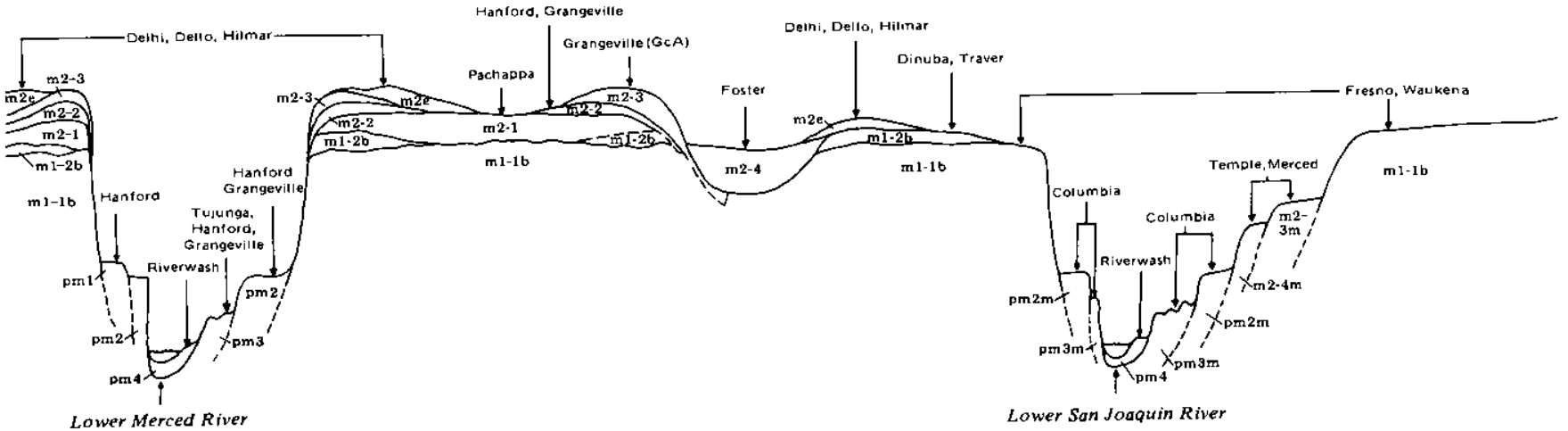

FiguRE 4. Schematic geologic section across the Merced River west of Stevinson, Merced County, showing relation of soils to Modesto and post-Modesto deposits and geomorphic surfaces. 
Type section, Modesto Formation-Continued

Unit

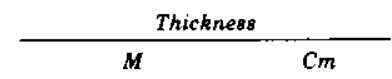

Modesto Formation:

Upper member:

8. Fine to medium sand; contains scattered granules; light brown; appears massive but stratification may have been destroyed by soil development; abrupt basal contact marked by platy calcium carbonate several centimeters thick and thin lenses of fine gravel and sand with orangish oxidation, all within a 5 -cm zone (unconformity?)

Unconformity(?).

Lower(?) member:

7. Coarse silt and interstratified fine sand somewhat more compact than unit 8 above; light gray to gray with yellowbrown and brown mottling throughout; oxidized, strongly calcareous root, crevice, and burrow(?) fillings; becomes sandier toward base except for $20-30-\mathrm{cm}$ silt bed just above unit 3 ; moderately well stratified; silt beds show weak parallel lamination; upper part has calcium carbonate cement (probably pedogenic and related to stripped buried soil(?) formed on lower member); somewhat indurated

6. Fine sand; light gray to buff with very prominent yellowish brown to reddish brown oxidation marking coarser beds and laminae; well stratified and internally laminated.

5. Silt with interstratified fine sand; similar to unit 2 above but lacks abundant root casts

4. Medium sand with interstratified fine sand; medium gray with some yellowish-brown oxidation along laminae; fairly well stratified and crosslaminated; appears to be lenticular

3. Silt with some fine sand; greenish gray with brown to reddish-brown mottling throughout, especially toward base; slightly indurated; generally massive with some cross-stratification (30-cm beds); distinct boundary at base when viewed at a distance, but difficult to pinpoint on the outcrop owing to water table alteration along unconformity

Total thickness of Modesto Formation 5.0 Unconformity.

Upper unit:

2. Interstratified sand and silt, as described 
Type section, Modesto Formation-Continued

\begin{abstract}
Unit
by Davis and Hall (1959, p. 20-21, units $10-21$ ); upper $64 \mathrm{~cm}$ is stripped B2 horizon of buried soil similar to the Snelling, weak variant, but somewhat less well devel. oped; in places there is a weak iron.silica duripan about $35 \mathrm{~cm}$ thick underlain by a platy $10-\mathrm{cm}$ transitional zone to a $45-\mathrm{cm}$ oxidized Clox horizon; at all locations this buried soil is less well developed than the relict upper Riverbank paleosol but better developed than soils formed on the lower member of the Modesto
\end{abstract}

1. Silt and sund; not well exposed; base of river bluff; surface of post-Modesto II terrace

Total thickness of Riverbank Formation

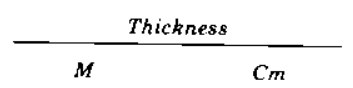

5.5

5.5

11.0

The weak buried soil (?) between the lower and upper Modesto in the type section has demonstrable counterparts on the lower fans west of Madera (see map units of Ulrich and Stromberg, 1962)-for example, Grangeville, Hanford, Pachappa (on upper member) over hardpan (buried Fresno soil formed on lower member). The presence of these moderately to weakly developed soils between the lower and upper members of the Modesto and recognizable differences in relict soils formed on the lower member and those formed on the upper member suggest a significant period of weathering and nondeposition between two alluvial events. Judging from the development of the intra-Modesto soil, this time interval must have been longer than post-Modesto time but shorter than the RiverbankModesto hiatus.

\section{LOWER MEMBER}

Alluvial fans associated with the lower member of the Modesto Formation cover an extensive part of the northeastern San Joaquin Valley but appear to be mostly covered by younger fan deposits south of Fresno and by younger eolian sand on the Merced River fan toes. The lower member is also thicker than the upper member: the lower member is $25 \mathrm{~m}$ thick or more, whereas the younger alluvial fill rarely exceeds $10 \mathrm{~m}$, even along channelways.

The lower member is associated with two terrace surfaces (representing erosional or depositional phases of the lower member) along the Chowchilla River. There may have been two early Modesto alluvial fills (see discussion of age below), or the later surface may be a strath cut into the lower member. Stringers of less 
well developed basin soils (Traver and Dinuba; Natric and Typic Haploxeralfs) passing through areas of more strongly developed Fresno, Waukena, and Pond soils (Natric Durixeralfs and Typic Natrixeralfs) may represent erosional channels within flood basin deposits of the same age or a younger phase of lower member deposition (pl. 2; fig. 4).

Although the lower member of the Modesto is composed primarily of sand, a substantial proportion of the deposits is well-stratified silt and fine sand, especially near the base of the unit and toward alluvial fan toes. Some of this fine sediment may be of local lacustrine origin, like that of the Laguna, Turlock Lake, and Riverbank Formations. Gravel also makes up a significant part of the lower member, particularly close to the foothills near or above the lower Modesto fan apexes. The lower member includes a large amount of locally derived detritus, largely of andesitic and metamorphic origin, from drainages heading in the foothills.

The surfaces of the lower member bear a variety of soils, the most characteristic of which are the Borden (Natric Hapoxeralf) and Greenfield (Typic Halpoxeralf) series. These soils have minimal argillic horizons with $10 Y R$ to $7.5 Y R$ hues. The profiles are shallower, less acid, and not as red as those developed on Riverbank alluvium, and they lack silica-iron duripans (table 2). Along the Chowchilla River (N1/2 sec. 8, T. 9 S., R. 17 E., Le Grand 71/2-minute quadrangle) two lower member terraces bear Borden soils with somewhat different degrees of profile development. Calcium carbonate silica-cemented duripans with overlying argillic horizons (Fresno soil series) have developed under impeded drainage in early Modesto overbank and flood basin rim deposits. A generalized description of the Greenfield soil series, as developed on uneroded well-drained arkosic alluvial sand, is given below:

0-46 cm A or Ap Sandy loam, brown $(10 Y R 5 / 3 \mathrm{~m})$; medium to coarse subangular blocky; clods moderately strong

46-102 $\mathrm{cm} \quad$ Bt Lightsandy clay loam, brown to pale-red-brown $(7.5 Y R$ or $10 Y R$ hue, 4 chroma); medium to coarse subangular to angular blocky peds, moderately strong to strong; clay fills interstitial pores lines tubular pores, and thinly coats some clasts but not ped surfaces

$102-150 \mathrm{~cm} \quad$ Clox Sandy loam or loamy sand, brown or yellowish-brown (10YR $5 / 3$ to $5 / 4 \mathrm{~m}$ ); oxidized but otherwise only slightly weathered and only slightly aggregated

$150 \mathrm{~cm}+\quad \mathrm{Cn} \quad$ Sand, single-grain; unweathered and unconsolidated; light gray to pale brown $(10 Y R 5 / 2$ or $6 / 2 \mathrm{~m})$

The Ryer soil series (Typic Haploxeralf) is commonly mapped on alluvium of andesitic source associated with sidestream terraces 
that grade to levels slightly below the lower member surfaces on the mainstream. (pl. 2; fig. 3).

Recognizable facies of early Modesto age include channel deposits, interdistributary and floodbasin deposits, colluvium, and eolian sand, the last deposited widely over the Merced and Tuolumne River fan toes and along the south side of eariy Modesto terraces. The Atwater soil series (Typic Haploxeralf), which has a distinct textural B horizon, is mapped on the lower Modesto eolian sand. These eolian materials are better sorted than the alluvial deposits from which they were apparently derived but much less well sorted and rounded than typical eolian dune sands, suggesting a short transport distance. Their geographical location close to the apparent fan and terrace source areas also indicates limited transport.

The age of the lower member is probably Altonian (early and middle Wisconsinan). A tentative open-system uranium-series age $(29,407 \pm 2,027$ years) on bone in basin alluvium north of Modesto bearing a Dinuba soil (E. L. Begg, oral commun., 1975) provides a probable minimum age for the lower unit. Wood at a depth of 15-16 $\mathrm{m}$ in nearby lower Modesto flood basin deposits (Fresno surface soil) about $6.25 \mathrm{~km}$ southeast of the Tuolumne-San Joaquin River confluence gives a radiocarbon age of $42,400 \pm 1,000$ years B.P. ${ }^{12}$ Uranium-trend dating of a Greenfield soil formed on an early Modesto terrace south of the Merced River near Cressey, however, has yielded a tentative age of $95,000^{\prime} 45,000$ years B.P. (J. N. Rosholt, written commun., 1979). Although this date's error bars nearly overlap the above radiocarbon age, it appears likely that the lower member encompasses a substantial span of early and middle Wisconsinan time and perhaps more than one period of alluviation (see p. 56). Flood basin deposition may have continued after deposition ceased on terraces and upper fans near the foothills. Glacial-outwash facies of the lower member of the Modesto are probably correlative with the end of isotope stage 4 of the marine climatic record (see Marchand, 1977), possibly extending into the earlier part of isotope stage 3 (Broecker and Van Donk, 1970; Hays and others, 1976).

IJPPER MEMBER

The upper member of the Modesto Formation is exposed in a

\footnotetext{
${ }^{12}$ Radiocarbon determination (USGS-429) performed in the laboratories of the U.S. Geological Survey, Menlo Park, Calif., by Stephen W. Robineon. Sample collected by Jerry Hill and submitted by Kenneth Schmidt. Exact location of sample: W1/2NW $1 / 4$ aec. 34., T. 4 S., R. 8 E., Brush Lake $7 \frac{1}{2}$-minute quadrangle. Observation well about $0.16 \mathrm{~km}$ south of Keyes Road.
} 
series of up to four terraces and fans associated with major Sierra Nevada rivers (including the Fresno and Chowchilla Rivers) tributary to the lower San Joaquin River (pl. 1). We have been able to distinguish only one correlatable upper member terrace along smaller streams heading in the foothills. On most of the major rivers, terraces associated with the lower member open up into fans $2-20 \mathrm{~km}$ east of the lower San Joaquin River. The upper member may be recognized by its topographic position between the lower post-Modesto terrace and flood-plain surfaces, and the higher terraces and fan surfaces of the lower member and the Riverbank Formation. Unlike the post-Modesto surfaces, the longitudinal profiles of the upper member surfaces converge significantly downstream toward the modern river profiles (table 1).

The upper member includes deposits comprising several facies, many of them mappable. It is primarily composed of Sierran arkosic coarse sand and gravel that gives way to fine sand and silt near the lower San Joaquin River. Typical exposures of crossbedded coarse sand and gravel may be seen in the Munn and Perkins quarry (SW1/4 sec. 15, T. 2S., R. 9 E.), on the north side of the Stanislaus River and $5 \mathrm{~km}$ southeast of Escalon (Escalon $71 / 2$ minute quadrangle). Some finer grained deposits of the lower member are also exposed beneath the upper member toward the east end of the quarry. Locally derived material, usually of andesitic or metamorphic source, is associated with sidestream terraces graded to the lowest of the mainstream terraces and is considered part of this member. The Wyman,Marguerite, Capay, Bear Creek, and Honcut (mostly Typic Haploxeralfs and Typic Xerochrepts) soil series, which have somewhat more strongly developed profiles than those formed on arkosic sediments of the same age, are commonly mapped on these sidestream terraces. Eolian sand bearing relatively weak thin A/Cox/Cn Delhi and Hilmar soil profiles (Typical Xeropsamment; Aeric Halaquept) overlies alluvium of all four upper member terraces; the associated dunes are truncated by post-Modesto terrace-flood plain surfaces (pl. 2; fig. 4), indicating deposition during latest Modesto time. These eolian deposits are very extensive, especially on the toe of the Merced River fan. Young colluvial deposits in the foothills grade into the youngest late Modesto terraces and bear similar soils (Harden and Marchand, 1980).

At least four terrace-fan surfaces are associated with the upper member. These surfaces may represent separate alluvial fills, in which case they could be designated as subunits of the upper member, or the younger surfaces may be erosional features cut across one early fill. Gordon Huntington (oral commun., 1976) 
reports evidence of four separate fills associated with the Kings River in Fresno County, and along the Tuolumne and Stanislaus Rivers several of the terraces appear to open onto fans, suggesting separate fills. In this report we refer to the four surfaces as representing four erosional or depositional phases. The geomorphic surface associated with phase 1 (the oldest) was probably the most extensive originally but seems in some areas to have been modified by phase 2 erosion or covered by phase 2 deposits. Phase 1 surfaces are best preserved on the upper parts of late Modesto fans and as the highest upper member fill terraces, for example along the Stanislaus River near the towns of Riverbank and Oakdale. Phase 2 surfaces are most readily recognizable as channels cut into phase 1 surfaces-for example, along the lower Merced River (pl. 2; fig. 4), on the south side of the San Joaquin River immediately west and southwest of Herndon (Herndon channel), and on the west side of the Kings River southwest of Sanger (Sanger $7^{1 / 2-m i n u t e ~ q u a d r a n-~}$ gle). The alluvium in the channels lies $2-5 \mathrm{~m}$ below the surrounding phase 1 fan surface and contains coarser material than the adjacent fan, suggestive of a separate alluvial fill. Phase 3 is recognizable as a terrace between phase 2 and phase 4 terraces on the Tuolumne and Stanislaus Rivers and as a few small terrace remnants along the San Joaquin River. Phase 4 terraces (youngest) form narrow benches along the present rivers, often closer in elevation to the Holocene flood plain terraces than to phase 2 or 3 surfaces. Near fan toes, crosscutting soil units with associated leveelike topography suggest successive deposition (pl. 2; fig. 4). All four terraces can be crossed in sequence along Henry Road north of the Stanislaus River (Escalon 71/2-minute quadrangle), 5-6 km southeast of Escalon, but the phase 1 and 2 terraces here are veneered by upper Modesto eolian sand.

The best developed upper-member soils (Pachappa, Oakdale, Hanford, strong variant); Natric Haploxeralf, Mollic Haploxeralf, Typic Haploxeralf) usually associated with the oldest surface (phase 1) have thick AC or weak cambic B horizons (table 2) overlying oxidized $\mathrm{C}$ horizons. Their $\mathrm{B}$ horizon hues of $10 Y R$ tend toward $7.5 Y R$ in places, especially toward the north in Stanislaus County, and their maximum chromas are 4 . Interstitial and tubular pore fillings of clay are common, but the pores usually less than half filled and the thin clay coatings are only locally evident on the surface of clasts. Soil structure is fine to coarse subangular blocky, with weak to moderate ped strength. Slightly less developed Hanford, Grangeville, Cajon, Wunjey, and Visalia soils with deep $\mathrm{Ap} / \mathrm{AC} / \mathrm{C} 1 \mathrm{ox} / \mathrm{Cn}$ profiles (table 2 ) characterize phase 2 and 3 surfaces. Tujunga and some coarse Hanford and Honcut soils with 
similar but thinner profiles occur on the more restricted stringers and narrow terraces associated with the youngest surface (phase 4). On the Chowchilla and Fresno River fans, the four phases may be interpreted from crosscutting patterns shown by the soil map units of Ulrich and Stromberg (1962): Pachappa and Chino on phase 1; Grangeville and Hanford on phase 2; Cajon, Visalia, Wunjey, and Hanford (Hfa) on phase 3, and Tujunga on phase 4. Although soil formation on the four terrace-fan surfaces changes slightly with age, the influence of even minor differences in parent material and climate tends to overshadow the effects of time. Welldrained soils formed in comparable parent materials tend to be slightly better developed toward the north (Stanislaus and Mokelumne River terraces) and toward the foothills, perhaps owing in part to the increased effective leaching potential (precipitation minus actual evapotranspiration) but primarily to the higher percentage of metavolcanic and Mehrten andesitic detritus to the north and east.

The time interval between the deposition or erosional planation that formed the terraces was apparently very brief. The relict soils formed on the four surfaces do not differ greatly and buried late Modesto soils formed on alluvium of the Mokelumne and Cosumnes Rivers are preserved under alluvium and intertidal deposits laid down in response to Holocene sea level rise in the San JoaquinSacramento Delta about 6,000 B.P. (Atwater, 1979; Shlemon and Begg, 1975; Harden and Marchand, 1980).

The age of the upper member is probably bracketed by carbon- 14 ages of approximately 27,000 and 9,000 years B.P. on wood below and above the subsurface A clay (Janda and Croft, 1967; Croft, 1968,1972 ). A new carbon-14 age of $14,100 \pm 200$ years ${ }^{13}$ on wood in upper members glacial outwash sand about $12 \mathrm{~m}$ beneath the Kern River alluvial fan at Bakersfield corresponds almost exactly with a subsurface carbon-14 age of $14,060 \pm 450$ years B.P. (W-1650; Ives and others, 1967; Croft, 1968) on wood at the top of lacustrine sediment derived from the Sierra Nevada within the upper part of the A clay about $40 \mathrm{~km}$ to the west. Outwash fan deposition and basin lakes were therefore contemporaneous in late Modesto time, as they were when the Friant Pumice Member of the Turlock Lake Formation was laid down over the Corcoran Clay Member. The upper Modesto appears to be correlative with the upper part of the subsurface A clay and with the closing phases of the Tioga

\footnotetext{
13USGS-38. Radiocarbon analysis performed in the laboratories of the U.S. Geological Survey, Menlo Park, Calif. by Stephen W. Robinson. Sample collected by Steve Soenke. Exact locstion: Gosford 71/2-minute quadrangle, SW $1 / 4$ SW1/4 sec. 35, T. 25 S., R. 27 E., on boundary with NW1/4NE1/4 sec. 2.
} 
Glaciation of the Sierra Nevada (Janda and Croft, 1967; Marchand, 1977), which ended about 9,000 years ago (Adam, 1967). Pending further radiocarbon results we suggest an age range from about 14,000 to 9,000 years B.P. for the upper Modesto.

\section{POST-MODESTO DEPOSITS}

Holocene deposits post-dating the Modesto Formation in the northeastern San Joaquin Valley are located close to modern drainageways; most small foothill streams, except those near Merced, have not built post-Modesto fans. In general, post-Modesto deposits are relatively thin and essentially unweathered. Holocene alluvium of four ages (pl. 2; fig. 4) is recognized along most of the major rivers by topographic expression and position and, secondarily, by minor differences in soil profile development (table 2). These Holocene deposits are informally designated postModesto I, II, III, and IV, respectively.

Deposits tentatively assigned to the post-Modesto I unit in the northeastern San Joaquin Valley underlie low terraces or high flood plains about 6-8 $\mathrm{m}$ above base flow levels along the Stanislaus, Tuolumne, Merced, and San Joaquin Rivers. Post-Modesto I terraces are seen in few places and appear to have been buried or removed by erosion in most places before or during the development of the post-Modesto II terrace-flood plain surface. They appear to converge very slightly downstream toward the present river profile. The post-Modesto I terrace occurs locally along the lower Merced River (pl. 2; fig. 4), where it stands slightly above the more extensive post-Modesto II terrace. The older surface is also evident along the south side of the Tuolumne River in the SW $1 / 4$ SW $^{1 / 4}$ sec. 33 , T. 2 S., R. 11 E., Waterford $71 / 2$-minute quadrangle, where it occupies an elevation between post-Modesto II and late Modesto terraces. The post-Modesto I deposits bear a soil with a Cox horizon tending toward an AC horizon. The soil profile does not appear to be as deep as that of the post-late Modesto soils, but good exposures in post-Modesto I materials are rare. Low terraceflood plain surfaces along the lower San Joaquin River bear dark, clayey Temple and Merced soils which are in places buried by post-Modesto II alluvium bearing Columbia soils. Post-Modesto I alluvium along Dry Creek north of the Merced River, buried by post-Modesto II deposits bearing a weak Honcut soil, is incised into a latest Modesto terrace bearing a Wyman soil. Lithologic contrasts observed in soil pits excavated into these Dry Creek terraces indicate that the late Modesto, post-Modesto I, and postModesto II deposits represent separate alluvial fills this area.

Post-Modesto I deposits in the northeastern San Joaquin Valley 
may be correlative with early Holocene deposits elsewhere in the Central Valley of California. Extensive fan alluvium at Davis, west of Sacrmento, bears an $\mathrm{A} / \mathrm{Cox} / \mathrm{Cn}$ soil (Yolo series) that contains charcoal and organic carbon dated at about 4,000 years B.P. (Shlemon and Begg, 1972). The soil is buried by $1-2 \mathrm{~m}$ of younger alluvium bearing a Sycamore soil and overlies an older buried soil (Capay series) showing an $\mathrm{A} / \mathrm{AC} / \mathrm{Cox} / \mathrm{Cn}$ profile whose A horizon contains charcoal and organic carbon dated at 9,150 \pm 650 years B.P. The deposits were therefore laid down in some time interval between 9,000 and 4,000 years ago. Early man sites flanking the Buena Vista lakebed west of Bakersfield are situated on lacustrine sediment associated with a former higher stand of the lake. Mollusk shells from the shoreline have yielded carbon-14 ages ranging from 7,600 to 8,200 years B.P. (Buckley and others, 1968, p. 278; Hubbs and Bien, 1967, p. 288).

Post-Modesto II deposits lie beneath a lower terrace-flood plain surface, ${ }^{14}$ overtopped by occasional high floods before the construction of dams on the rivers draining the Sierra Nevada, about 3-5 $\mathrm{m}$ above river level. This terrace-flood plain surface can be traced continuously along sidestreams and Sierra Nevada rivers into a comparable level along the lower San Joaquin River. Small alluvial fans have developed near the confluence of the Sierra Nevada rivers with the lower San Joaquin (pl. 1 and 2), but these fans are almost an order of magnitude smaller than the late Modesto fans (pl. 1). Unlike the post-Modesto I and all older terraces, the post-Modesto II terraces do not converge significantly downstream toward the modern stream profile (table 1).

The width of the post-Modesto II surface is normally less than $200 \mathrm{~m}$, but on the Merced River west of Snelling the surface widens to over $5 \mathrm{~km}$. The extent of this surface, the thickness of coarse sand and gravel underlying it, as seen in many quarries along the Merced and other rivers, and the absence of any evidence of Holocene tectonism in the region suggest that the post-Modesto II deposits may reflect late Holocene (Neoglacial) climatic events in the Sierra Nevada, which could have altered the load-to-discharge ratio of the rivers to the point at which they could transport and redeposit coarse material. Alternatively, these deposits could simply represent the reworking of pre-Holocene alluvium by major floods unrelated to a significant change in climate. Historic floods, however, do not appear to have caused major erosion, transport, or

\footnotetext{
"The term "terrace-flood plain" is applied to this surface to emphasize the prehistoric materials that underlie it, its prehistoric origin, and the fact that this same surface has also been modified both erosionally and depositionally by historic floods.
} 
deposition of coarse material beyond their present channels.

Recognizable and in some places mappable post-Modesto II deposits include channel, point bar, levee, crevasse splay, interdistributary, and flood basin alluvium. Some local bodies of eolian sand, probably reworked from late Modesto eolian deposits, mantle post-Modesto I and II terraces. These sand bodies are not extensive but show some dunal topography indicative of a young age. In a few areas, agricultural practices have reactivated dunes.

The most typical soil series on post-Modesto II surfaces are the Tujunga (Typic Xeropsamment), Grangeville (Fluraquentic Haploxeroll), and Foster on arkosic alluvium along the major rivers; the Honcut and Yolo on locally derived alluvium associated with drainages tributary to the major rivers; and the Columbia (Aquic Xerofluvent) on mixed arkosic and Coast Range-derived detritus along the lower San Joaquin River. These soils usually show only a shallow A/Cox/Cn profile (table 2 ). A slight increase in bulk density (1.5-1.6 compared with about 1.3 in the $\mathrm{Cn}$ ) occurs at the top of the Cox horizon, but otherwise there is no indication of a transitional AC horizon. Fresh, loose, stratified parent material is normally found within a meter of the surface. Reaction is slightly alkaline, usually close to $\mathrm{pH} 8$. Weak buried Temple soils formed on post-Modesto I or upper Modesto deposits beneath post-Modesto II deposits west of Madera along the lower San Joaquin River show that the post-Modesto II is significantly younger than the postModesto I or latest Modesto (see map units of Ulrich and Stromberg, 1962: Foster, Grangeville, Columbia soils over Temple soils). A buried $\mathrm{A} / \mathrm{Cox} / \mathrm{Cn}$ post-Modesto I soil beneath post-Modesto II alluvium along Dry Creek in Merced County provides further evidence of a significant time gap between the two units.

The post-Modesto II deposits appear to be prehistoric but late Holocene in age, judging from weak soil development and a few radiocarbon dates. A $\log$ buried about $5.2 \mathrm{~m}$ beneath the postModesto II alluvial surface along the Tuolumne River ( $\mathrm{SE}^{1 / 4} \mathrm{SW}^{1 / 4}$ sec. 33, T. 3 S., R. 11 E., Waterford 71/2-minute quadrangle) in coarse gravelly alluvium has yielded a carbon- 14 age of $370 \pm 200$ years. ${ }^{15}$ Because of the very young age and the fact that quarry workers recovered the sample, this date should be regarded with caution.

Radiometric age determinations on material from Indian occupation sites associated with post-Modesto II surfaces and deposits have yielded somewhat older and probably more reliable

\footnotetext{
${ }^{15}$ Radiocarbon determination (W-3378) performed by Meyer Rubin in the laboratoriea of the U.S. Geological Survey, Reston, Va.
} 
ages. ${ }^{16}$ Charcoal $1.6 \mathrm{~m}$ below a terrace-flood plain surface bearing a Columbia silt loam surface soil along the Feather River south of Oroville in the Sacramento Valley has given a carbon-14 age of $3,020 \pm 130$ years (GX 2191). Charcoal from a low terrace-flood plain surface along French Camp Slough southwest of Stockton has yielded a carbon-14 date of $2,020 \pm 160$ B.P. (GX 1926), but bone collagen from the same location gave a 2,985 160 -year age (GX 1925). The bone collagen age is probably more reliable than the charcoal because of possible mixing of younger charcoal from above. A University of California, Davis, uranium-thorium age determination on the same bone material yielded a 4,440 230 -year age. From this information, it appears that the post-Modesto II deposits are about 3,000 years old.

Deposits of post-Modesto III age include fluvial sand, silt, and clay associated with a distinctive and well-preserved constructional topography of abandoned meander loops and arcuate levees 2-4 $\mathrm{m}$ above present river level along the lower reaches of the Sierra Nevada rivers and along the lower San Joaquin River. They are confined to narrow benches and are therefore not readily recognizable on streams heading in the foothills, including the Chowchilla and Fresno Rivers. The post-Modesto III geomorphic surface is a part of the modern flood plain but stands slightly above the modern channelways. The deposits range from gravels near the foothills to fine silt and clay along the San Joaquin River. Soils formed on this surface display very immature $(\mathrm{A} / \mathrm{Cn})$ profiles; they not only lack AC horizons but also show little or no Cox horizon development (table 2). Even the A horizons do not appear to be fully developed. The weakest variant of the Columbia soil series is mapped along the lower San Joaquin River on mixed parent materials, and the weakest variants of the Tujunga, Grangeville, and Foster series are mapped on arkosic alluvim along the Sierran rivers. Weak variants of the Honcut and Marguerite soils occur along streams that head in the foothills.

The age of the post-Modesto III deposits is unknown but probably spans the last few hundred years. Post-Modesto III levees support large trees that are probably more than 80-100 years old. In the Snelling area along the Merced River, late 19th century dredge tailings truncate post-Modesto III channelways and levees.

Modern deposits (post-Modesto IV) include unvegetated channel and point bar alluvium along all major streams, modern overbank facies exist in most places but are too thin to map. Lacustrine,

\footnotetext{
15All information in this paragraph supplied by E. L. Begg. Department of Land, Air and Water Resources, Soils and Plant Nutrition Section, Univergity of California, Davis, written commun., 1977.
} 
swamp, and marsh deposits are presently accumulating in poorly drained areas on the alluvial fan toes, especially between and along the margins of late Modesto sand dunes and fan distributaries. In oxbow lakes on river flood plains, near the edge of the Delta where Holocene sea level rise caused alluviation of the lower Mokelumne and Cosumnes Rivers, lakes and swamps have formed where tributary gullies have been blocked by mainstream aggradation. A few small areas of modern reactivated sand dunes may be found on the Merced River fan, usually within areas of stabilized late Modesto dunes. Post-Modesto IV deposits are thin and not laterally extensive. All of these modern deposits underlie presently active depositional surfaces and show neither A nor Cox soil horizons.

\section{SUMMARY}

The Tertiary formations of the northeastern San Joaquin Valley differ markedly in lithology and are similar only in that they all include fluvial gravel and fine sediment derived from the Sierra Nevada. The Ione, Valley Springs, Mehrten, and Laguna Formations dip southwest at progressively lesser gradients, and their strike changes from N. $50^{\circ} \mathrm{W}$. for the Ione to N. $30^{\circ} \mathrm{W}$. for the North Merced Gravel (table 1); all contain at least some coarse materials. Their deformation appears to have been closely related to tectonic events in the Sierra Nevada; their deposition may have been in response to tectonism, volcanism, and perhaps climatic events as well (Marchand, 1977).

The members of the Quaternary alluvial sequence (Turlock Lake, Riverbank, and Modesto Formations) are relatively undeformed, lithologically indistinguishable (with some minor exceptions), and appear to have been deposited in response to climatic rather than tectonic events. The North Merced Gravel, which separates the Tertiary and Quaternary sequences, differs from both older and younger deposits in that it is thin and represents gravel deposits on a surface of erosion and transport rather than an alluvial fill.

The Laguna, Turlock Lake, Riverbank, and Modesto deposits are similar in four respects: (1) the arkosic nature of their sand and silt fraction (although the Laguna contains significant amounts of volcanic and metamorphic detritus), (2) a tendency toward upward coarsening sedimentation cycles (prograding alluvial fans?), (3) deposition as sequential overlapping alluvial terrace and fan systems, and (4) probable glacial origin of much of the sediment (Janda, 1965, 1966; Marchand, 1977). The four formations differ in age, topographic expression, geomorphic position, post-depositional soil development, and geographical occurrence. Some minor litho- 
logical differences in present surface exposures are apparent although not necessarily significant: well-stratified silt and fine sand seem to be more commonly exposed in both units of the Turlock Lake and the Modesto than in the three units of the Riverbank; gravel tends to be common in both members of the Modesto and in the upper part of the lower Turlock Lake but is less abundant in the upper unit of the Turlock Lake and in the Riverbank. The gravel in the upper member of the Modesto is confined to relatively narrow channels and may reflect reworking of coarse fragments from older deposits.

The units of the Turlock Lake, Riverbank, and Modesto Formations take the form of a series of terraces opening westward into alluvial fans, each terrace-fan system appearing successively west of the previous one and filling an incision into it. Soil profile development and degree of erosional modification of the original depositional surface decrease basinward and streamward on the younger, lower geomorphic surfaces. ${ }^{17}$ The soil and topographic discontinuities and superpositional sequences are sufficiently well defined to permit division of the Turlock Lake Formation into two units, each with several subunits, the Riverbank into three units, and the Modesto Formation into two members, each having two to four phases. Similar criteria may be used to differentiate postModesto deposits into four age subdivisions.

Soil development in well-drained relatively uneroded arkosic parent materials of similar grain size distribution shows several trends with increasing age (table 2) (see also Harden and Marchand, 1977): (1) increased thickness of horizons and depth to fresh parent material, (2) redder hues, (3) brighter chromas, (4) lower $\mathrm{pH}$, (5) sharper definition of horizon boundaries and more horizons, and (6) sequential development of Cox, AC, cambic B, weak argillic horizons and finally, in soils formed on Turlock Lake, a very strong argillic horizon. Pedogenic clay and iron oxide first bridge grains, then fill, interstitial and tubular pores, then cover clast surfaces, and finally extend over ped surfaces and to greater depth. In duripan soils, the time sequence involves a change from calcium carbonate silica duripan with no overlying $\mathrm{B}$ horizon $(\mathrm{El}$ Peco series in Fresno County) to a fairly strong calcium carbonatesilica pan beneath a good argillic horizon (Fresno series), to a relatively weak silica-iron duripan soil with calcium carbonate seams (Madera series), and finally to red, acid, strongly developed

\footnotetext{
${ }^{17}$ Soil properties also show contrasts due to drainage, position on slopes, parent material, and, over broad areas, to contrasting climate and vegetation.
} 
silica-iron duripan soil with a very strong argillic horizon above the pan (San Joaquin, normal and strong variants). The older Redding duripan soils on the North Merced Gravel and the China Hat Gravel Member of the Laguna Formation differ from the San Joaquin in that they are usually redder, much more acid, show brighter chromas and thicker, more continuous clay coatings on ped surfaces, and frequently display translocated clay well below the hardpan, suggesting engulfment of an older argillic horizon by later silica-iron cementation.

\section{REFERENCES CITED}

Adam, D. P., 1967, Late-Pleistocene and Recent palynology in the central Sierra Nevada, California, in Cushing, E. J., and Wright, H. E., Jr., eds., Quaternary paleocology: New Haven, Yale Univ. Press, p. 275-301.

Allen, V. T., 1929, The Ione Formation of California: California Univ. Dept. Geol. Sci. Bull., v. 18, p. 347-448.

Anderson, F. M., 1911, The Neocene deposits of the Kern River, California and Temblor basin: Calif. Acad. Sci. Proc., 4 th ser., v. 2, p. 95.111.

Arkley, R. J., 1954, Soils of eastern Merced County: California Univ. Agr. Expt. Sta. Soil Survey, no. 11, $174 \mathrm{p}$.

1962a, The geology, geomorphology, and soils of the San Joaquin Valley in the vicinity of the Merced River, California in Geologic guide to the Merced Canyon and Yosemite Valley: Calif. Div. Mines and Geology Bull. 182, p. $25 \cdot 31$.

$1962 b$, Soil survey of the Merced area, California: U.S. Dept. Agriculture Soil Survey Ser. 1950, no. 7, 131 p.

1964, Soil survey of the eastern Stanislaus area, California: U.S. Dept. Agriculture Soil Survey Ser. 1957, no. 20, 160 p.

Arkley, R. J., and Brown, H. C., 1954, The origin of mima mound (hogwallow) microrelief in the far western states: Soil Sci. Soc. America Proc., v. 18, p. 195-199.

Atwater, B. F., 1979, Attempts to correlate late Quaternary climatic records between San Francisco Bay, the Sacramento-San Joaquin Delta, and the Mokelumne River, California: unpublished Ph.D. dissertation, Univ. of Delaware, 214 p.

Bandy, O. L., and Wilcoxon, J. A., 1970, The Pliocene-Pleistocene boundary, Italy and California: Geol. Soc. America Bull., v. 81, p. 2939-2948.

Bartow, J. A., and Doukas, M. P., 1976, Geology of the Oil Center, Rio Bravo Ranch, Lamont, and Edison quadrangles, California: U.S. Geol. Survey Open-File Report 76-592, 1:24,000.

Bartow, J. A., and Helley, E. J., 1979, Preliminary geologic map of Cenozoic deposits of the Folsom area, California: U.S. Geol. Survey open-file report 79-550, scale $1: 62,500$.

Berggren, W. A., 1972, A Cenozoic time-scale-some implications for regional geology and paleobiology: Lethaia, v. 5, no. 2, p. 195-215.

Birkeland, P. W., 1974, Pedology, weathering, and geomorphological research: New York, Oxford Univ. Press, 285 p.

Broecker, W.S., and Van Donk, Jan, 1970, Insolation changes, ice volumes, and the $\mathrm{O}^{18}$ record in deep-sea cores: Rev. Geophysics Space Physics, v. 8, no. 1, p. $169 \cdot 198$.

Buckley, J. D., Trautman, M. A., and Willis, E. H., 1968, Isotopes radiocarbon measurements VI: Am. Jour. Sci. Radiocarbon supp., v 10, no. 2, p. 278 
Creely, R. S., 1965, Geology of the Oroville quadrangle, California: Calif. Div. Mines and Geol. Bull, 184, 86 p.

Croft, M. G., 1968, Geology and radiocarbon ages of late Pleistocene lacustrine clay deposits, southern part of San Joaquin Valley, California, in Geological Survey research 1968, chapter B: U.S. Geol. Survey Prof. Paper 600-B, p. B151-B156.

1972 , Subsurface geology of the late Tertiary and Quaternary water-bearing deposits of the southern part of the San Joaquin Valley, California: U.S. Geol. Survey Water-Supply Paper 1999-H, 29 p.

Dalrymple, G. B., Cox, Allen, and Doell, R. R., 1965, Potassium argon age and paleomagnetism of the Bishop Tuff, California: Geol. Soc. America Bull, v. 76, p. 665-674.

Davis, P., Smith, J., Kukla, G. J., and Opdyke, N. D., 1977; Paleomagnetic study at a nuclear power plant site near Bakersfield, California: Quaternary Research, v. 7, p. 380-397.

Davis, S. N., and Hall, F. R., 1959, Water quality of eastern Stanislaus and northern Merced Counties, California: Stanford Univ. Pubs. Geol. Sci., v. 6, no. 1, 112 p.

Dibblee, T. W., Jr., 1973, Stratigraphy of the southern Coast Ranges near the San Andreas fault from Cholame to Maricopa, California: U.S. Geol. Survey Prof. Paper 764, 45 p.

Ely, R. W., Grant, T. A., and McCleary, J. R., 1977, Exhumed early Tertiary paleotopographic surfaces on the Ione Formation, northern San Joaquin Valley, California in Singer, M. J., ed, Soil development, geomorphology, and Cenozoic history of the northeastern San Joaquin Valley and adjacent areas, California: Davis, Univ. Calif. Press, Guidebook for Joint Field Session, Soil Sci. Soc. America-Geol. Soc. America, p. 319.328.

Evernden, J. F., Savage, D. E., Curtis, G. H., and James, G. T., 1964, Potassiumargon dates and the Cenozoic mammalian chronology of North America: Am. Jour. Sci., v. 262, p. 145-198.

Foss, C. D., 1972, A preliminary sketch of the San Joaquin Valley stratigraphic framework, in Geology and oilfields, west side, central San Joaquin Valley: Guidebook, Am. Assoc. Petroleum Geologists, Pacific Section, p. 40-50.

Frink, J. W., and Kues, H. A., 1954, Corcoran clay, a Pleistocene lacustrine deposit in the San Joaquin Valley, California: Am. Assoc. Petroleum Geologists Bull, v. 38 , p. 2353-2371.

Gales, H. S., Piper, A. M., and Thomas, H. E., 1939, Geology of the Mokelumne area, California, in Piper, A. M., Gale, H. S., Thomas, H. E., and Robinson, T. W., Geology and ground-water hydrology of the Mokelumne area, California: U.S. Geol. Survey Water-Supply Paper 780, p. 14-100.

Gillam, M. L., 1974, Contact relations of the Ione and V alley Springs Formations in the Buena Vista area, Amador County, California: Stanford Univ., Stanford, Calif., M. S. thesis, 180 p.

Hansen, R. O., and Begg, E. L., 1970, Age of Quaternary sediments and soils in the Sacramento area, California by uranium and actinium series dating of vertebrate fossils: Earth Planetary Sci. Let. v. 8, p. 411-419.

Harden, J. W., and Marchand, D. E., 1977, The soil chronosequence of the Merced River area, in Singer, M. J., ed., Soil development, geomorphology, and Cenozoic history of the northeastern San Joaquin Valley and adjacent areas, California: Davis, Univ. Calif. Press, Guidebook for Joint Field Session, Soil Sci. Soc. America-Geol. Soc. America, p. 22-38.

1980, Quaternary stratigraphy and interpretation of soil data from the Auburn, Oroville, and Sonora areas along the Foothills fault system, western Sierra Nevada, California: U.S. Geol. Survey open-file report 80-305, 57 p.

Hays, J. D., Imbrie, J., and Shackleton, N. J., 1976, Variations in the earth's orbit: 
Pacemaker of the ice ages: Science, v. 194, no. 4270, p. 1121-1132.

Helley, E. J., 1967, Sediment transport in the Chowchilla River basin: Mariposa, Madera, and Merced Counties, California: California Univ., Berkeley, Ph.D. thesis, $153 \mathrm{p}$.

Hubbs, C. L., and Bien, G. S., 1967, La Jolla natural radiocarbon measurements V: Am. Jour. Sci. Radiocarbon supp., v. 9, p. 287-288.

Huber, N.K., 1977, Silica content of some late Cenozoic volcanic rocks from the southern Sierra Nevada, California-applications as a correlation tool: U.S. Geol. Survey open-file report 77-755, 42 p.

Hudson, F. S., 1960, Post-Pliocene uplift of the Sierra Nevada, California: Geol. Soc. America Bull., v. 71, p. 1547.1575.

Huntington, G. L., 1971, Soil survey of the eastern Fresno area, California: U.S. Dept. Agriculture, 323 p.

Ives, P. C., Levin, Betsy, Oman, C. L., and Rubin, Meyer, 1967, U.S. Geological Survey radiocarbon dates IX: Radiocarbon, v. 9, p. 514.

Janda, R. J., 1965, Quaternary alluvium near Friant, California: Internat. Assoc. Quaternary Research Guidebook for Field Conference I, northern Great Basin and California, p. 128-133.

1966, Pleistocene history and hydrology of the upper San Joaquin River, California: California Univ., Berkeley, Ph.D. thesis, 425 p.

Janda, R. J., and Croft, M. G., 1967, The stratigraphic significance of a sequence of noncalcic brown soils formed on the Quaternary alluvium of the northeastern San Joaquin Valley, California, in International Association Quaternary Research, Quaternary Soils: Internat. Assoc. Quaternary Research, VII Cong., Reno, Nev., Proc., v. 9, p. 158-190.

MacDonald, G. A., 1941, Geology of the western Sierra Nevada between the Kings and San Joaquin Rivers, California: California Univ. Pub's. Geol. Sci., v. 26, p. 215-286.

Mankinen, E. A., and Dalrymple, G. B., 1979, Revised geomagnetic polarity time scale for the interval 0-5 m.y. B. P.: Jour. Geophys. Research, v. 84, no. B2, p. $615 \cdot 626$.

Marchand, D. E., 1976a, Preliminary geologic maps showing Quaternary deposits of the northern Merced area, eastern San Joaquin Valley, Merced and Stanislaus Counties, California: U.S. Geol. Survey Open-File Report 76-836, scale 1:24,000. $1976 \mathrm{~b}$, Preliminary geologic maps showing Quaternary deposits of the Merced area, eastern San Joaquin Valley, Merced County, California: U.S. Geol. Survey Open-File Report 76-837, scale 1:24.000.

1976c, Preliminary geologic maps showing Quaternary deposits of the southern Merced area, eastern San Joaquin Valley, Merced and Madera Counties, California: U.S. Geol. Survey Open-File Report 76-838, scale 1:24,000. 1976d, Preliminary geologic maps showing Quaternary deposits of the Chowchilla area, eastern San Joaquin Valley, Merced and Madera Counties, California: U.S. Geol. Survey Open-File Report 76-839, scale 1:24,000.

1976 e, Preliminary geologic maps showing Quaternary deposits of the Daulton area, eastern San Joaquin Valley, Madera County, California: U.S. Geol. Survey Open.File Report 76-840, scale 1:24,000.

1976f, Preliminary geologic maps showing Quaternary deposits of the Madera area, eastern San Joaquin Valley, Madera and Fresno Counties, California: U.S. Geol. Survey Open-File Report 76-841, scale 1:24,000.

$1976 \mathrm{~g}$, Late Cenozoic stratigraphy and history of the northeastern San Joaquin Valley: Some early results of a regional study [abs.]: Geol. Soc. America, Cordilleran Sec., Ann. Mtg. 72d Abs. with Programs, v. 8, no. 3, p. 393-394. 
1977, The Cenozoic history of the San Joaquin Valley and the adjacent Sierra Nevada as inferred from the geology and soils of the eastern San Joaquin Valley in Singer, M. J., ed., Soil development, geomorphology, and Cenozoic history of the northeastern San Joaquin Valley and adjacent areas, California: Davis, Univ. Calif. Press, Guidebook for Joint Field Session, Soil Sci. Soc. America and Geol. Soc. America, p. 39-50.

Marchand, D. E., and Harden, Jennifer, 1976, Soil chronosequences, northeastern San Joaquin Valley, California [abs.]: Am. Quaternary Assoc., Abs. Fourth Bienn. Mtg., Tempe, Ariz., p. 110.

Nikiforoff, C. C., 1941, Hardpan and microrelief in certain soil complexes of California: U.S. Dept. Agriculture Tech. Bull. 745, p. 45.

Packer, D. R., McCleary, J. R., Cherven, V. B., and Blum, R. L., 1977, Paleomagnetic investigations of the Turlock Lake Formation at the type section, in Singer, M. J., ed., Soil development, geomorphology, and Cenozoic history of the northeastern San Joaquin Valley and adjacent areas, California: Davis, Univ. California Press, Guidebook for Joint Field Session, Soil Science Soc. AmericaGeol. Soc. America, p. 267-276.

Rosholt, J. N., 1978 Uranium-trend dating of alluvial deposits in Extended abstracts of fourth international conference on geochronology, cosmochronology and isotope geology: U.S. Geol. Survey open-file report 78-701, p. 360-362.

Sarna-Wojcicki, A. M., Bowman, H. R., and Russell, P. C., 1979, Chemical correlation of some late Cenozoic tuffs of northern and central California by neutron activation analysis of glass and comparison with $x$-ray fluorescence analysis: U.S. Geol. Survey Prof. Paper 1147, 15 p.

Sarna-Wojcicki, A. M., Bowman, H. R., Meyer, C. E., Russell, P. C., Asaro, Frank, Michael, Helen, Rowe, J. J., and Baedecker, P. A., 1980, Chemical analyses, correlations, and ages of late Cenozoic tephra units of east-central and southern California: U.S. Geol. Survey Open-File Report 80-231, 55 p.

Shlemon, R. J., 1967a, Landform-soil relationships in northern Sacramento County, California: California Univ., Berkeley, Ph.D. thesis.

$1967 \mathrm{~b}$, Quaternary geology of northern Sacramento County, California: Geol. Soc. Sacramento Ann. Field Trip Guidebook, $60 \mathrm{p}$.

1971, The Quaternary deltaic and channel system in the central Great Valley, California: Annals As8oc. Am. Geographers, v. 61, no. 3, p. 427-440.

1972, The lower American River area, California: A model of Pleistocene landscape evolution: Assoc. Pacific Coast Geographers Yearbook, v. 34, p. 62-86.

Shlemon, R. J., and Begg, E. L., 1972, A Holocene soil-landscape chronology, southwestern Sacramento Valley, California, in Adams, W.P., and Helleiner, F. M., eds., International geography: Internat. Geog. Cong., 22d, Montreal, Univ. Toronto Press, p. 277-279.

Shlemon, R. J., and Begg, E. L., 1975, Late Quaternary evolution of the SacramentoSan Joaquin Delta, California in Quaternary Studies (R. P. Suggate and M. M. Cresswell, eds.): the Royal Society of New Zealand, Wellington, p. 259-266.

Soil Survey Staff, 1975, Soil taxonomy: U.S. Dept. Agriculture Soil Conserv. Service, Agriculture Handb. no. 346, 754 p.

Uhich, R., and Stromberg, L. K., 1962, Soil survey of the Madera area, California: U.S. Dept. Agriculture Soil Survey Ser. 1951, no. 11, 155 p.

Wagner, Hugh, 1976, A new species of Pliotaxidea (Mustelidae: Carnivora) from California: Jour. Paleontology, v. 50, no. 1, p. 107-127. 

GPO $\quad 789-035 / 52$ 


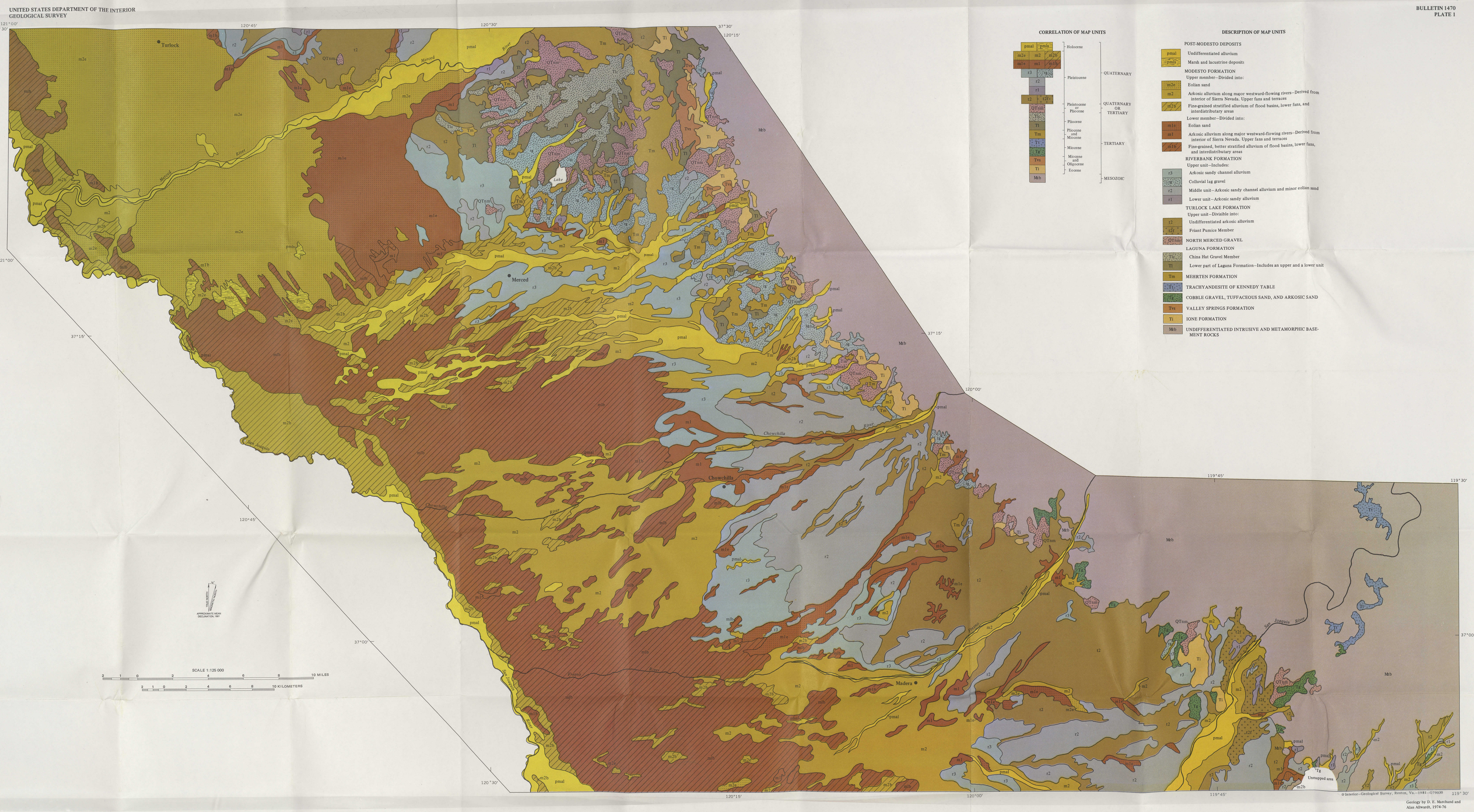



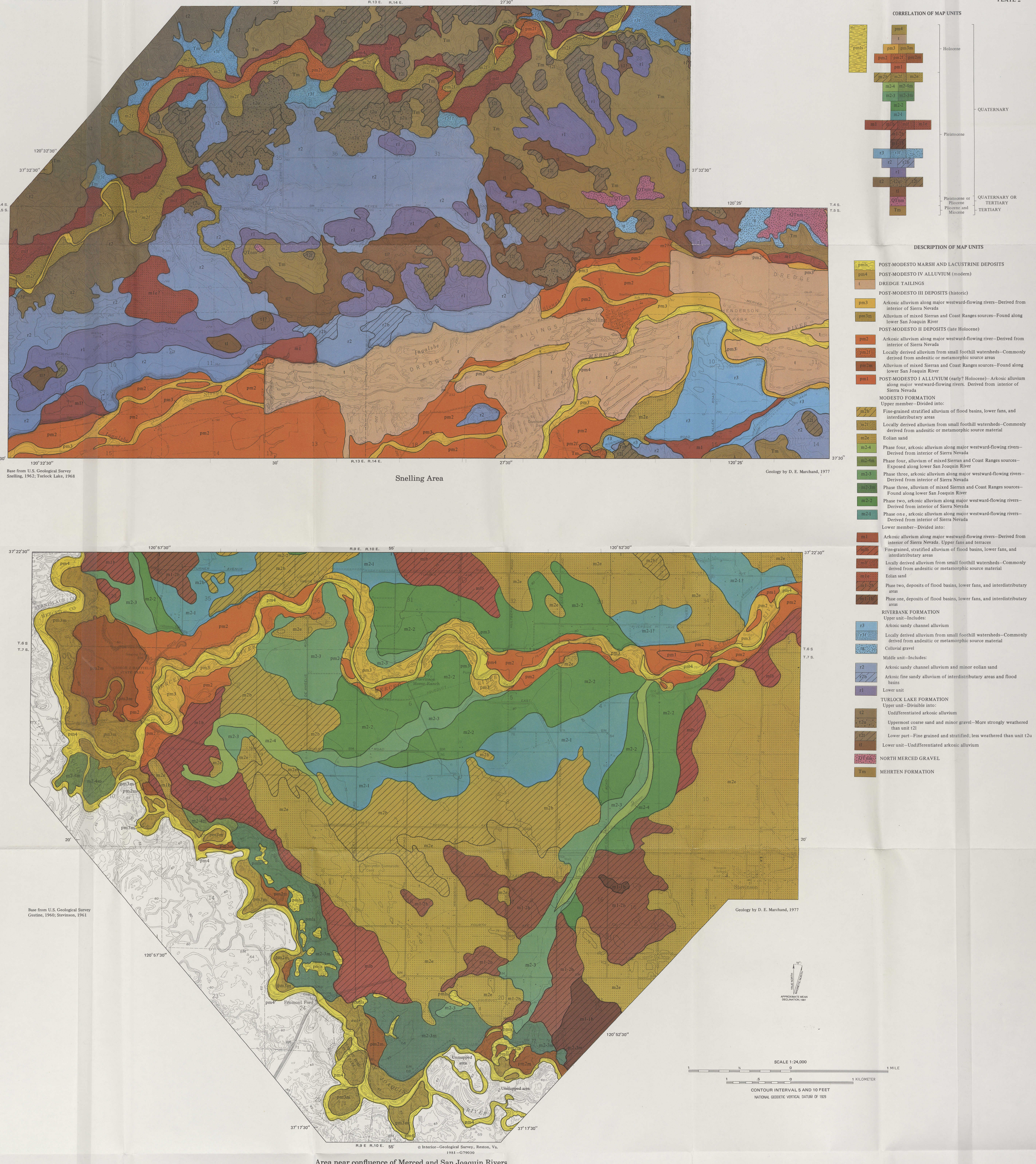

GEOLOGIC MAP OF THE SNELLING AREA AND THE AREA NEAR THE CONFLUENCE OF THE MERCED AND SAN JOAQUIN RIVERS, MERCED COUNTY, CALIFORNIA 


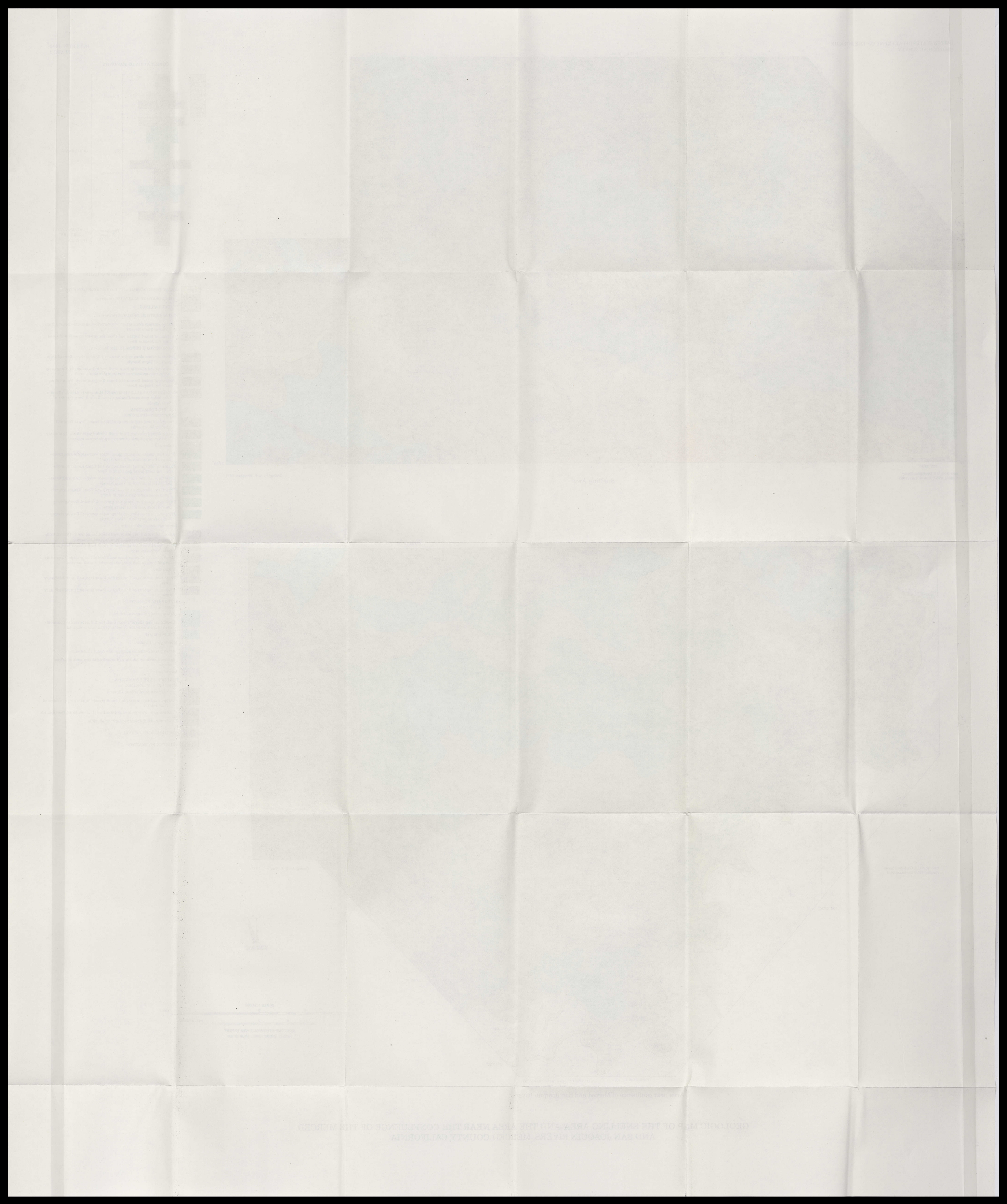



